WSRC-TR-2003-00556, Rev. 0

Key Words: Tank Closure

Hanford ATCD

Hanford Grout

Retention: Permanent

\title{
Grout Placement and Property Evaluation for Closing Hanford High-Level Waste Tanks - Scale-Up Testing
}

\author{
C. A. Langton,* J. R. Harbour,* D. H. Miller,* W. L. Mhyre, ${ }^{+}$C. N. Shramek, ${ }^{+}$ \\ J. Carroll,** E. Johnson,** and A. L. Furgeson** \\ * Savannah River National Laboratory \\ Westinghouse Savannah River Company \\ Aiken, SC 29808 \\ ${ }^{+}$Washington Group Quality Programs \\ Aiken, SC 29808 \\ **Bechtel Savannah River Company \\ Aiken, SC 29808
}

December 15, 2003

Westinghouse Savannah River Company

Savannah River Site

Aiken, SC 29808

Prepared for the U.S. Department of Energy Under

Contract Number DE-AC09-96SR18500

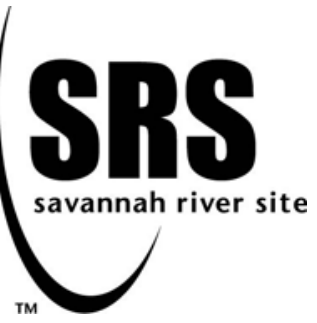


This document was prepared in conjunction with work accomplished under Contract No. DE-AC09-96SR18500 with the U. S. Department of Energy.

\section{DISCLAIMER}

This report was prepared as an account of work sponsored by an agency of the United States Government. Neither the United States Government nor any agency thereof, nor any of their employees, makes any warranty, express or implied, or assumes any legal liability or responsibility for the accuracy, completeness, or usefulness of any information, apparatus, product or process disclosed, or represents that its use would not infringe privately owned rights. Reference herein to any specific commercial product, process or service by trade name, trademark, manufacturer, or otherwise does not necessarily constitute or imply its endorsement, recommendation, or favoring by the United States Government or any agency thereof. The views and opinions of authors expressed herein do not necessarily state or reflect those of the United States Government or any agency thereof.

This report has been reproduced directly from the best available copy.

Available for sale to the public, in paper, from: U.S. Department of Commerce, National Technical Information Service, 5285 Port Royal Road, Springfield, VA 22161, phone: (800) 553-6847, fax: (703) 605-6900

email: orders@ntis.fedworld.gov

online ordering: http://www.ntis.gov/help/index.asp

Available electronically at http://www.osti.gov/bridge

Available for a processing fee to U.S. Department of Energy and its contractors, in paper, from: U.S. Department of Energy, Office of Scientific and Technical Information, P.O. Box 62, Oak Ridge, TN 37831-0062,

phone: (865)576-8401,

fax: (865)576-5728

email: $\underline{\text { reports@ adonis.osti.gov }}$ 
This page was intentionally left blank 
WSRC-TR-2003-00556, Rev. 0

December 15, 2003

Page ii

\section{TABLE OF CONTENTS}

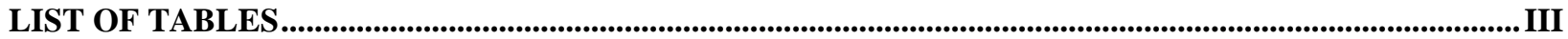

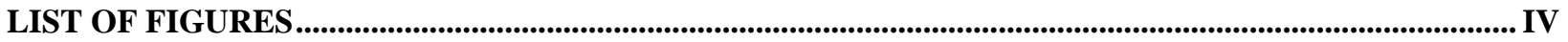

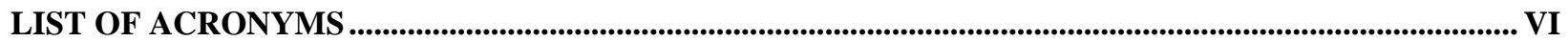

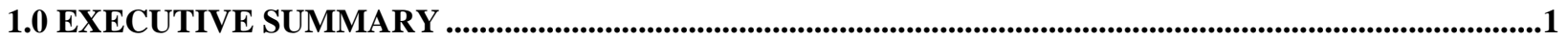

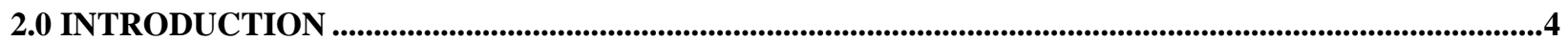

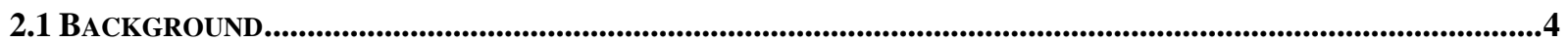

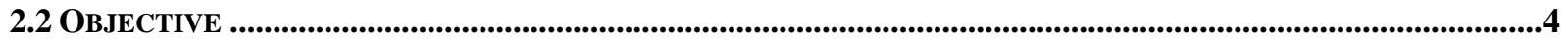

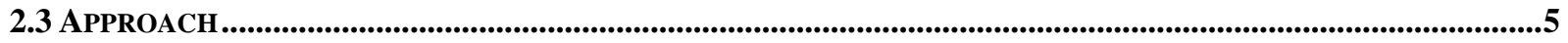

3.0 EXPERIMENTAL METHODS ........................................................................................................................6

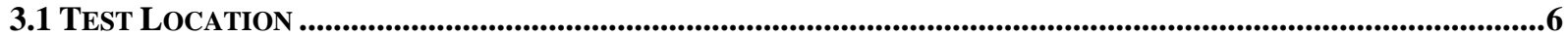

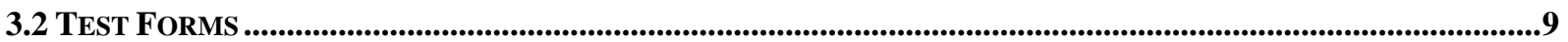

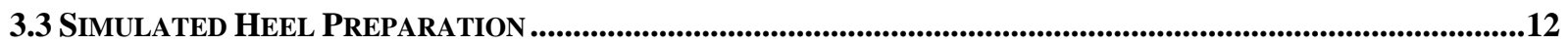

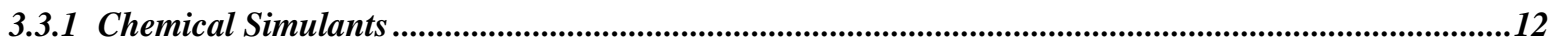

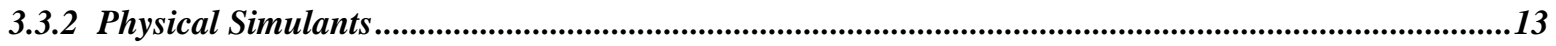

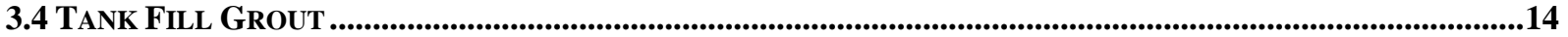

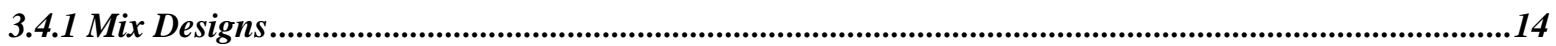

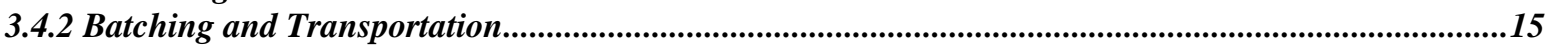

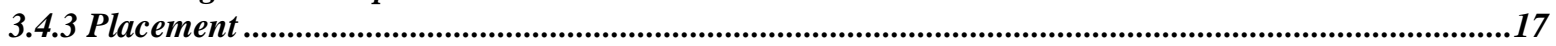

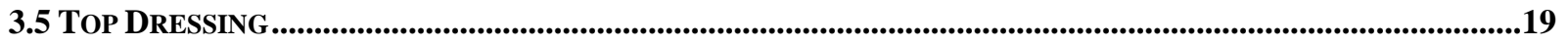

3.6 EQUIPMENT AND RISER FILL GROUT ..............................................................................................................19

3.6.1 Grout Materials..............................................................................................................................................19

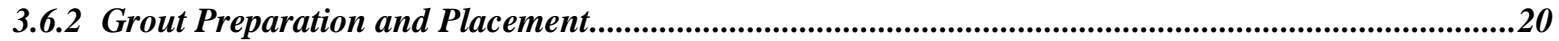

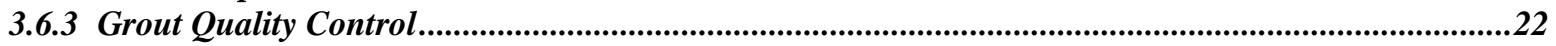

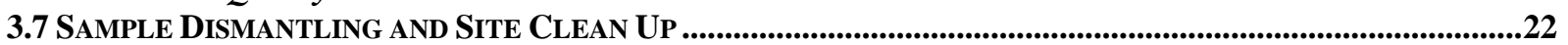

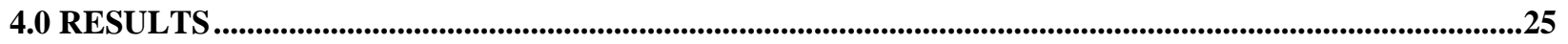

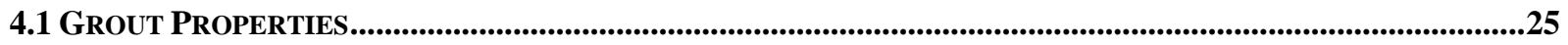

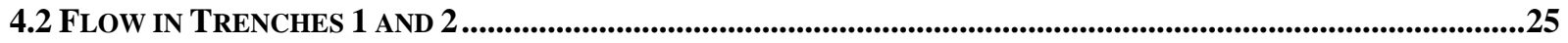

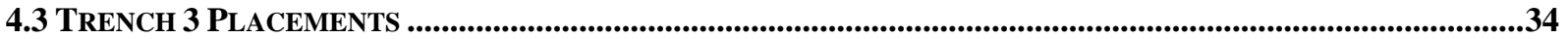

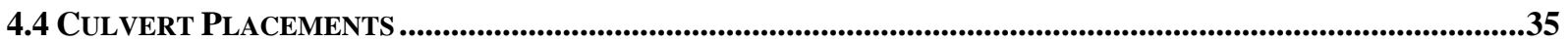

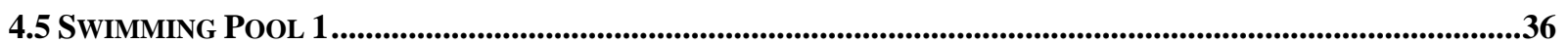

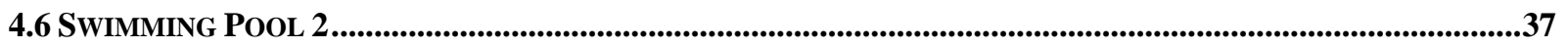

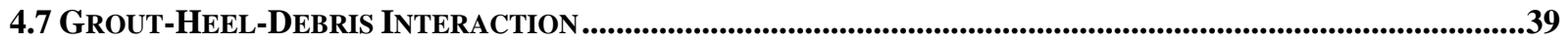

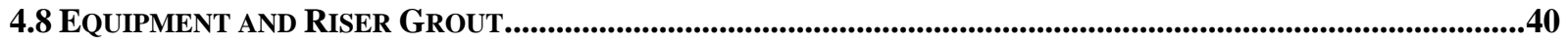

5.0 DISCUSSION.....................................................................................................................................................42

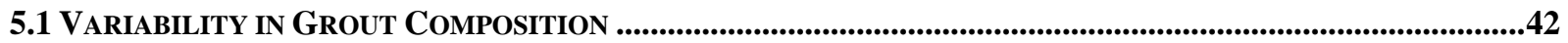

5.2 CoMPARISON OF BENCH SCALE AND FIELd GROUT PROPERTIES ..........................................................43

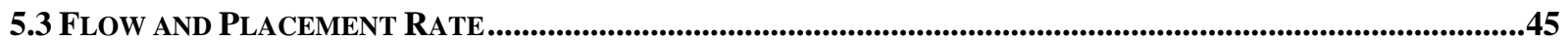

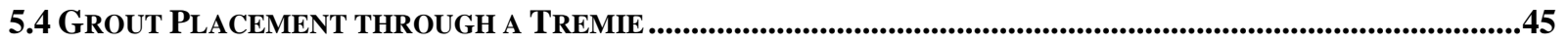

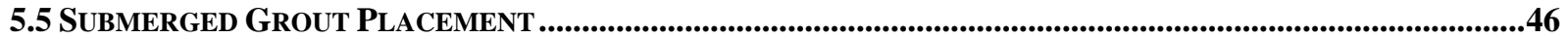

5.6 GROUT SEGREGATION .................................................................................................................................46

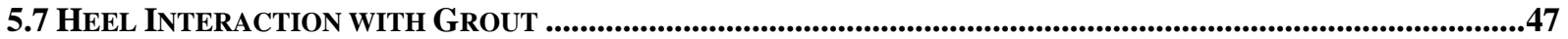

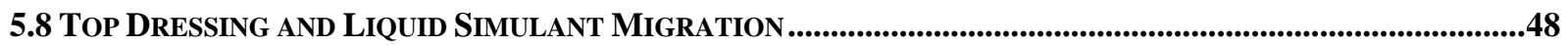

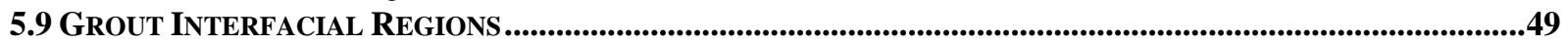

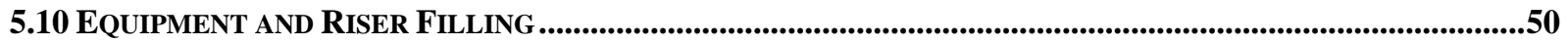

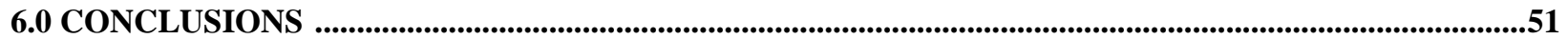

7.0 RECOMMENDATIONS .....................................................................................................................................53

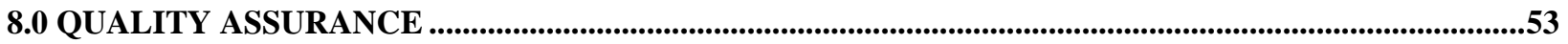

9.0 REFERENCES 


\section{LIST OF TABLES}

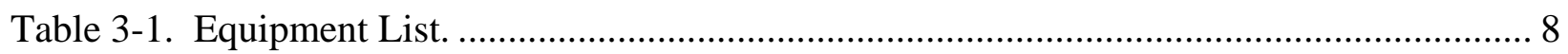

Table 3-2. Summary of Forms Used in Scale-up Testing..................................................... 9

Table 3-3. Simulated C-106 Heel Ingredients. ................................................................... 12

Table 3-4. Simulated C-200 Heel Ingredients. ...................................................................... 12

Table 3-5. Hanford tank closure grout formulations for a 15 inch flow per ASTM D-6103. .... 14

Table 3-6. SRS equilavent grout formulations used for scale-up testing for a 15 inch flow per

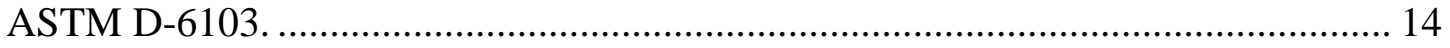

Table 3-7. Ingredients and amounts per cubic yard for the mixes placed in the scale up tests. .. 16

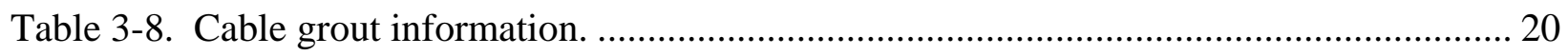

Table 4-1. Property measurements for mixes prepared for the scale-up test............................ 26

Table 4-2. Water and admixture contents of the grouts prepared for the scale-up testing. ......... 27

Table 4-3. Placement results for the scale up test.................................................................. 28

Table 4-4. Trench 1 pour thickness and surface elevation data.............................................. 29

Table 4-5. Trench 2 pour thickness and surface elevation data................................................ 29

Table 4-6. Cable grout mix proportions and properties.................................................... 40

Table 5-1. Variation in actual versus design weights for ingredients in 15 grout batches. ......... 42

Table 5-2. Physical Properties of the Structural Grouts (HRG2 and SRG2) Prepared in the Bench-Scale [9] and Scale-Up Tests................................................................... 43

Table 5-3. Physical Properties of the Stabilization Grouts (HRG4 and SRG4) Prepared in the

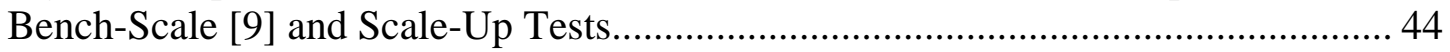

Table 5-4. Physical Properties of the Capping Grouts (HRG9 and SRG9) Prepared in the Bench-

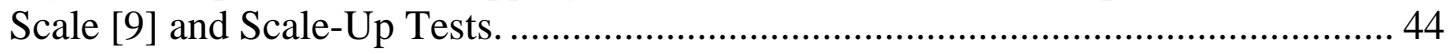

Table 5-5. Times Between Pours in Swimming Pool 2 (no dry grout addition). ....................... 49

Table 5-6. Times Between Placements in Swimming Pool 1.................................................. 50 


\section{LIST OF FIGURES}

Figure 3-1. Burma Road Landfill test location for the Hanford grout scale-up tests. .................... 7

Figure 3-2. Trench form construction................................................................................. 10

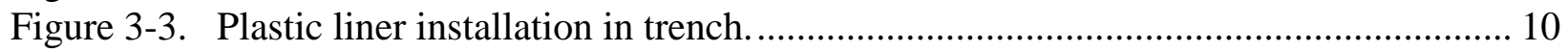

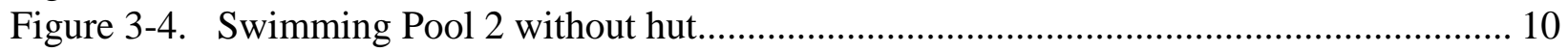

Figure 3-5. Plastic hut around Swimming Pool 1 and and pump truck ..................................... 10

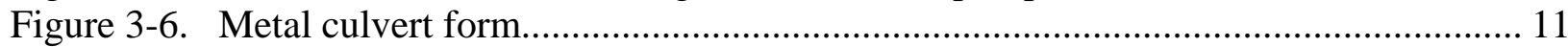

Figure 3-7. Metal culvert form (inside). .............................................................................. 11

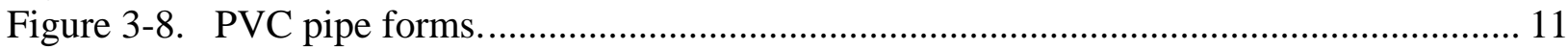

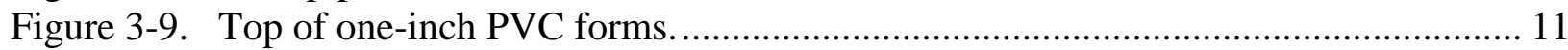

Figure 3-10. Photograph of set up used to prepare simulated tank heels. ................................... 13

Figure 3-11. Physical simulants in Pool 1............................................................................ 13

Figure 3-12. Physical and chemical simulants in Pool 2. (Simulated supernate was yellow.)... 13

Figure 3-13. Photograph of central batch plant used to prepare grout mixes................................ 15

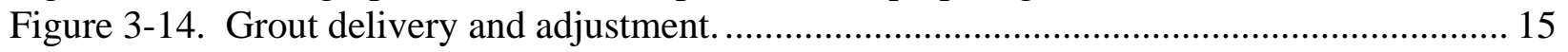

Figure 3-15. Photograph of flow test. .................................................................................... 15

Figure 3-16. Gravity pour from a concrete truck chute into a trench form. .................................. 17

Figure 3-17. Gravity pour into a trench form from a concrete truck. ........................................ 17

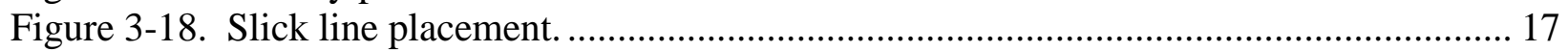

Figure 3-19. Attempted boom truck placement .............................................................................. 17

Figure 3-20. Placement into Pool 1 through a 5 inch steel pipe. ................................................... 18

Figure 3-21. Placement into Pool 2 through a 5 inch steel pipe. ................................................. 18

Figure 3-22. Placement through a 5 inch metal line with a flexible tremie at the discharge....... 18

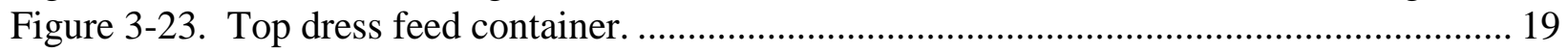

Figure 3-24. Top dress application from the top of the hut. .......................................................... 19

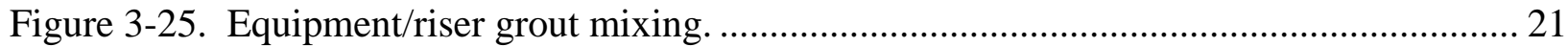

Figure 3-26. Equipment/riser fill grout flow test........................................................................... 21

Figure 3-27. Equipment/riser grout conveyance to top of the form. ............................................ 21

Figure 3-28. Equipment/riser grout funnel hopper which contained a screen to remove lumps

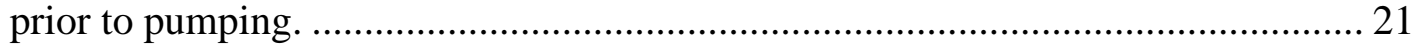

Figure 3-29. Excavation of grout placed in trench forms. ........................................................... 22

Figure 3-30. Size reduction of the grouts poured in the trench forms after curing for 5 to 10

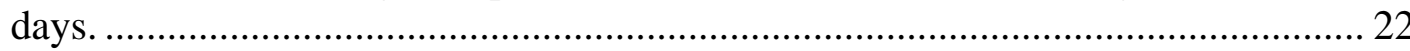

Figure 3-31. Demolition of the pool 1 monolith 5 days after the final Capping Grout pour...... 23

Figure 3-32. Demolition of the pool 2 monolith 5 days after the final Capping Grout pour........ 23

Figure 3-33. Core sampling of Pool 2.................................................................................... 24

Figure 3-34. Sampling Pool 2 with electric chisel.................................................................... 24

Figure 4-1. Schematic of Trench 1 illustrating the thickness of each placement relative to the discharge point.................................................................................................... 30

Figure 4-2. Schematic of Trench 2 illustrating the thickness of each placement relative to the discharge point. .......................................................................................................... 31

Figure 4-3. Stabilizing grout in Trench 1 immediately after placement........................................ 32

Figure 4-4. Structural grout in Trench 1 immediately after placement. ....................................... 32

Figure 4-5. Capping grout in Trench 1 immediately after placement.......................................... 32

Figure 4-6. Capping grout in Trench 1 immediately after placement........................................... 32 
Figure 4-7. Stabilizing grout being placed in Trench 2 through a 5 inch slick line................... 33

Figure 4-8. Capping grout in Trench 2 immediately after placement.................................... 33

Figure 4-9. Slick line cleaning. Grout spray from pressurizing the line................................ 33

Figure 4-10. "Pig catcher" for catching the rubber ball used to clean the slick line. ................. 33

Figure 4-11. Capping grout, SRG9, discharged into Trench 3 from a two-foot drop through a tremie.

Figure 4-12. Capping grout, SRG9, discharged into Trench 3 from a ten-foot drop.................. 34

Figure 4-13. Capping grout placement in Culvert 1 ....................................................... 35

Figure 4-14. Capping grout placement in Culvert 2. .................................................... 35

Figure 4-15. Stabilizing grout and C-106 simulated heel and debris, Pool 1.......................... 36

Figure 4-16. Stabilization grout as covering solid simulated heel and displacing supernate

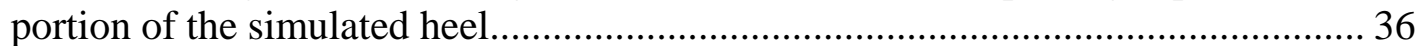

Figure 4-17. Stabilizing Grout (layer 2) placed on dry grout and C-106 simulanted heel. ......... 37

Figure 4-18. Top dressing over the second Stabilization Grout layer. ..................................... 37

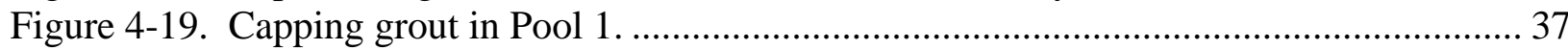

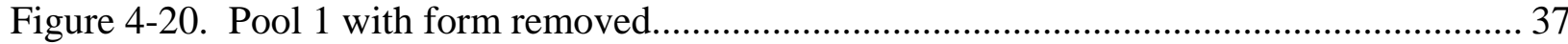

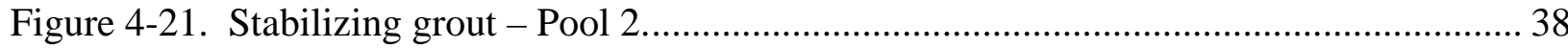

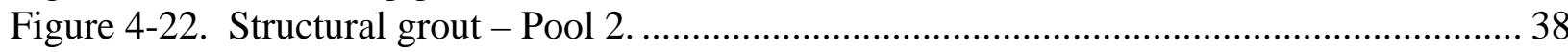

Figure 4-23. Capping grout - Pool 2. .......................................................................... 38

Figure 4-24. Pool 2 after the form was removed, 5 days after final pour................................. 38

Figure 4-25. Pool 1, $2^{\text {nd }}$ top dressing, thin dark gray layer, between the top of the $2^{\text {nd }}$ Stabilization grout and Structural grout.......................................................... 39

Figure 4-26. Debris in Pool 2 filled with Stabilization grout (bottom-side)............................. 39

Figure 4-27. Simulated debris in Pool 1 filled and covered with Stabilization grout. (Marker for

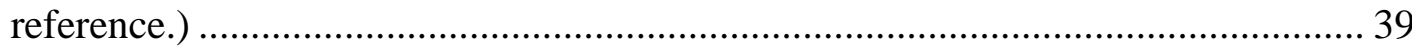

Figure 4-28. Simulated debris in Pool 2 filled and covered with Stabilization grout................. 39

Figure 4-29. Sections of a one-inch PVC pipe (20 ft long) filled from the top with Masterflow 1205 grout.

Figure 4-30. One-inch PVC pipe with copper wires filled with Masterflow 1205 grout pumped through $3 / 8$ inch tube.

Figure 4-31. One-inch PVC pipe (20 foot section) filled with Masterflow 816 grout pumped

Figure 4-32. One-inch PVC pipe (20 foot section) filled with Masterflow1341 grout pumped

through a $3 / 8$ inch tube. ................................................................................ 41

Figure 4-33. One-inch PVC pipe (60 feet long) filled with Masterflow 1205 grout.................. 41

Figure 4-34. Section of 60-foot PVC pipe filled with masterflow 1205 gout. .......................... 41 


\section{LIST OF ACRONYMS}

$\begin{array}{ll}\text { AHA } & \text { Automated Hazarads Analysis } \\ \text { ASTM } & \text { American Society for Testing and Materials } \\ \text { ATCD } & \text { Accelerated Tank Closure Demonstration } \\ \text { C3T } & \text { Cleanup, Constraints, and Challenges Team } \\ \text { CH2M HILL } & \text { CH2M HILL Hanford Group } \\ \text { CSRA } & \text { Central Savannah River Area } \\ \text { cyd } & \text { Cubic yard } \\ \text { DIW } & \text { Deionized water } \\ \text { DOE } & \text { U. S. Department of Energy } \\ \text { EA } & \text { Environmental Assessment } \\ \text { EIS } & \text { Environmental Impact Statement } \\ \text { GGBFS } & \text { Ground Granulated Blast-Furnace Slag } \\ \text { HLW } & \text { High-Level Waste } \\ \text { HRG } & \text { Hanford reducing grout } \\ \text { ROD } & \text { Record of Decision } \\ \text { SOW } & \text { Statement of Work } \\ \text { SRG } & \text { Savannah River Reducing Grout } \\ \text { SRS } & \text { Savannah River Site } \\ \text { SRNL } & \text { Savannah River National Laboratory } \\ \text { TTQAP } & \text { Task Technical and Quality Assurance Plan } \\ \text { WGI } & \text { Washington Group International } \\ \text { WSRC } & \text { Westinghouse Savannah River Company, LLC } \\ \end{array}$




\subsection{EXECUTIVE SUMMARY}

Hanford has 149 single-shell HLW tanks that were constructed between 1943 and 1964. Many of these tanks have leaked or are suspected of leaking HLW into the soil above the ground water. Consequently, a major effort is ongoing to transfer the liquid portion of the waste to the 28 newer, double-shell tanks.

Savannah River National Laboratory (SRNL) was tasked to develop grout formulations for the three-layer closure concept selected by CH2M HILL for closing Tank C-106. These grout formulations were also evaluated for use as fill materials in the next six tanks scheduled to be closed: C-201, C-202, C-203, C-204, S-102, and S-112. The overall scope consisted of both bench-scale testing to confirm mix designs and scale-up testing to confirm placement properties.

This report provides results of the scale-up testing for the three-phase tank closure strategy. It also contains information on grouts for equipment and riser filling. The three-phase fill strategy is summarized as follows:

- Phase I fill encapsulates and minimizes dispersion of the residual waste in the tank. This fill is referred to as the Stabilization Layer and consists of the Stabilization Grout.

- The Phase II fill provides structural stability to the tank system and prevents subsidence. It is referred to as the Structural Layer and consists of the Structural Grout.

- A final Phase III fill consists of a grout designed to provide protection against intrusion and is referred to as the Capping Layer or Capping Grout.

The scale-up testing was performed in November 2003 at the SRS. The testing consisted of: placing grout in three trenches ( $80 \mathrm{ft}$ long), two swimming pools (15 ft in diameter), and two culverts ( $2 \mathrm{ft}$ in diameter and $10 \mathrm{ft}$ tall) and recording flow, heel-grout interactions, and other general observations. Placements were accomplished by directly dumping the fill from the concrete delivery truck or by discharging into a pump hopper and pumping through a five-inch carbon steel slick line with and without a tremie attached to the end of the line. Two dry grout (top dressing) placements were made into a swimming pool form contained in a plastic hut. In addition, three commercially available cable grouts were either poured or pumped into $20-\mathrm{ft}$ sections of 1-inch diameter PVC pipe to simulate equipment stabilization.

One of the major objectives of this scale-up testing was to determine whether the grout could flow from one end of a tank 75 feet in diameter to the other end. This is potentially important for Tank C-106 if filling is limited to use of near-edge, side risers which would result in a flow distance of up to 75 feet. The scale-up testing indicated that, for very high placement rates, greater than $300 \mathrm{cyd} / \mathrm{hr}$, the stabilization and structural grouts were capable of flowing $75 \mathrm{ft}$ and were self-leveling over this distance.

At lower placement rates, $60-80 \mathrm{cyd} / \mathrm{hr}$, these grouts flowed $75 \mathrm{ft}$ but were no longer selfleveling. At the lower pour rates, the tank fill grouts were not self-leveling over 75 feet. These results indicate that 75 -foot diameter tanks should be filled from a center riser or from multiple (at least 2) evenly spaced center risers. Filling 75-foot diameter tanks from only one side riser is not recommended. 
WSRC-TR-2003-00556, Rev. 0

December 15, 2003

Page 2 of 55

The scale-up testing required many small batches of material. Batching and delivery available for this testing were limited to central mixing and trucking to the test site, respectively. Because the tank fill grouts are very fluid after addition of all of the water and admixtures, final mix adjustments (water and admixture additions) to fluidify the grouts were made at the field site. For mixes with the design amount of admixture, 9\% less water on average, was required in the field compared to the amount determined in the bench-scale study. For mixes with 1.5 times the design amount of admixture, $4 \%$ more water on average was required than the amount determined from the bench scale study. The reasons for these differences are unclear, but wash water left in the trucks or variability in the free water in the sand could account for the discrepancy. This demonstrates the variability encountered in field and scaleup testing and the importance of including the provision for mix adjustments under operating conditions. It also demonstrates the need to conduct scale-up testing at the 8 to 10 cubic yard batch size using Hanford materials to finalize the design mixes and to specify the maximum amounts of water and admixture.

Information was obtained on the interaction of the tank fill/grout with the simulated tank heel (sludge, supernate) and equipment/debris from the multi-layer swimming pool tests. The Stabilization Grout covered and encapsulated the solid portion of the tank heel (sludge) and debris. Voids in the debris were filled with grout. The liquid portion of the heel (supernate) was displaced by the grout. Successive grout pours continued to displace the liquid portion of the simulant upward.

To eliminate the upward displacement of the supernate, a top dressing consisting of dry grout (cement, slag, and fly ash powders) was applied in one of the swimming pool experiments. Top dressing was effective in solidifying the supernate (converting it from a liquid to a solid) and therefore is an effective method of isolating the contaminants dissolved in the supernate such as Tc-99. The water in the supernate reacted with the cement (slag and fly ash) in the top dressing to form solid hydrated phases. Some of the supernate was also incorporated into the grout by mixing and sorption, i.e., the grout was able to take a small amount of additional water (supernate) without segregation.

The top dressing materials coated all inner surfaces during the application. Consequently, the top dressing should coat the inner walls of the HLW tanks and any equipment within the tank. The dust generated from the application of the top dressing settled within 12 hours.

The swimming pools were dismantled five days after the Capping Grout was placed. The layered monoliths displayed significant strength as demonstrated by the difficulty encountered in breaking them apart. A dozer and heavy-duty forklift were unsuccessful in turning over the monoliths. Both monoliths were repeatedly lifted on one side and dropped several (5-6) feet without breaking. Eventually, the dozer rammed the monoliths to break them horizontally. The horizontal fractures were through the top dressing in pool 1 (C-106 simulated waste) and along the Stabilization Grout- Structural Grout interface in pool 2 (average C-200 series tank simulated waste).

To define the appropriate drop height, two experiments were performed to evaluate segregation of the Structural Grout as a function of drop height. The mix used in this test had a high water content and a high flow (at the upper end of the allowable range). However, bleed water was 
WSRC-TR-2003-00556, Rev. 0

December 15, 2003

Page 3 of 55

observed in the sample tested in the laboratory after the pour was already made. Segregation in the form of bleed water was observed in both experiments, when the grout was dropped from 10 feet and from 2 feet. Consequently this test failed to provide the expected information.

Vibration as a means of enhancing flow was also tested on the Structural Grout pours made in an 80-foot trench. Vibration immediately caused segregation and produced bleed water without significantly enhancing flow. Consequently, vibration is not recommended for very fluid mixes (flows greater than about 12 inches).

Another experiment was performed to evaluate the effects of pumping the Capping Grout against a head pressure of up to 8 feet of grout. This situation will be encountered in the upper regions of the tank. Two-foot diameter culverts were used as vertical forms. Capping Grout was pumped through a 5-inch diameter slick line positioned about six inches from the bottom of each culvert. The flow for the grout placed in the first culvert was the target value. The pumping action introduced a large amount of air, which migrated through the grout causing agitation that produced a large amount of bleed water. Consequently, the second test used a grout with a lower flow because an extra dose, 1.5X, of the admixture blend (ADVA Flow plus Kelco-Crete) and less water was used to reduce segregation. (The flow distance in the top of the tank will be somewhat less than in the rest of the tank due to the dome shape. Further testing is required to determine whether tank fill grouts with reduced flows are capable of filling the actual domes.) Segregation was completely eliminated by the extra admixture, placement properties were retained, and placement against 8 feet of grout head was successfully demonstrated.

Finally, to simulate equipment stabilization, three commercially available cable grouts were used to fill one-inch diameter vertical PVC pipes, 20 feet long and capped at the bottom. Filling was accomplished by pouring through a funnel and by pumping through a 3/8-inch tube inserted to the bottom of the pipe. One pipe filled by pumping contained additional electrical wire obstructions. All of these tests were highly successful. Subsequent dissection of PVC pipes indicated that they were completely filled even around the small electrical wire obstructions. 


\subsection{INTRODUCTION}

\subsection{Background}

The scale-up testing described in this report was intended to address placement issues identified by CH2M HILL [1]. Concerns included: grout placement at various riser locations (center, off center, near tank wall) and riser diameters, grout flow distance, grout placement rate, dome filling, riser filling, and physical mixing of grout and tank heel material and debris. The scale up-test was performed as part of the Scope of Work for Interoffice Work Order No. MOSRLE81 [2].

Tank specific information from Tanks C-106, C-201 to 204, S-102 and S-112 was used to develop the scale-up test program. Tank riser and accessibility information and additional information to develop a test scenario for riser/equipment stabilization were provided by CH2M HILL [3].

The Scale-up testing was performed per the TTP/QAP approved by CH2M HILL [4]. The three-layer concept identified by CH2M HILL was applied to the scale-up testing. Since the testing was performed at SRS and involved a relatively large amount of grout (about 90 cubic yards), materials locally available at SRS (cement, slag, fly ash and concrete sand) were used for the scale-up testing. Equivalency of the SRS grouts and Hanford Phase 1, 2, and 3 grouts was demonstrated for both fresh and cured properties [5].

Results of this scale-up testing combined with previous closure experience at SRS will be used by CH2M HILL to generate design data to support closure of the Hanford HLW tanks.

\subsection{Objective}

The overall objectives of the scale-up testing include:

- Demonstrating solidification and encapsulation of the tank heel and debris in the Stabilization Layer by placement of the Phase 1 Stabilization Grout and Dry Stabilization Grout top dressing.

- Demonstrating equipment/riser filling and reduction of pathways for infiltration water.

- Demonstrating structural support and intruder mitigation for the Phase 2 and 3 Layers, respectively.

- Demonstrating commercial-scale production of the tank closure grouts (remote-location ready mix plant), transportation via truck, and placement via gravity or pumping into a slick line (w/wo tremie) and via pump truck with a boom and elephant trunk.

- Demonstrating formulation adjustment (water and admixture) upon delivery to achieve flow requirements.

- Correlating flow data obtained per ASTM D-6103 during the adjustment of the water and admixture in the field with the flow observed in the trench and pool forms to establish flow test specifications for the tank closure grouts.

- Evaluating compositional variability resulting from central batching

- Correlating properties measured for laboratory mixes ( 0.5 cubic feet) versus full-scale mixes prepared for the field (7 cubic yards). 
WSRC-TR-2003-00556, Rev. 0

December 15, 2003

Page 5 of 55

Each grout layer in the Hanford tank closure concept also had test specific test objectives as indicated below.

- $\quad$ Phase 1 Layer (Stabilization Grout)

- $\quad$ Flow, 40 and 75 feet

- Interaction with simulated heel (solid heel and heel supernate)

- Interaction with debris (simulated equipment, and gravel)

- Effect of dished bottom

- $\quad$ Placement of top dressing

- Interaction of top dressing and heel supernate

- Interaction of top dressing and underlying stabilizing grout

- Interaction top dressing and overlying stabilizing grout and/or structural grout.

- Cold joint formation

- $\quad$ Phase 2 Layer (Structural Grout)

- Flow 40 and 75 feet

- Cold joint formation and relevance

- $\quad$ Phase 3 Layer (Capping Grout)

- Flow 40 and 75 feet

- Cold joint formation and relevance

- Dome filling against 8 feet of grout head pressure

- Riser/Equipment Stabilization Grout (Commercial Cable Grout)

- Most limiting case filling scenario

\subsection{Approach}

The approach for conducting the scale-up testing is documented in the TTP/QAP, which was reviewed and approved by CH2M HILL [4]. Grouts made with SRS ingredients that have fresh and cured properties similar to the 3 Hanford grouts were substituted for grouts made with actual Hanford materials. Batches up to 7 cubic yards were prepared at a local ready mix plant and delivered to the test site in a standard concrete truck to simulate actual field production. Final mix adjustments (water and admixture additions to achieve flow properties) were made at the delivery site.

The placement methods included direct gravity discharge into the forms, pumping through a five-inch slick line with discharge directly or via a tremie into the form or pumping through a boom on a boom truck into a form. Four different form configurations were used to evaluate the placement issues:

- Three trenches 2 × 3.5 x 80 long were used to evaluate flow.

- Two swimming pools 4 feet high and 15 feet in diameter were used to evaluate interactions with simulated heels.

- Two metal culverts 2 feet in diameter and 10 feet long were used to evaluate pumping against 8 feet of head pressure.

- Five 1-inch diameter PVC pipes 20 to 60 feet long were used to evaluate the worst case for riser and equipment filling. 


\subsection{EXPERIMENTAL METHODS}

\subsection{Test Location}

The Burma Road Landfill was selected for the scale-up testing because it is cleared, flat land that is accessible to construction equipment and concrete delivery trucks. It also afforded easy access from Central Shops, where most of the craft and equipment used in the testing was located. The site also provided easy disposal of the test material.

The Landfill is approximately 145 acres and is located on the north side of Burma Road about 2 miles from C Road in the center of the Site. It was originally a sand borrow pit that was subsequently filled with clean soil from around the Site. The landfill is also used for disposal of other clean fill material including residues from washing out concrete trucks that deliver to SRS.

The Hanford closure grout scale-up test was located at the northwest side of the SRS Burma Road landfill as shown in Figure 3-1. The actual testing took place over a five-week period from 10-27-03 to 11-26-03. All of the forms were dismantled and material generated during the testing was disposed by 11-26-03. Planning with the Construction personnel began in mid August 2003. A list of equipment used to construct the forms and to carry out the test program is provided in Table 3-1.

Task activities including trench excavations and disposal of test materials, were within the scope of the landfill operations so the approval process did not impact the schedule. The crafts involved in the scale-up test included: Laborers, Concrete Masons, Carpenters, Heavy Equipment Operators, Teamsters, Painters, and Ironworkers.

An Automated Hazards Analysis, AHA, was generated October 22 and required the approval signatures of Industrial Hygiene, Environmental Compliance Authority, Radiological Control Operations, Generator Certification Official, and Safety. The AHA provided oversight on the initial trial run and subsequent grout testing. A subtask was created on the main AHA for handling the simulated sludge SRTC used in the pools. The pre-job briefing was given on October 23 to all craft involved. Testing began October 27, 2003. 
WSRC-TR-2003-00556, Rev. 0

December 15, 2003

Page 7 of 55

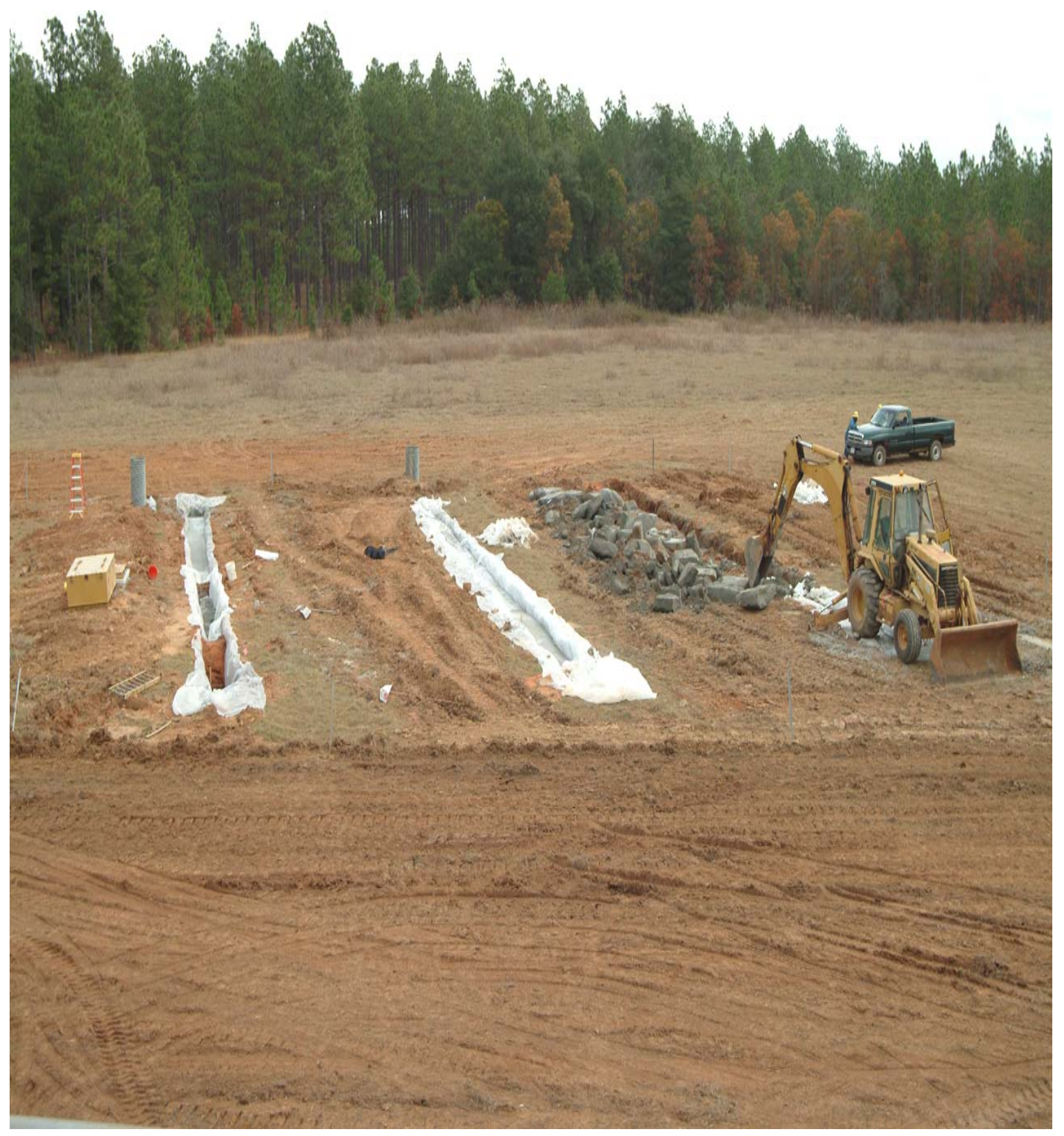

Figure 3-1. Burma Road Landfill test location for the Hanford grout scale-up tests. The three 80-foot long trench forms are shown. The first trench to be completed is being dismantled. 
WSRC-TR-2003-00556, Rev. 0

December 15, 2003

Page 8 of 55

Table 3-1. Equipment List.

\begin{tabular}{|c|c|c|}
\hline & Equipment & Description \\
\hline 1 & Portable Breathing Air & With Ingersoll Rand 300 generator \\
\hline 2 & Pump Truck (2) & Schwing 801/28 \\
\hline 3 & JLG & Simon AT60C Constructo \\
\hline 4 & Small Grout Pump & Chemgrout standard with $3 / 4$ " discharge \\
\hline 5 & Forklift & $\begin{array}{l}\text { Caterpillar Front-end loader with forklift attachment. Needed } \\
\text { for all terrain use }\end{array}$ \\
\hline 6 & Backhoe & 446 Blanchard \\
\hline 7 & Slick line & 250' of 5" slick line with supports \\
\hline 8 & Elbows & Miscellaneous 5” elbows for slick line \\
\hline 9 & Sandblasting machine & Clemco Industries Co. Model \#2452 6cf capacity \\
\hline 10 & Funnel & \\
\hline 11 & Screen & 4' $\mathrm{x}$ 4' sheet of $1-1 / 2$ " $\mathrm{x} 3 / 4^{\prime \prime}$ expanding metal \\
\hline 12 & Eyewash Station & Bradley \\
\hline 13 & Drinking Water/Wash water & \\
\hline 14 & Scaffolding & 30’ Tubeloc system \\
\hline 15 & B-12 (3) & Container Products Corporation \\
\hline 16 & Ladders & Straight and Step \\
\hline 17 & Stakes & 30 Wooden \\
\hline 18 & Water truck & $\begin{array}{l}\text { For cleaning slick line, grout pump equipment, concrete } \\
\text { equipment, etc. }\end{array}$ \\
\hline 19 & Soil Staples & To attach plastic to the ground \\
\hline 20 & Pump & To drain water from trenches \\
\hline 21 & Rabbit & To clean slick line \\
\hline 22 & Dozer & Caterpillar D7G \\
\hline 23 & Plastic & 16 rolls $10^{\prime} \times 100{ }^{\prime} 6 \mathrm{MIL}$ \\
\hline 24 & Air Compressor & Ingersoll Rand 450 \\
\hline 25 & Hut & Plastic 20’ x 20’ x 14’ \\
\hline 26 & Survey Equipment & Hand level and grade stick \\
\hline 27 & Generators & Ingersoll Rand L8 \\
\hline 28 & Equipment Trucks & For miscellaneous material pickup \\
\hline 29 & Tremie & \\
\hline 30 & Concrete Mixer & Drill with mixer drill bit \\
\hline 31 & Reducer & To take grout discharge of 3/4” to 3/8” \\
\hline 32 & Sieve & \#14 used to sieve grout into funnel on grout pump \\
\hline 33 & Concrete Vibrators & 2 \\
\hline 34 & Chemical Pallets & 2 \\
\hline 35 & Pipe & 8-1” PVC pipe 20’ lengths \\
\hline 36 & Fittings & 6 caps, $3-45^{\circ}$ angles, $1-90^{\circ}$ angle, $2-1^{\prime}$ extensions \\
\hline 37 & Tubing & $1300^{\prime}$ of $3 / 8^{\prime \prime}, 25{ }^{\prime}$ of $1 / 4 ”$ \\
\hline 38 & Shovels & For fine digging of trenches \\
\hline 39 & Hammers & For driving stakes and soil staples \\
\hline 40 & Plastic & To cover pool from elements \\
\hline 41 & Galvanized Pipe & 2 at $2^{\prime} \mathrm{D} \times 8^{\prime} \mathrm{L}$ \\
\hline 42 & Barricade stands & \\
\hline 43 & Barricade rope & With warning tags \\
\hline
\end{tabular}




\subsection{Test Forms}

Four types of forms were constructed for the Hanford grout placement tests. The forms were selected to address placement issues raised by CH2M HILL. The forms are summarized in Table 3.2.

Table 3-2. Summary of Forms Used in Scale-up Testing.

\begin{tabular}{|l|c|c|l|}
\hline Form Type & $\begin{array}{c}\text { Form } \\
\text { Dimensions }\end{array}$ & $\begin{array}{c}\text { Number } \\
\text { of forms }\end{array}$ & \multicolumn{1}{|c|}{ Test Objective } \\
\hline Plastic-lined trench & $2 \times 3 \times 80 \mathrm{ft}$ & 3 & $\begin{array}{l}\text { Evaluate flow, self-leveling, bleed water, } \\
\text { pour rate, segregation with vibration and } \\
\text { as a function of drop height up to 10 feet. }\end{array}$ \\
\hline $\begin{array}{l}\text { Plastic-lined } \\
\text { swimming pools }\end{array}$ & $\begin{array}{c}4 \mathrm{ft} \text { deep, } \\
15 \mathrm{ft} \text { diameter }\end{array}$ & 2 & $\begin{array}{l}\text { Evaluate interaction with simulated heel, } \\
\text { equipment and debris, top dressing } \\
\text { solidification, dusting, cold joints between } \\
\text { grout layers and grout and top dressing }\end{array}$ \\
\hline Metal culverts & $\begin{array}{c}10 \mathrm{ft} \text { long, } \\
2 \mathrm{ft} \text { diameter }\end{array}$ & 2 & $\begin{array}{l}\text { Evaluate pumping against a head of eight } \\
\text { feet of grout to simulate dome filling from } \\
\text { an off center riser. }\end{array}$ \\
\hline $\begin{array}{l}\text { PVC pipes - blanked } \\
\text { off bottom }\end{array}$ & $\begin{array}{c}20-60 \mathrm{ft} \text { long, } \\
1 \mathrm{in} \text { diameter }\end{array}$ & 5 & $\begin{array}{l}\text { Limiting case for riser and equipment } \\
\text { filling. }\end{array}$ \\
\hline
\end{tabular}

Three trenches two feet wide, three feet deep and 80 feet long were excavated and lined with plastic sheeting to evaluate flow distances of 40 and 75 feet. See Figures 3-2 and 3-3. The length of these forms is approximately the maximum distance of a grout flow in the large Hanford HLW tanks. Tank C-106 is about 80 feet in diameter and has riser accesses near the edges of the tank top. In addition, a shallow trench was excavated for a practice pour that was completed prior to the actual testing.

Above ground swimming pools were used as forms for testing that involved stabilization of simulated heel material. The swimming pools were four feet deep, had a diameter of 15 feet, and consisted of aluminum frames and 6 mil plastic liners. The pools were assembled on a layer of clay-sand that was slightly dished with a six-inch deep profile in the center to simulate the dished bottoms of Tank C-106 and the C-200 Tanks. See Figure 3-4. A plastic hut was constructed around one of the pools to control dust from the dry grout top dressing experiments. See Figure 3-5. Top dressing was not used in the pool without a hut.

Simulated heels were prepared and placed on the bottom of both pools. Swimming Pool 1 (SP1) contained approximately 150 gallons of a sodium nitrate, sodium oxalate solution that was formulated to represent the composition of the heel in Tank C-106 after waste retrieval $[6,7,8]$. Swimming Pool 2 (SP2) contained approximately 50 gallons of sludge designed to approximate a worst case condition for the average heel in the C-200 Series tanks. 
WSRC-TR-2003-00556, Rev. 0

December 15, 2003

Page 10 of 55

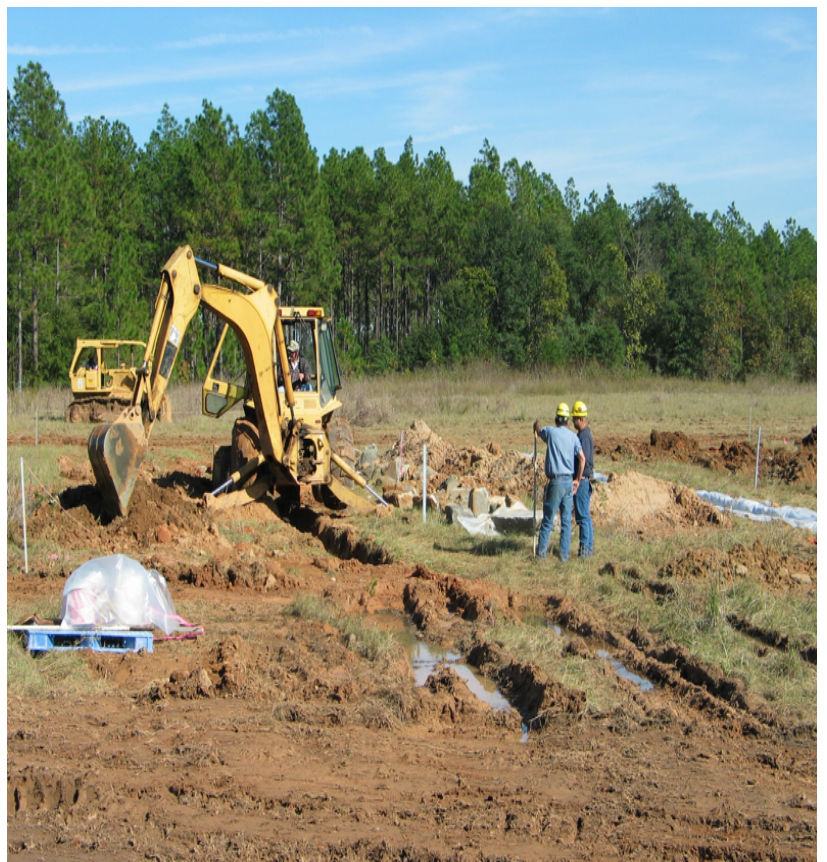

Figure 3-2. Trench form construction.

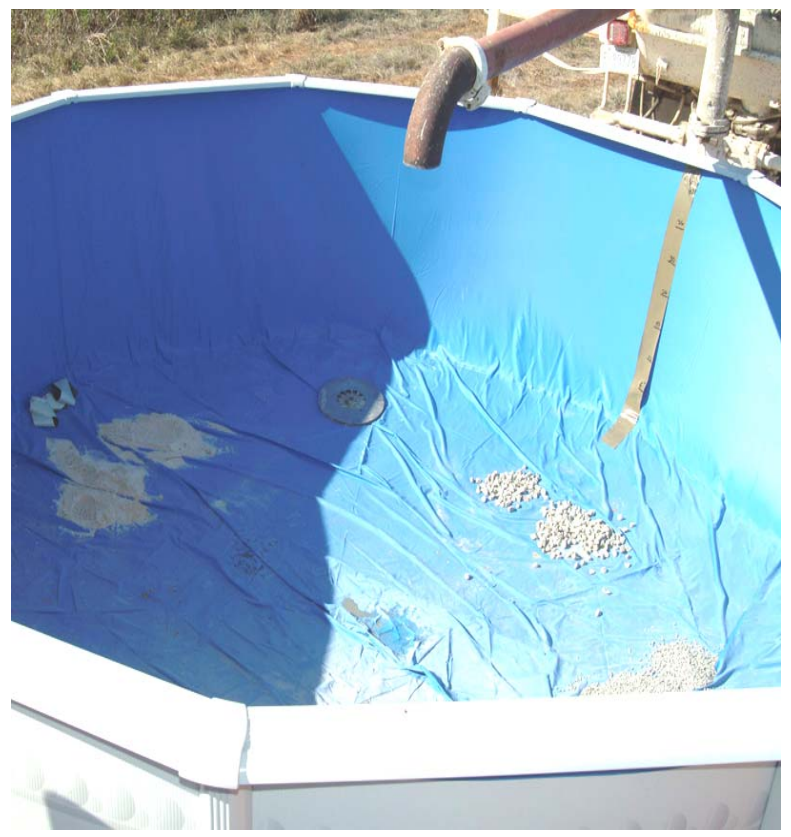

Figure 3-4. Swimming Pool 2 without hut.

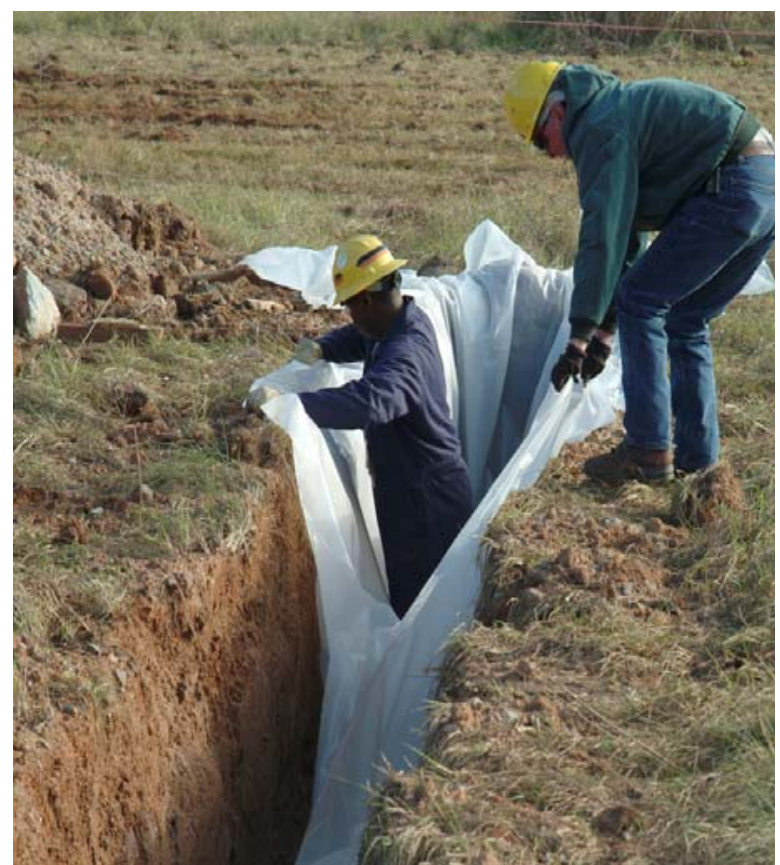

Figure 3-3. Plastic liner installation in trench.

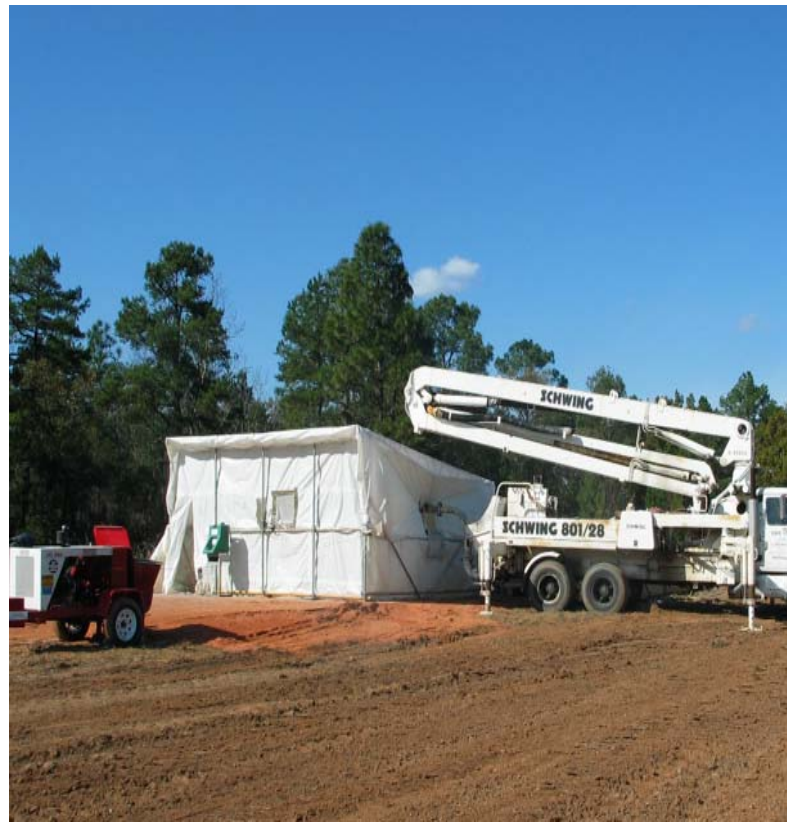

Figure 3-5. Plastic hut around Swimming Pool 1 and and pump truck .

Two additional test forms were used. Two culverts, two feet in diameter and 10 feet long were partially buried in the ground. These forms were used to evaluate pumping against about 8 feet of grout head pressure. Grout was discharged into these culverts through a slick line that 
WSRC-TR-2003-00556, Rev. 0

December 15, 2003

Page 11 of 55

discharged between 6 and 12 inches from the bottom of each culvert. The culverts were filled to within a foot of the top. See Figures 3-6 and 3-7.

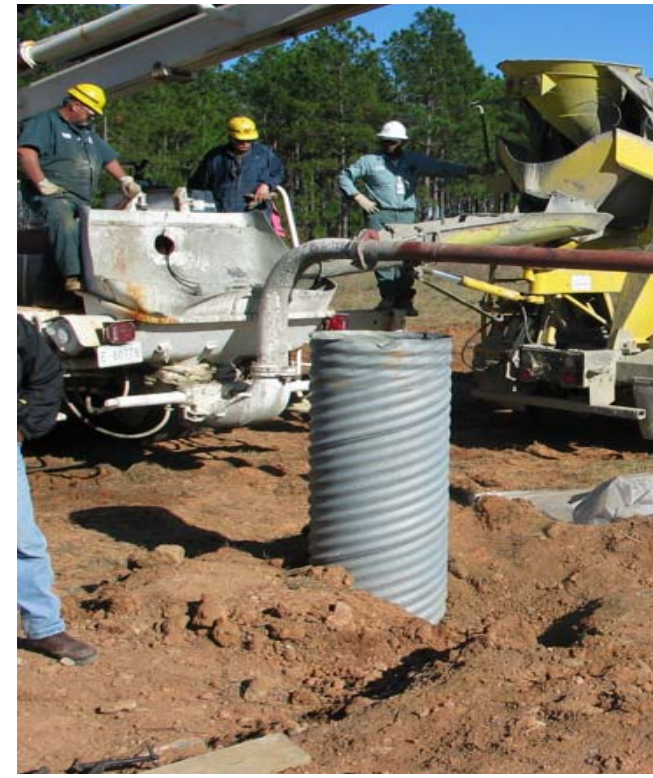

Figure 3-6. Metal culvert form.

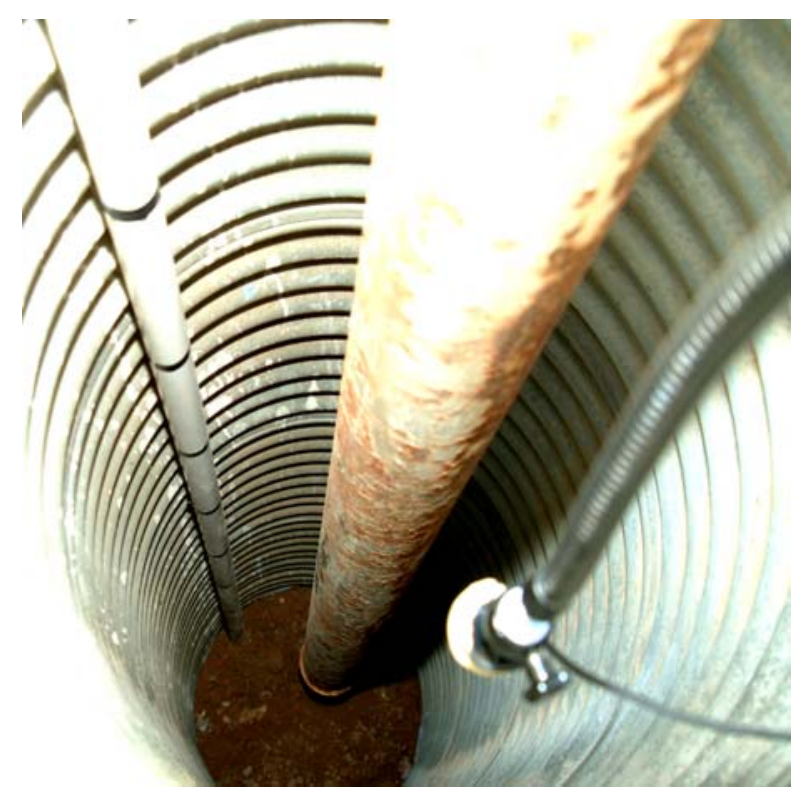

Figure 3-7. Metal culvert form (inside).

PVC pipes one-inch in diameter were used to simulate restricted riser space filling and equipment filling. The PVC pipes were blanked off at the bottom end. Filling was accomplished by one of two methods: 1) gravity filling from the top, and 2) filling from the bottom up by pumping grout though a 3/8 inch flexible tube inserted to within a few inches from the bottom of the PVC pipe. Instrument wires were added to one of the PVC pipe forms to simulate additional obstructions. See Figures 3-8 and 3-9.

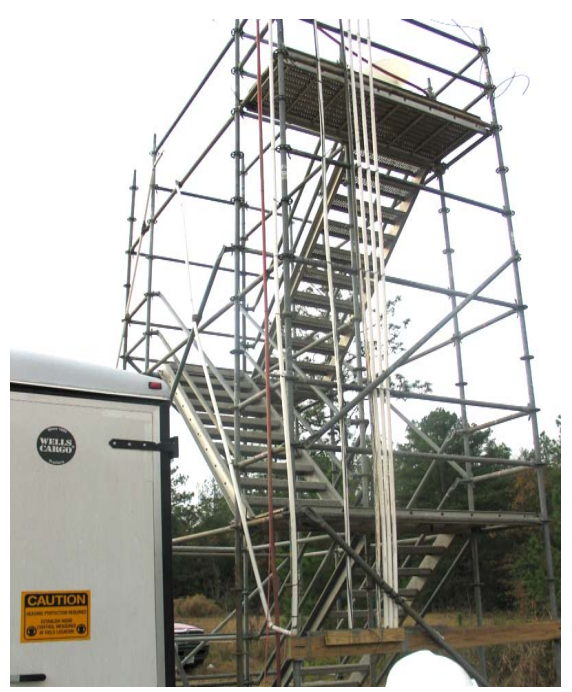

Figure 3-8. PVC pipe forms.

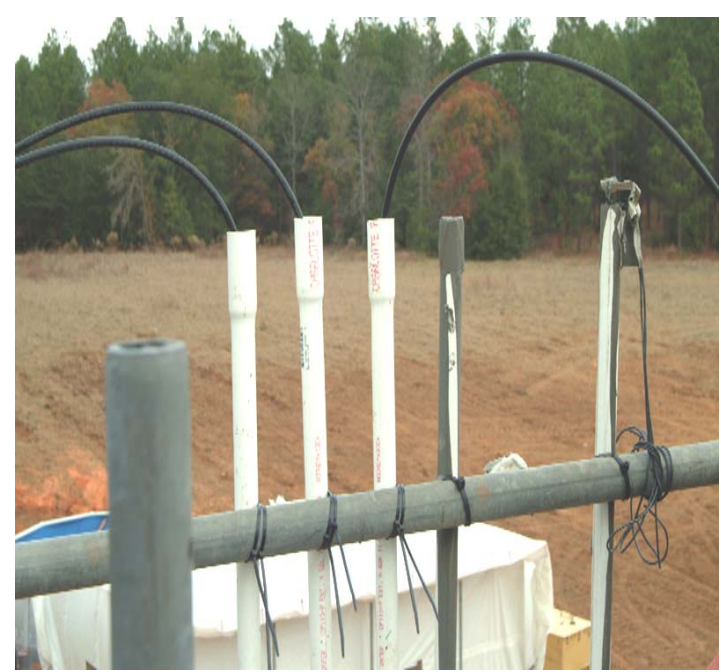

Figure 3-9. Top of one-inch PVC forms. 


\subsection{Simulated Heel Preparation}

\subsubsection{Chemical Simulants}

Simulants were prepared to represent both the chemical and physical characteristics of the heels that are expected in Tank C-106 and the C-200 series tanks at the time of filling. Compositions of the chemical simulants were the same as those used in the earlier binder study $[6,7,8]$.

The C-106 chemical simulant used in this test accounts for the oxalic acid heel retrieval and subsequent neutralization with sodium hydroxide. The composition of the C-200 series simulant was approximated by assuming that some of the heel was left in the tanks and that wash water introduced into the tank(s) dissolved soluble salts to form a saturated supernate.

Two hundred gallons of the C-106 chemical simulant were prepared for the scale-up testing. One hundred and fifty gallons were used in the swimming pool test. The remaining fifty gallons was used in Trench 3 to determine the amount of top dressing required to solidify 50 gallons of liquid. One hundred gallons of the C-200 series chemical simulant were also prepared. Fifty gallons were placed in the Swimming Pool 2 and 50 gallons were used in the Trench 3 test.

Ingredients for the C-106 and C-200 series simulants are listed in Tables 3-3 and 3-4, respectively. The laboratory setup used to prepare the simulants is shown in Figure 3-10. Each batch was prepared in a poly mixing tank charged with water. The chemicals were added into the vortex created by an overhead stirrer. Five minutes was allowed between additions and the temperature was monitored to prevent exceeding $50^{\circ} \mathrm{C}$ (SRNL safety concern). The mixtures were then pumped into 55-gallon poly drums that were weighed, labeled and shipped to the test site.

Table 3-3. Simulated C-106 Heel Ingredients.

\begin{tabular}{|l|c|c|c|c|}
\hline Ingredient & Supplier & CAS No. & Moles/Liter (M) & Kg/drum (50 gallon batch) \\
\hline $\mathrm{Na} 2 \mathrm{C} 2 \mathrm{O} 4$ & FMC & $12763-1$ & 0.02 & 0.5 \\
\hline $\mathrm{NaOH}$ & Fisher & $6911-1$ & 0.43 & 3.2 \\
\hline
\end{tabular}

Table 3-4. Simulated C-200 Heel Ingredients.

\begin{tabular}{|l|c|c|c|c|}
\hline Ingredient & Supplier & CAS No. & Moles/Liter (M) & Kg/drum (50 gallon batch) \\
\hline KCL & Mallinckrodt & $8691-1$ & 0.0045 & 0.0634 \\
\hline NaNO3 & Fisher & $8933-1$ & 0.172 & 2.767 \\
\hline NaNO2 & Fisher & $6808-1$ & 0.068 & 0.888 \\
\hline Na2SO4 & Fisher & $5010-1$ & 0.017 & 0.456 \\
\hline Na2CO3 & FMC & $12763-1$ & 0.122 & 2.447 \\
\hline NaC2O4 & Fisher & $6806-1$ & 0.025 & 0.591 \\
\hline NaF & Fisher & $6925-1$ & 0.023 & 0.184 \\
\hline $\mathrm{Al}(\mathrm{OH}) 3$ & Fisher & $11929-1$ & 1.54 & 22.7 \\
\hline
\end{tabular}




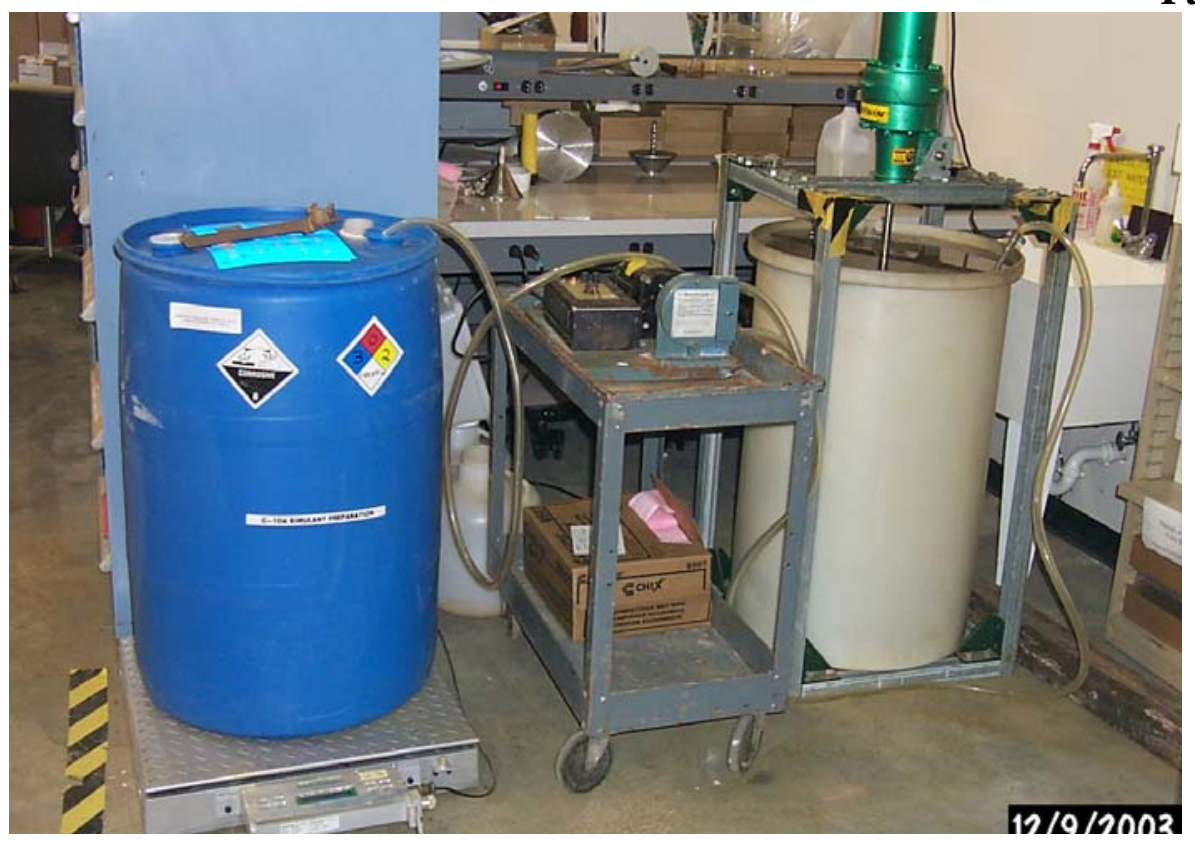

Page 13 of 55

Figure 3-10. Photograph of set up used to prepare simulated tank heels.

\subsubsection{Physical Simulants}

The physical properties of the C-106 and 200 series heels were simulated with several types of inert materials, such as, 1.5 inch gravel, $3 / 8$ inch pea gravel, sand, and clay-sand soil, placed in piles about 20 inches in diameter on the pools bottoms. In the case of the C-200 series tanks, sludge particulates were simulated with aluminum hydroxide. Simulated debris was also placed in the pool forms and included: metal spools, impellers (13.5 inches in diameter), flanges, rings (17 inches in diameter), shavings, and stanchions (15 inches tall with 6 inch square bases). The simulated debris and physical simulants are illustrated in Figures 3-11and 3-12.

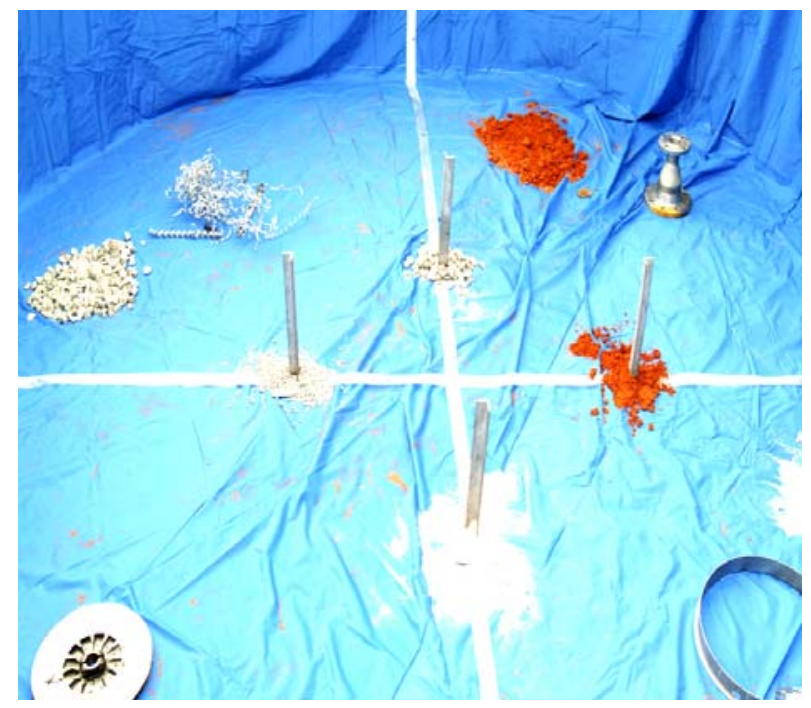

Figure 3-11. Physical simulants in Pool 1.

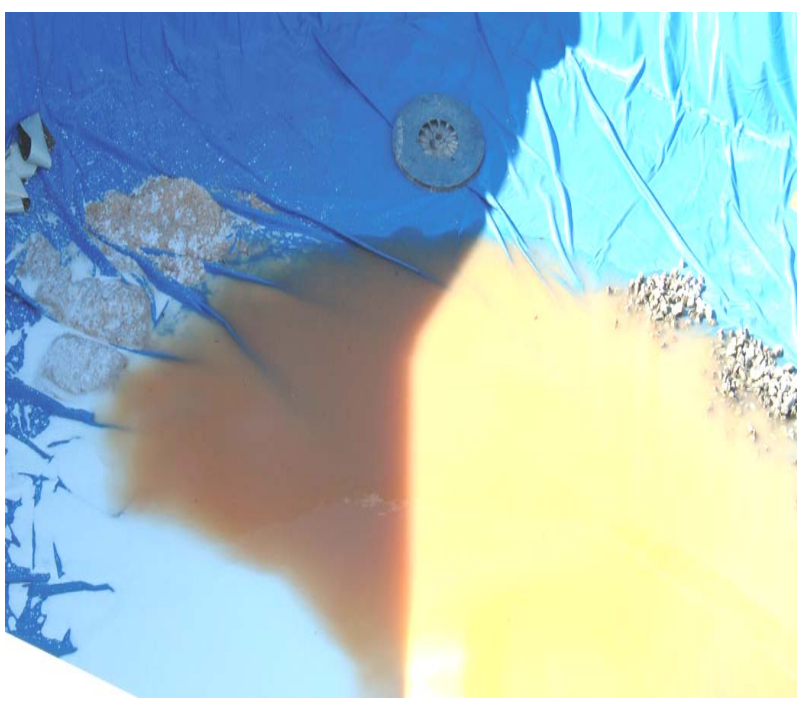

Figure 3-12. Physical and chemical simulants in Pool 2. (Simulated supernate was yellow.) 


\subsection{Tank Fill Grout}

\subsubsection{Mix Designs}

Three mix designs were selected for closing the Hanford waste tanks based on earlier benchscale formulation studies [5, 9]. Materials obtained from the Hanford area were used to develop these grouts. Mixes HRG4, HRG2, and HRG9 (Hanford reducing grouts 4, 2, and 9) were selected to meet the CH2M HILL requirements for the Phase 1 Grout (Stabilizing Layer), Phase 2 Grout (Structural Layer) and Phase 3 Grout (Capping Grout), respectively.

Since the Burma Road Site at SRS was selected for the scale-up testing, three SRS mixes, using materials locally available in South Carolina, SRG2, SRG4, and SRG9, were designed specifically for this testing. Equivalency of these mixes to the corresponding Hanford mixes was demonstrated in bench-scale studies and documented elsewhere [5, 9]. The ingredients and proportions in the Hanford tank closure grout mixes are listed in Table 3-5.

The ingredients and proportions in the equivalent mixes containing materials available at the SRS are listed in Table 3-6. The mixes were designed to have a flow of 13.5 to 15 inches. The amount of binder, binder proportions, and admixtures were held constant for equivalent mixes and adjustments were made in sand and water.

Table 3-5. Hanford tank closure grout formulations for a 15 inch flow per ASTM D-6103.

\begin{tabular}{|l|c|c|c|c|}
\hline Ingredients & Supplier & $\begin{array}{c}\text { HRG4 } \\
\text { (Stabilizing) }\end{array}$ & $\begin{array}{c}\text { HRG2 } \\
\text { (Structural) }\end{array}$ & $\begin{array}{c}\text { HRG9 } \\
\text { (Capping) }\end{array}$ \\
\hline Portland cement $\left(\mathrm{lbs} / \mathrm{yd}^{3}\right)$ & Ash Grove, WA & 225 & 75 & 280 \\
\hline Slag $\left(\mathrm{lbs} / \mathrm{yd}^{3}\right)$ & Holcim, AL & 210 & 210 & 210 \\
\hline Fly ash $\left(\mathrm{lbs} / \mathrm{yd}^{3}\right)$ & Central Pre Mix, WA & 225 & 375 & 170 \\
\hline Sand $\left(\mathrm{lbs} / \mathrm{yd}^{3}\right)$ & Central Pre Mix, WA & 2530 & 2530 & 2530 \\
\hline $\begin{array}{l}\text { Water }(\mathrm{gal} / \mathrm{cyd}) \\
\left(\mathrm{lbs} / \mathrm{yd} d^{3}\right)\end{array}$ & $\begin{array}{c}\text { SRS } \\
\text { KelcoCrete }\left(\mathrm{g} / \mathrm{yd}^{3}\right)\end{array}$ & $\begin{array}{c}58 \\
(483)\end{array}$ & $\begin{array}{c}54 \\
(450)\end{array}$ & $\begin{array}{c}62 \\
(516)\end{array}$ \\
\hline Advaflow $\left(\mathrm{fl.oz} / \mathrm{yd}^{3}\right)$ & CP Kelco, CA & 275 & 275 & 275 \\
\hline
\end{tabular}

Table 3-6. SRS equilavent grout formulations used for scale-up testing.

\begin{tabular}{|c|c|c|c|c|}
\hline Ingredients & Supplier & $\begin{array}{c}\text { SRG4 } \\
\text { (Stabilizing) }\end{array}$ & $\begin{array}{c}\text { SRG2 } \\
\text { (Structural) }\end{array}$ & $\begin{array}{c}\text { SRG9 } \\
\text { (Capping) }\end{array}$ \\
\hline Portland cement (lbs/yd ${ }^{3}$ ) & Giant Cement, SC & 225 & 75 & 280 \\
\hline Slag $\left(\mathrm{lbs} / \mathrm{yd}^{3}\right)$ & Holcim, AL & 210 & 210 & 210 \\
\hline Fly ash (lbs/yd $\left.{ }^{3}\right)$ & $\begin{array}{c}\text { Southeastern Fly } \\
\text { Ash, NC }\end{array}$ & 225 & 375 & 170 \\
\hline Sand (lbs/yd ${ }^{3}$ ) & LaFarge, GA & 2150 & 2150 & 2150 \\
\hline $\begin{array}{l}\text { Water (gal/cyd) } \\
\left(\mathrm{lbs} / \mathrm{yd}^{3}\right)\end{array}$ & $\begin{array}{c}\text { SRS } \\
\text { Domestic Supply }\end{array}$ & $\begin{array}{c}66 \\
(551)\end{array}$ & $\begin{array}{c}58 \\
(483)\end{array}$ & $\begin{array}{c}66 \\
(551)\end{array}$ \\
\hline KelcoCrete $\left(\mathrm{g} / \mathrm{yd}^{3}\right)$ & CP Kelco, CA & 275 & 275 & 275 \\
\hline Advaflow (fl.oz/yd ${ }^{3}$ ) & W. R. Grace & 90 & 90 & 90 \\
\hline
\end{tabular}




\subsubsection{Batching and Transportation}

Page 15 of 55

Grout was batched at the LaFarge Ready Mix Plant in Jackson, SC. See Figure 3-13. The plant is located approximately 10 miles from the Burma Road test site. The batch size for most of the testing was seven cubic yards. (A one-foot thick layer in the 80-foot long trench was calculated to be about 6.5 cubic yards.)

The mix was delivered in a relatively dry form. Ten gallons of water per cubic yard or a total of 70 gallons of water was held back at the batch plant. This was necessary because the mix in its final fluid form is not easily transported in a concrete delivery truck. Both the admixture blend (mixture of Advaflow and Kelcocrete) and all or part of the hold-back-water was added at the test site. The amount of water and admixture was determined by flow testing on each batch of material. See Figures 3-14 and 3-15. For the scale-up testing, the grout was adjusted to achieve a flow of 13.5 to 15 inches per ASTM D-6013. In addition, the appearance of the mixture before and after flow was evaluated and used to determine whether water, admixture, or both were required. After each addition of water and/or admixture, the batch was mixed for approximately 3 minutes. Final mix compositions are listed in Table 3-7.

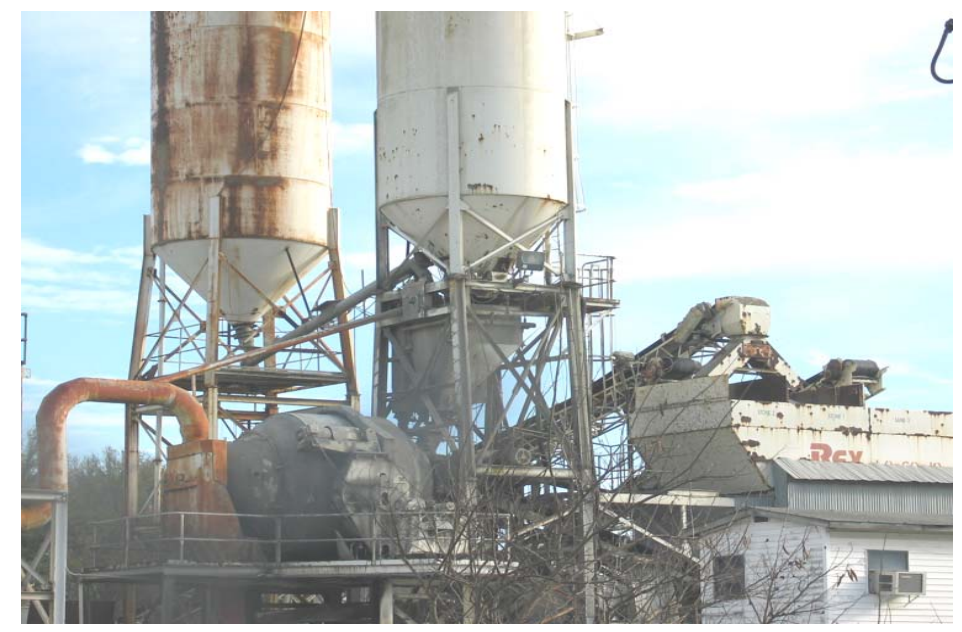

Figure 3-13. Photograph of central batch plant used to prepare grout mixes.

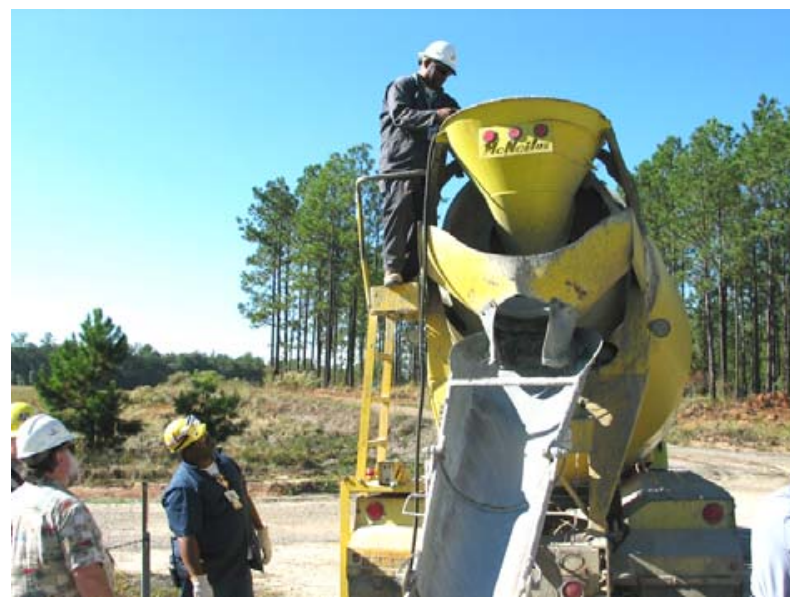

Figure 3-14. Grout delivery and adjustment.

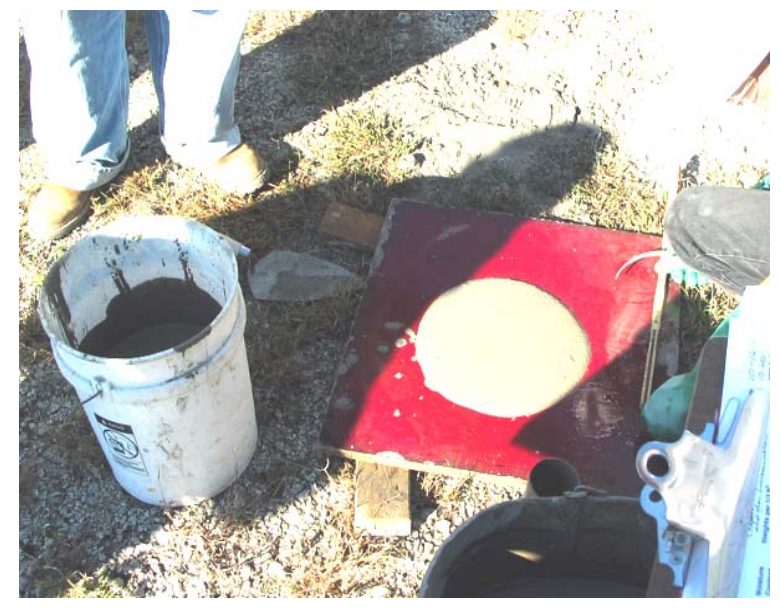

Figure 3-15. Photograph of flow test. 
WSRC-TR-2003-00556, Rev. 0

December 15, 2003

Page 16 of 55

Table 3-7. Ingredients and amounts per cubic yard for the mixes placed in the scale up tests.

\begin{tabular}{|c|c|c|c|c|c|c|c|c|c|c|c|c|c|c|c|c|}
\hline Placement & Mix & $\begin{array}{c}\text { Grout Phase } \\
\text { (Layer) }\end{array}$ & \multicolumn{2}{|c|}{ Portland Cement } & \multicolumn{2}{|c|}{$\begin{array}{c}\text { Blast Furnace } \\
\text { Slag }\end{array}$} & \multicolumn{2}{|c|}{ Fly Ash } & \multicolumn{2}{|c|}{ Sand } & \multicolumn{2}{|c|}{ Water* } & \multicolumn{2}{|c|}{ AdvaFlow* } & \multicolumn{2}{|c|}{ KelcoCrete* } \\
\hline & & & (lbs/cyd) & (lbs/cyd) & (lbs/cyd) & (lbs/cyd) & (lbs/cyd) & (lbs/cyd) & (lbs/cyd) & (lbs/cyd) & (gal/cyd & (gal/cyd) & (fl oz/cyd) & (fl oz/cyd) & (g/cyd) & (g/cyd) \\
\hline Layer 1 & SRG4 & STABILIZATION & 225 & 225 & 210 & 210 & 225 & 224 & 2263 & 2254 & 66 & 70 & 135 & 135 & 413 & 413 \\
\hline Layer 2 & SRG2 & STRUCTURAL & 75 & 75 & 210 & 209 & 375 & 375 & 2263 & 2257 & 58 & 60 & 135 & 135 & 413 & 413 \\
\hline Layer 3 & SRG9 & CAPPING & 280 & 281 & 210 & 211 & 170 & 171 & 2263 & 2257 & 66 & 70 & 135 & 135 & 413 & 413 \\
\hline Layer 2 & SRG2 & STRUCTURAL & 75 & 75 & 210 & 209 & 375 & 374 & 2242 & 2263 & 58 & 61 & 135 & 135 & 413 & 413 \\
\hline Layer 3 & SRG9 & CAPPING & 280 & 280 & 210 & 209 & 170 & 171 & 2242 & 2211 & 66 & 68 & 135 & 135 & 413 & 413 \\
\hline \multicolumn{17}{|c|}{ TRENCH 3} \\
\hline Layer 1 & SRG9 & CAPPING & 280 & 280 & 210 & 209 & 170 & 170 & 2238 & 2203 & 66 & 62 & 90 & 90 & 275 & 275 \\
\hline Layer 2 & SRG9 & CAPPING & 280 & 282 & 210 & 209 & 170 & 169 & 2238 & 2226 & 66 & 59 & 90 & 90 & 275 & 275 \\
\hline Layer 3 & SRG9 & CAPPING & 280 & 280 & 210 & 209 & 170 & 169 & 2226 & 2211 & 66 & 58 & 90 & 90 & 275 & 275 \\
\hline \multicolumn{17}{|c|}{ SWIMMING POOL 2} \\
\hline Layer 1 & SRG4 & STABILIZATION & 225 & 226 & 210 & 209 & 225 & 224 & 2261 & 2234 & 66 & 60 & 90 & 90 & 275 & 275 \\
\hline Layer 2 & SRG2 & STRUCTURAL & 75 & 75 & 210 & 209 & 375 & 372 & 2235 & 2243 & 58 & 55 & 105 & 105 & 321 & 321 \\
\hline Layer 3 & SRG9 & CAPPING & 280 & 280 & 210 & 209 & 170 & 169 & 2226 & 2211 & 66 & 58 & 90 & 90 & 275 & 275 \\
\hline \multicolumn{17}{|c|}{ CULVERT 1} \\
\hline Layer 1 & SRG9 & CAPPING & 280 & 280 & 210 & 209 & 170 & 170 & 2238 & 2203 & 66 & 62 & 90 & 90 & 275 & 275 \\
\hline \multicolumn{17}{|l|}{ CULVERT 2} \\
\hline \begin{tabular}{r|} 
Layer 1 \\
\end{tabular} & SRG9 & CAPPING & 280 & 280 & 210 & 208 & 170 & 168 & 2237 & 2233 & 66 & 56 & 135 & 135 & 413 & 413 \\
\hline
\end{tabular}

* The target water content shown in this table is based on a flow of 13.5 inches per ASTM D-6103 for samples prepared in the laboratory. In the field the target was used as a guide.

The flow and appearance were used to adjust the mixes using water addition and/or extra admixture addition. 


\subsubsection{Placement}

Placement through a 250-foot long five-inch diameter slick line was planned for all of the trench pours. However, problems with the pump and line required that several of the mixes be dumped out of the back of the truck at one end of the trench. See Figures 3-16 and 3-17. Pumping through the 250-foot long slick line was demonstrated for two of the placements. The rate of placement was estimated by recording the time required to empty the truck or pump.

A pump truck with a 150-foot boom was intended for placing grout in the swimming pools. Problems with the pump seals necessitated reconfiguring several section of the slick line into a suitable geometry that enabled successful placement in the pools. See Figures 3-18 and 3-19.

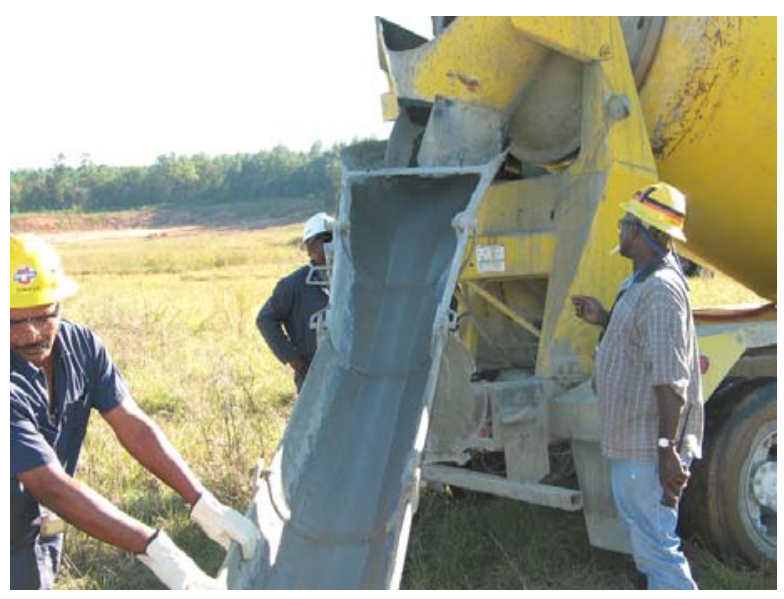

Figure 3-16. Gravity pour from a concrete truck chute into a trench form.

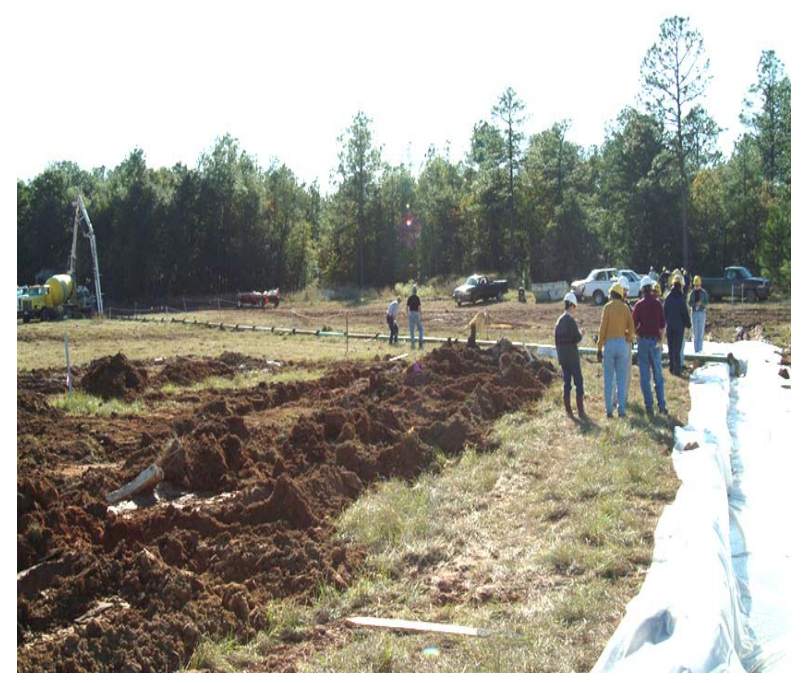

Figure 3-18. Slick line placement.

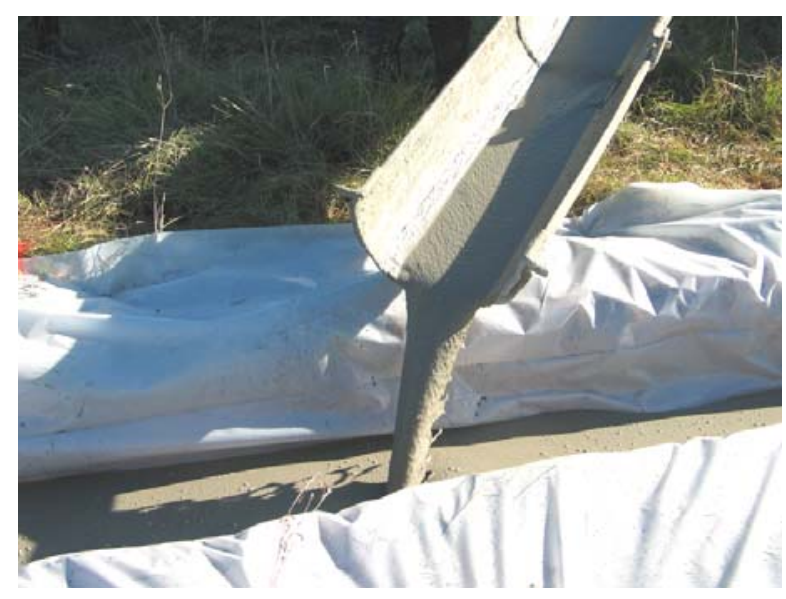

Figure 3-17. Gravity pour into a trench form from a concrete truck.

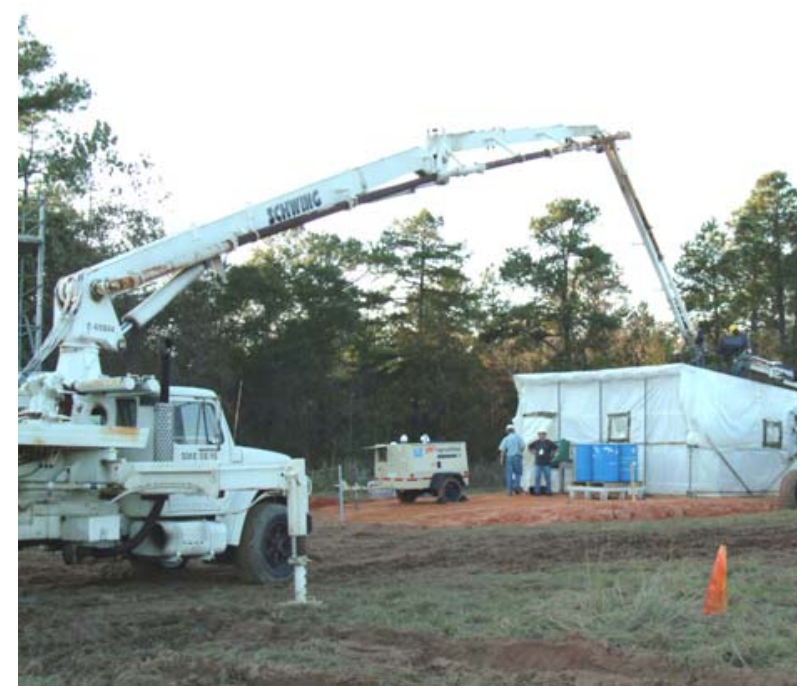

Figure 3-19. Attempted boom truck placement 
WSRC-TR-2003-00556, Rev. 0

December 15, 2003

Page 18 of 55

Consequently, alternative placement configurations had to be devised on the job site to get the grout into the various forms. Figures 3-20 and 3-21 illustrate the pumping from the hopper on the pump truck through three right-angle connections in to the swimming pools 1 and 2 respectively. Figure 3-22 illustrates a similar configuration with an 8-foot-long tremie attached to the slick line.

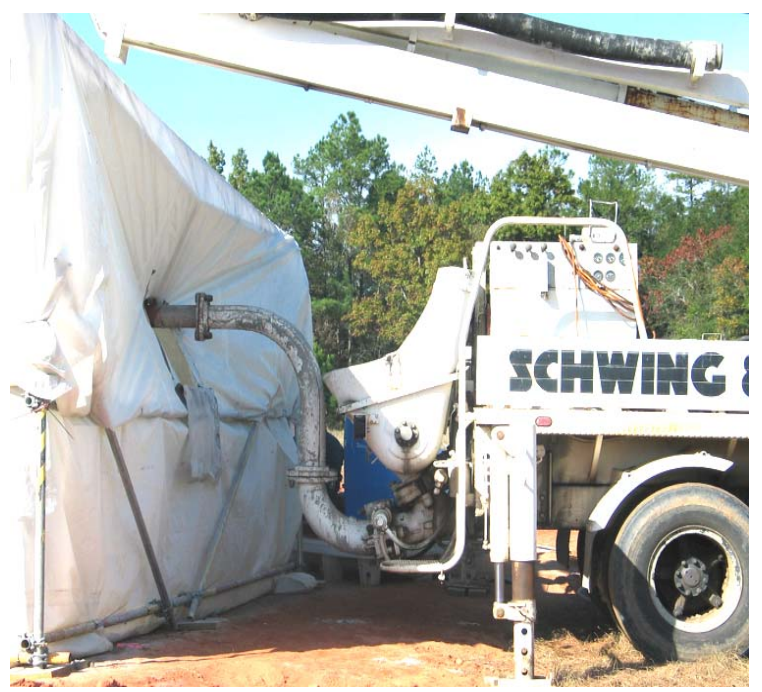

Figure 3-20. Placement into Pool 1 through a 5 inch steel pipe.

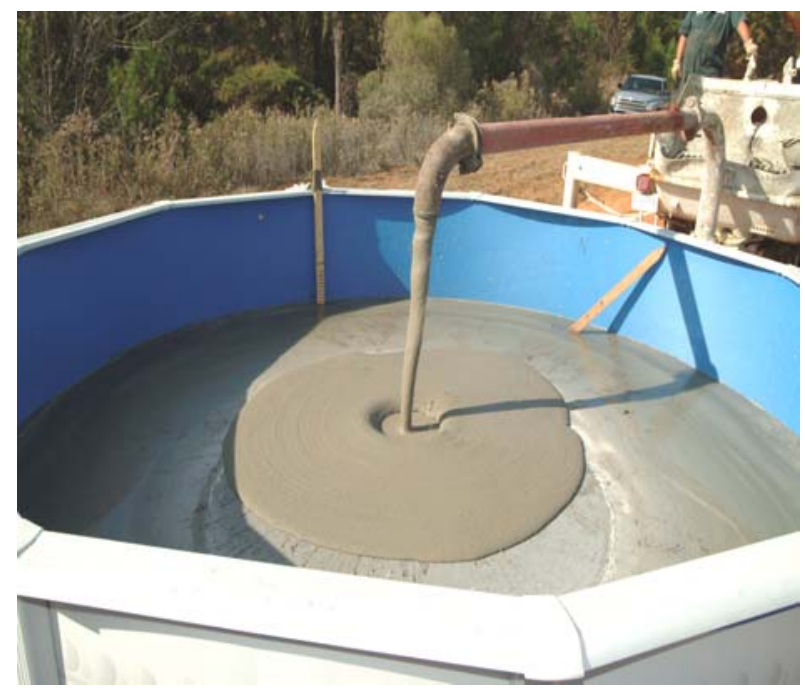

Figure 3-21. Placement into Pool 2 through a 5 inch steel pipe.

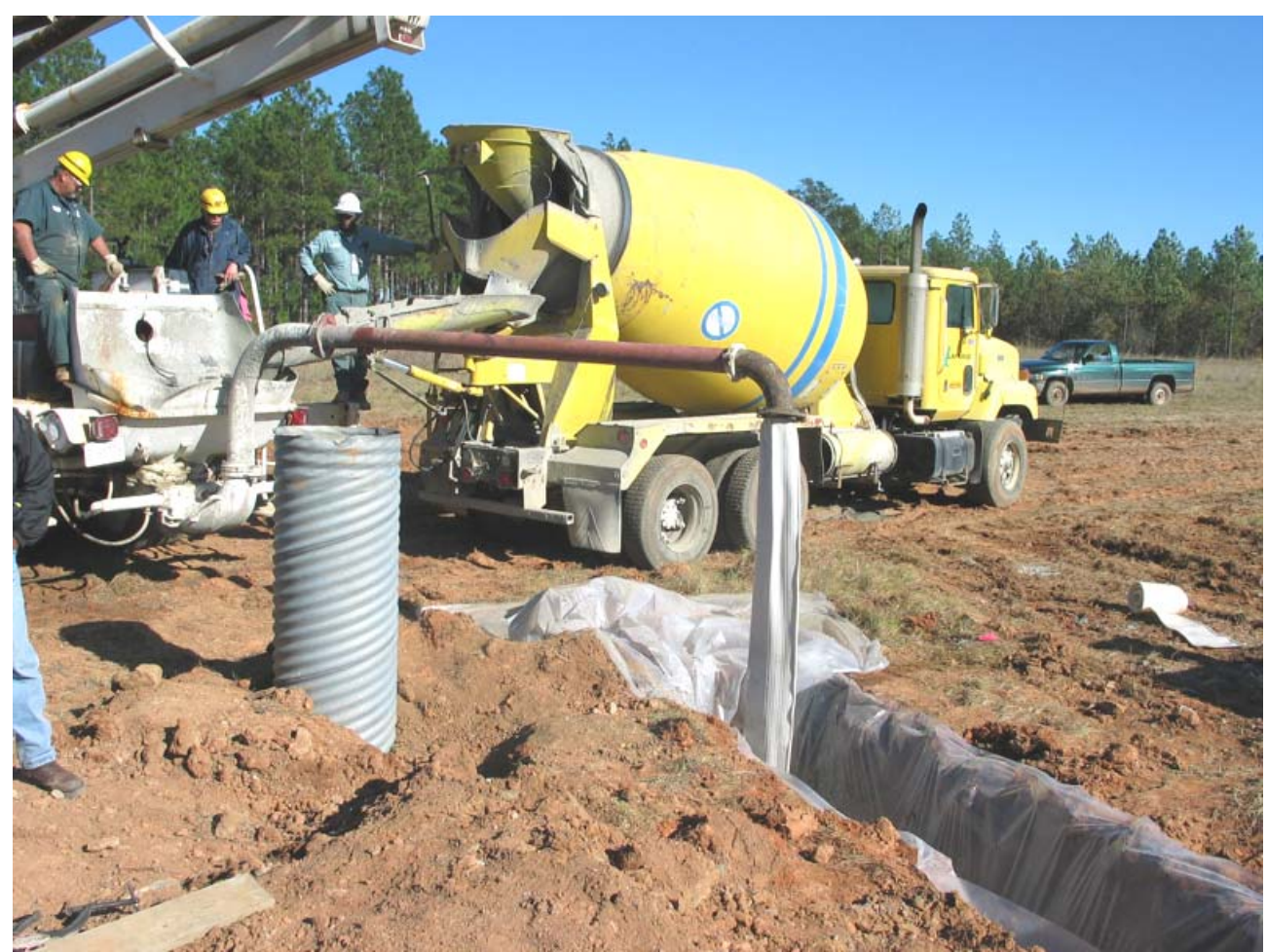

Figure 3-22. Placement through a 5 inch metal line with a flexible tremie at the discharge. 


\subsection{Top Dressing}

A mixture of Type I/II Portland cement, Grade 100 slag and Class F fly ash was used to top dress the supernate portion of the simulated heel in swimming pool 1. (The only source of pre-blended top dressing readily available for the scale-up testing was premix obtained from the SRS Saltstone facility. The premix had the same proportions as currently used in the Saltstone. Saltstone facility personnel and bagged the premix for use in the scale-up testing to demonstrate the concept.) A plastic hut was constructed over the pool to contain the dust. The dry powder mixture was pneumatically blown on top of the liquid heel from an opening on the roof of a plastic hut. A Clemco compressed air sand-blaster was used to place the dry powder. See Figures 3-23 and 3-24.

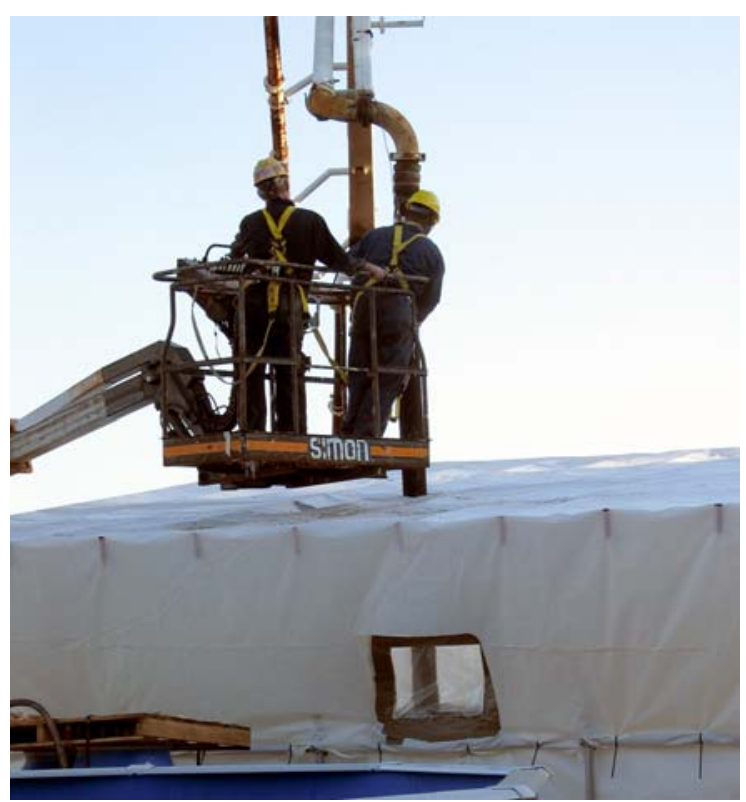

Figure 3-23. Top dress feed container.

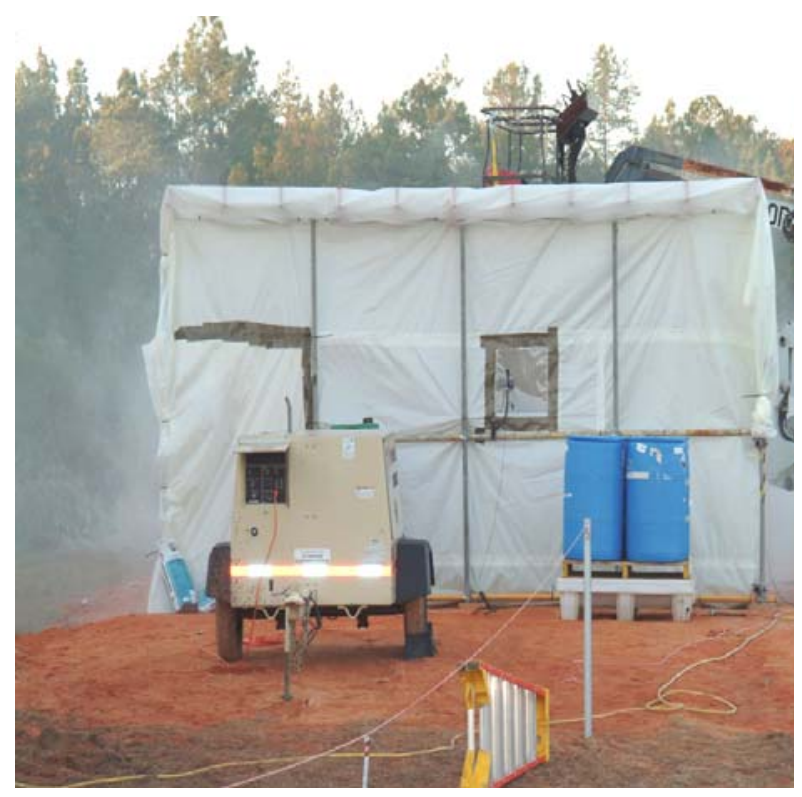

Figure 3-24. Top dress application from the top of the hut.

\subsection{Equipment and Riser Fill Grout}

\subsubsection{Grout Materials}

Three commercially available cable grouts were evaluated for filling risers, abandoned equipment and limited access void spaces. These grouts contain very fine aggregate, typically less than $0.1 \mathrm{~mm}$ in diameter and are routinely used at SRS to fill pipes and small voids. Applications recommended by the manufacturer and special features of these grouts are summarized in Table 3-8.

Masterflow ${ }^{\circledR} 816$ is a non-shrink, aggregate-free cable grout. It is used in applications requiring high early strength and no bleed water. The 816 slurry is pumpable and is used to flow into small spaces and between wire strands. This material has been used previously at SRS and is readily available. The working time is 30 to 45 minutes. (Set retarders are not recommended to extend the working time.) 
WSRC-TR-2003-00556, Rev. 0

December 15, 2003

Page 20 of 55

Masterflow ${ }^{\circledR} 1205$ grout is used to encapsulate highly stressed steel. It fills voids in restricted spaces between columns, plates, beams, etc. A specially graded aggregate allows the material to pump easily through long distances. An extended work time of 1 hour at $90^{\circ} \mathrm{F}$ is possible with this material. This material is normally used in long horizontal runs.

Masterflow ${ }^{\circledR} 1341$ is designed for filling vertical pipes. It is designed to be pumpable for long periods of time and hardens without settlement shrinkage. The mixture is thixotropic and a high shear mixer is recommended.

These grouts were available at the SRS and were selected as examples of commercially available products designed for placement applications similar to those encountered in HLW tanks and risers. These grouts are manufactured by Degussa, Inc., and ingredients are provided in the Material Safety Data Sheets available from the manufacturer.

Table 3-8. Cable grout information.

\begin{tabular}{|c|c|c|c|}
\hline Product & Supplier & Recommended Applications & Special Features \\
\hline Masterflow® 816 & Chemrex & $\begin{array}{l}\text { Cable/duct grout } \\
\text { Pre/post tensioned cables }\end{array}$ & $\begin{array}{l}\text { Aggregate free, } \\
\text { Fluid, } \\
\text { Non shrink, } \\
\text { Non bleed }\end{array}$ \\
\hline Masterflow® 1205 & Chemrex & $\begin{array}{l}\text { Long vertical runs } \\
\text { Post tensioned cables } \\
\text { Grout highly stressed steel }\end{array}$ & $\begin{array}{l}\text { Graded aggregate, } \\
\text { Pumpable, } \\
\text { Long working time, } \\
\text { Low shrinkage, } \\
\text { Non bleed }\end{array}$ \\
\hline Masterflow ${ }^{\circledR} 1341$ & Chemrex & $\begin{array}{l}\text { Post tensioned cables } \\
\text { Vertical pipes }\end{array}$ & $\begin{array}{l}\text { Pumpable, } \\
\text { Thixotropic, } \\
\text { Long work time, } \\
\text { Low shrinkage }\end{array}$ \\
\hline
\end{tabular}

\subsubsection{Grout Preparation and Placement}

The cable grouts were mixed in a 5-gallon plastic bucket with a paint mixer mounted on a portable drill. The water contents of these grouts were adjusted per the manufacturer's directions to achieve a flow of 18 to 22 seconds per the ASTM C-939 method. A No. 14 sieve was placed in the funnel that fed the grout pump to remove particles greater than $0.14 \mathrm{~mm}$ to minimize the chance of bridging/plugging in the 1-inch pipe and 3/8-inch discharge line. (The dimensions of the discharge line were selected to demonstrate filling of a one-inch pipe with a reasonable expectation of success.) A Chem Grout pump was used to pump grout into the oneinch PVC pipe forms that simulated restrictive riser configurations. One PVC pipe was filled by gravity and, the grout was poured directly into the pipe from a small hose attached to a funnel held above the opening of the PVC. The other pipes were filled from the bottom up. Grout was pumped through a length of hard 3/8-inch tubing inserted into the pipe to a few inches from the bottom. See Figures 3-25 to 3-28. 
WSRC-TR-2003-00556, Rev. 0

December 15, 2003

Page 21 of 55

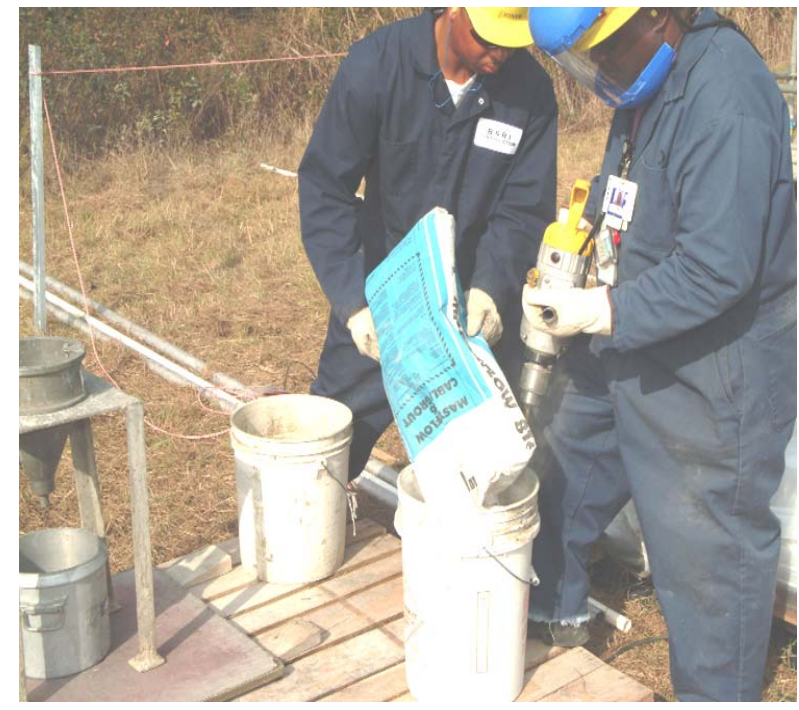

Figure 3-25. Equipment/riser grout mixing.

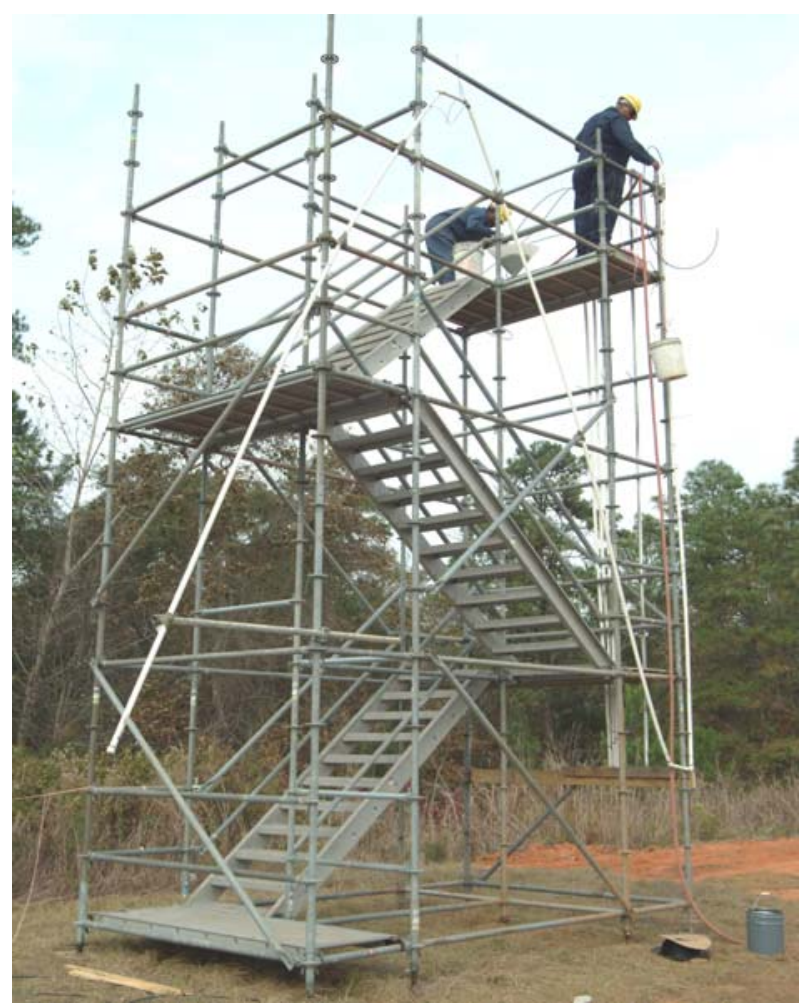

Figure 3-27. Equipment/riser grout conveyance to top of the form.

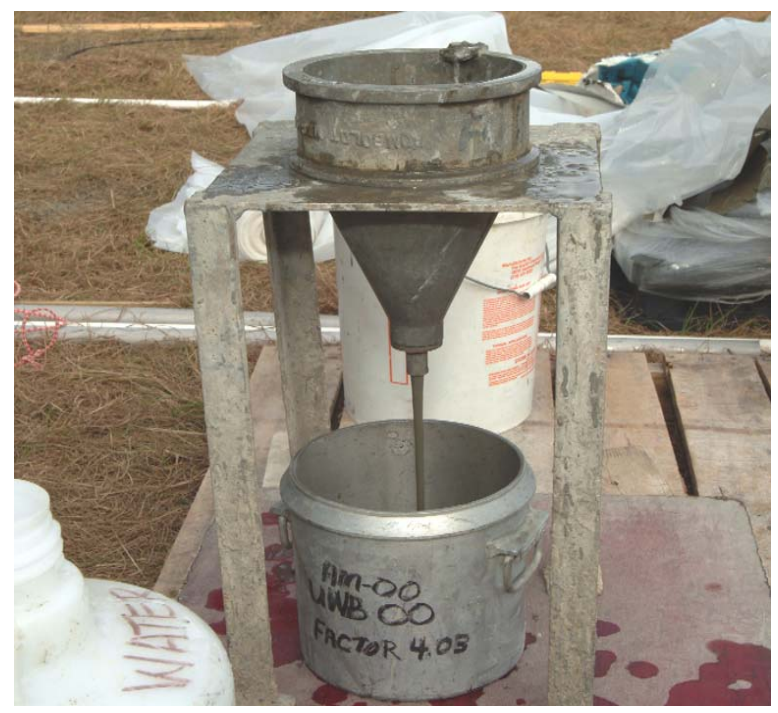

Figure 3-26. Equipment/riser fill grout flow test.

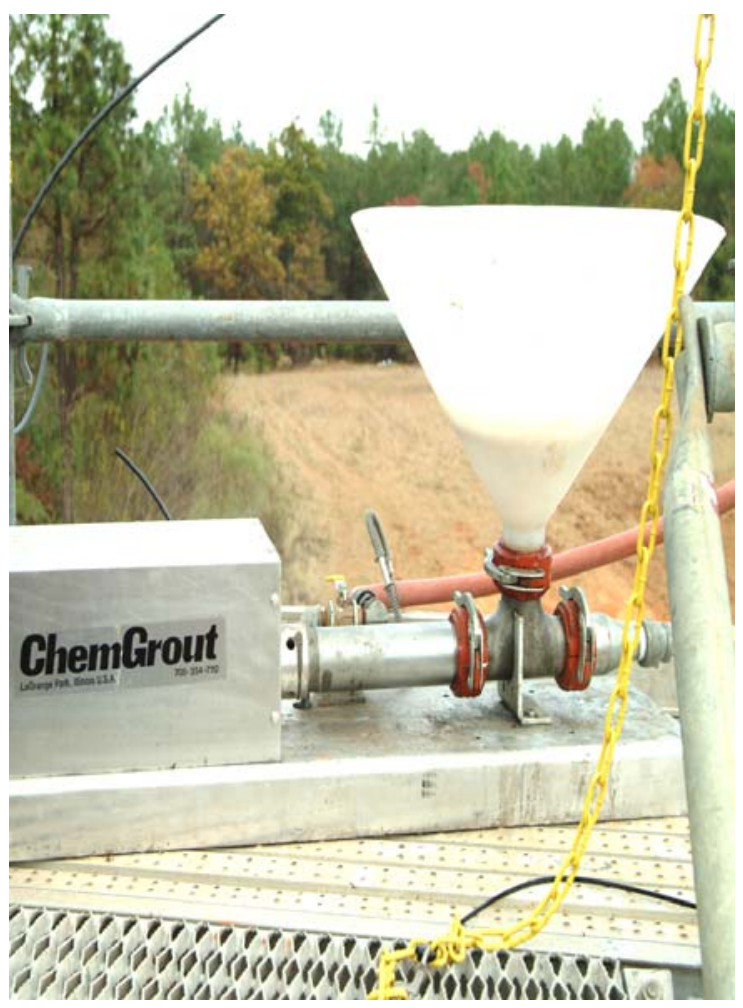

Figure 3-28. Equipment/riser grout funnel hopper which contained a screen to remove lumps prior to pumping. 


\subsubsection{Grout Quality Control}

Batch tickets (weight of each ingredient) were reviewed prior to accepting each delivery. Final reported mix compositions were recorded after water and admixture adjustments were made. Samples of each batch were collected and taken to the on-site Civil Engineering Laboratory where they were cast into various forms and cured for compressive strength measurements. WGI Quality Programs personnel were responsible for the quality control sampling and measurements.

\subsection{Sample Dismantling and Site Cleanup}

The scale-up testing took place November 10 to 17, 2003. Between November 18 and 20, 2003, the forms were dismantled and the placements were excavated and broken up so the grout could be moved to a location in the landfill that is set aside for concrete. Final site cleanup took place between November 24 and 26, 2003. The dismantling of the trench pours is illustrated in Figures 3-29 and 3-30. Dismantling of the swimming pool forms is shown in Figures 3-31 and 3-32. During the dismantling, samples were collected by SRNL personnel and set aside for further characterization, as required. Figures 3-33 and 3-34.

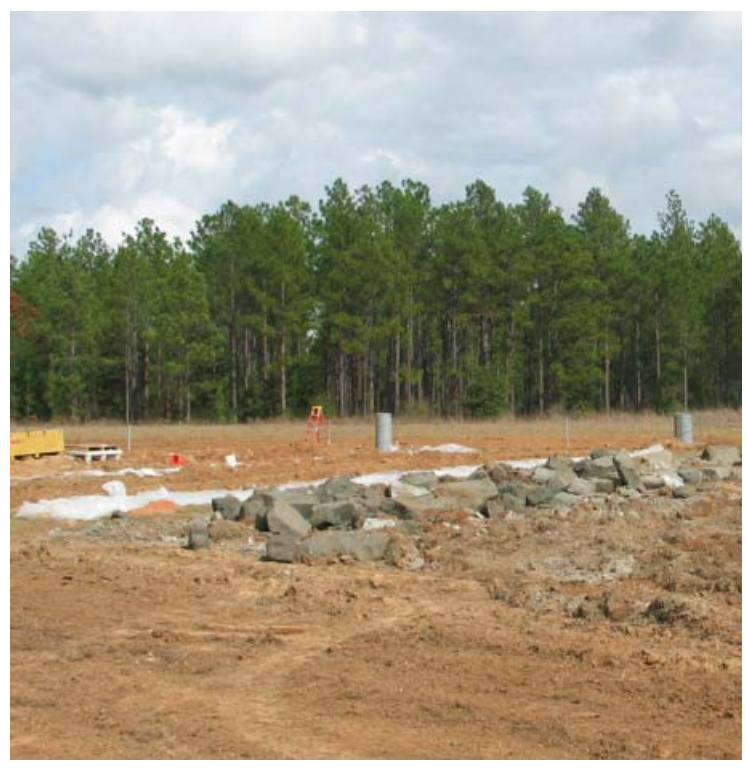

Figure 3-29. Excavation of grout placed in trench forms.

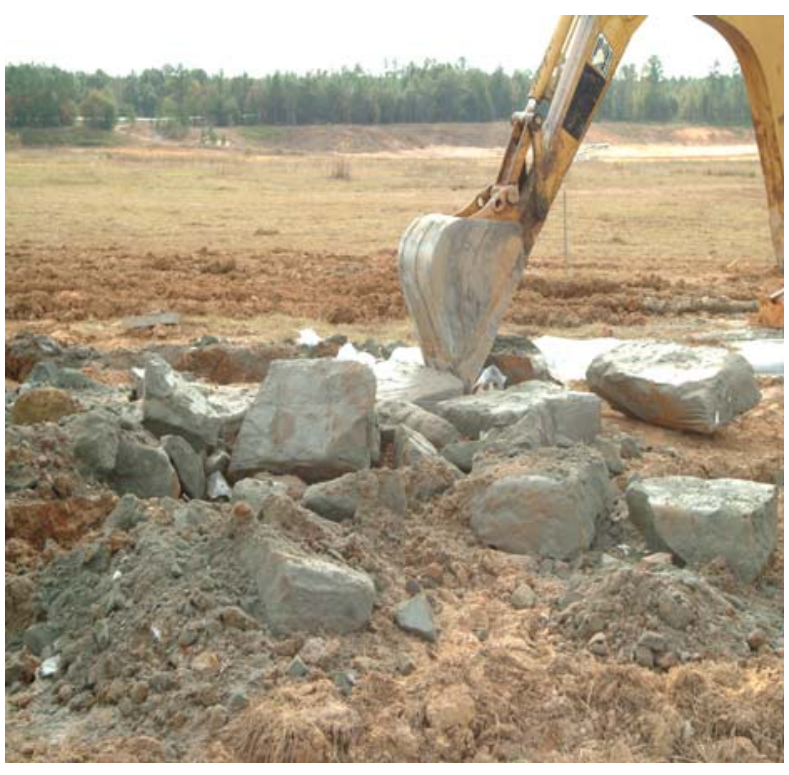

Figure 3-30. Size reduction of the grouts poured in the trench forms after curing for 5 to 10 days. 
WSRC-TR-2003-00556, Rev. 0

December 15, 2003

Page 23 of 55

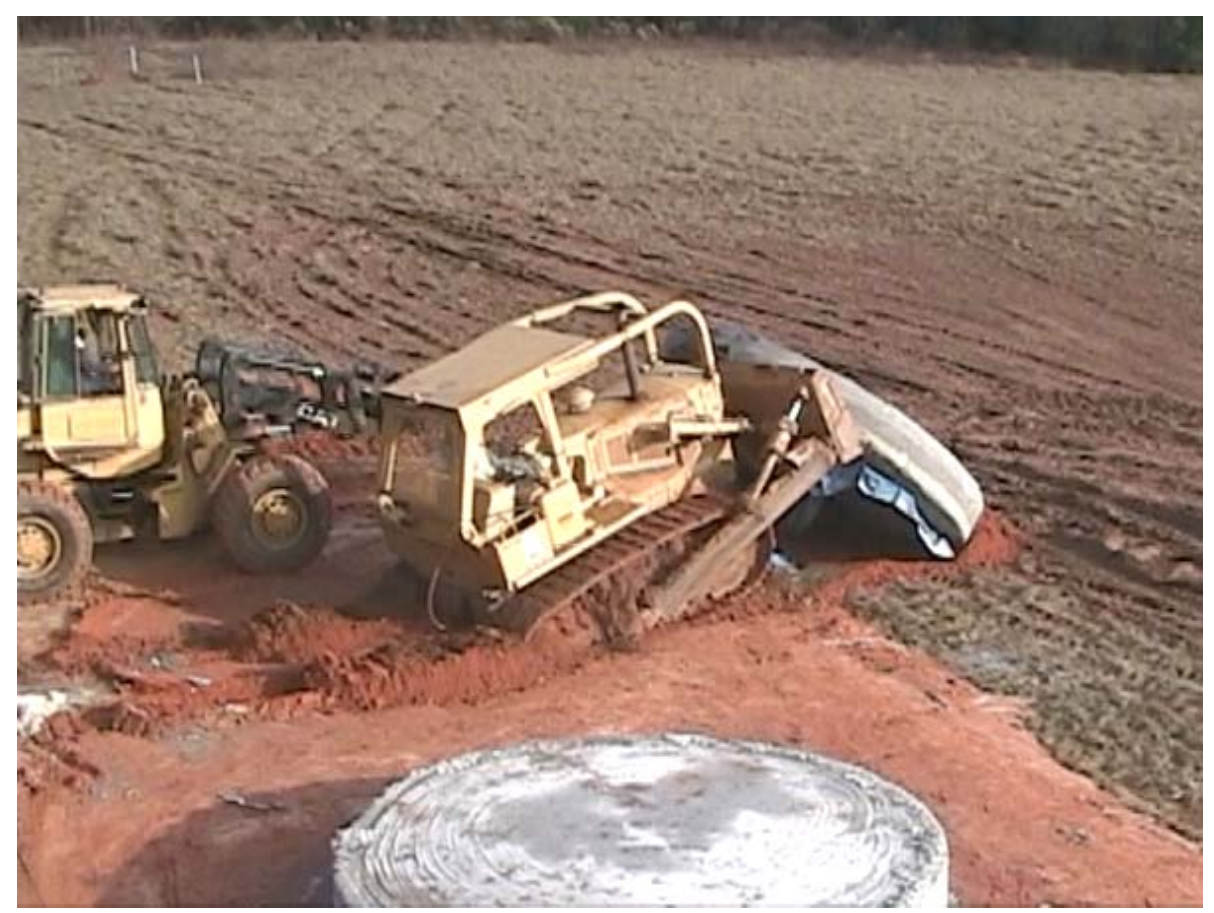

Figure 3-31. Demolition of the pool 1 monolith 5 days after the final Capping Grout pour.

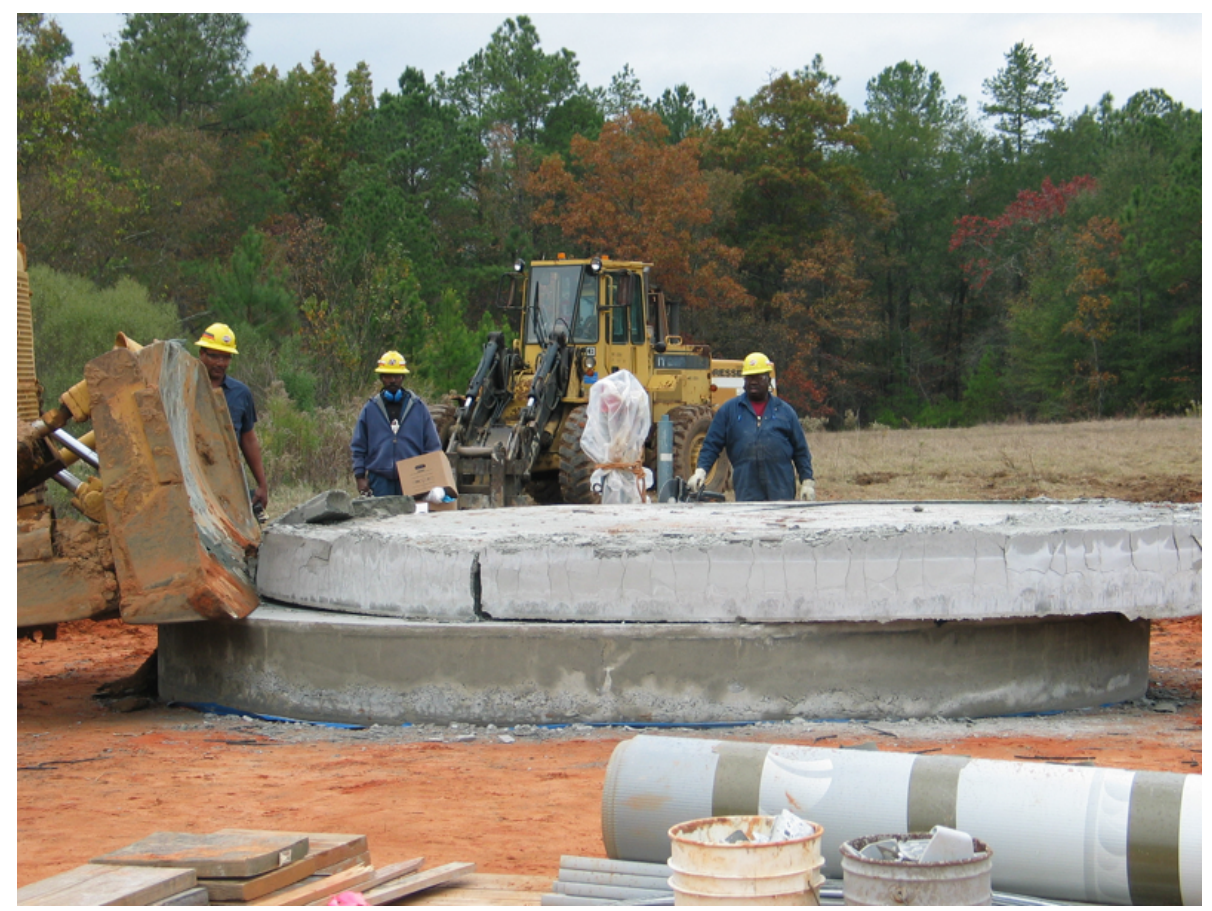

Figure 3-32. Demolition of the pool 2 monolith 5 days after the final Capping Grout pour. 
WSRC-TR-2003-00556, Rev. 0

December 15, 2003

Page 24 of 55

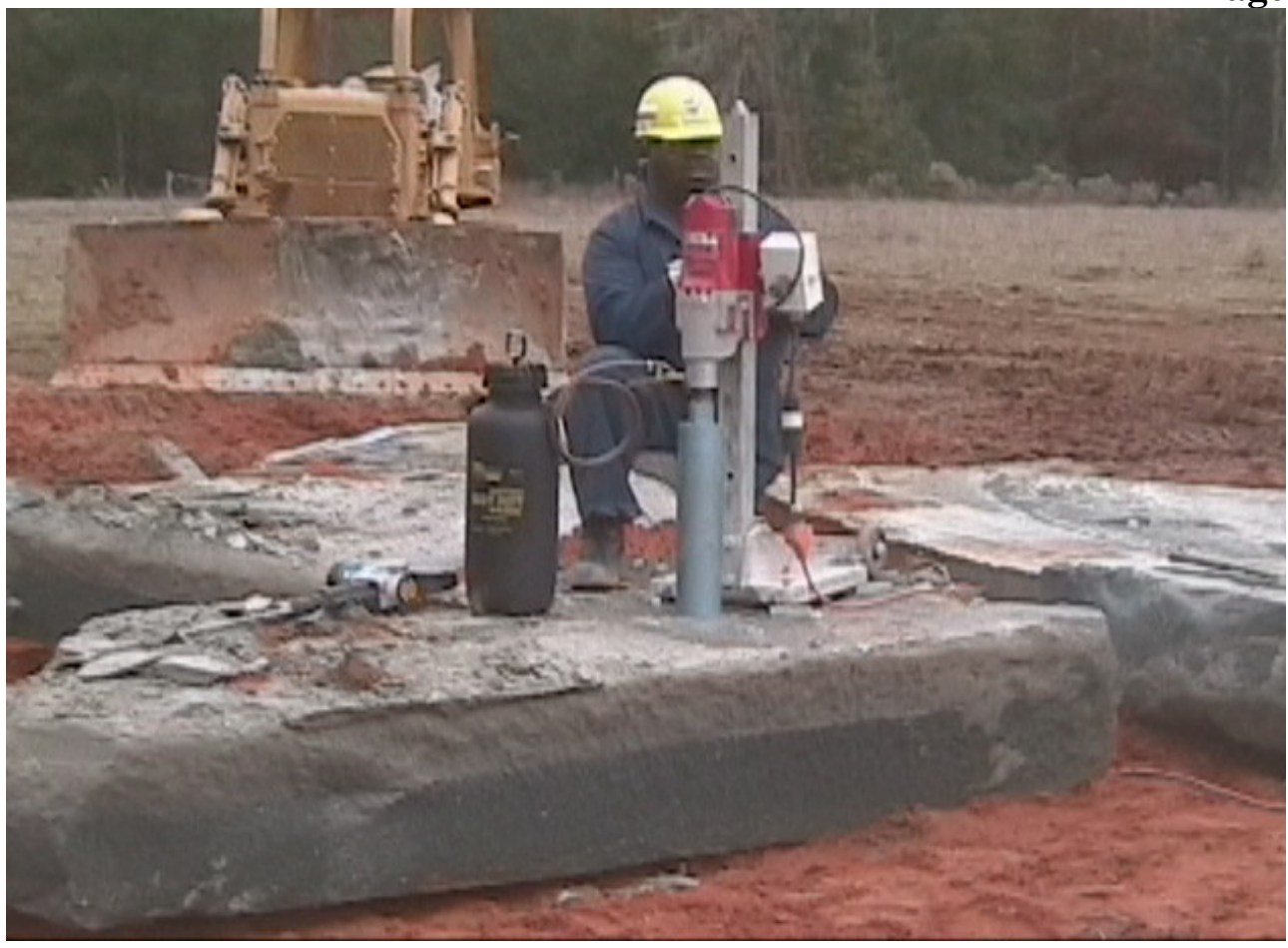

Figure 3-33. Core sampling of Pool 2.

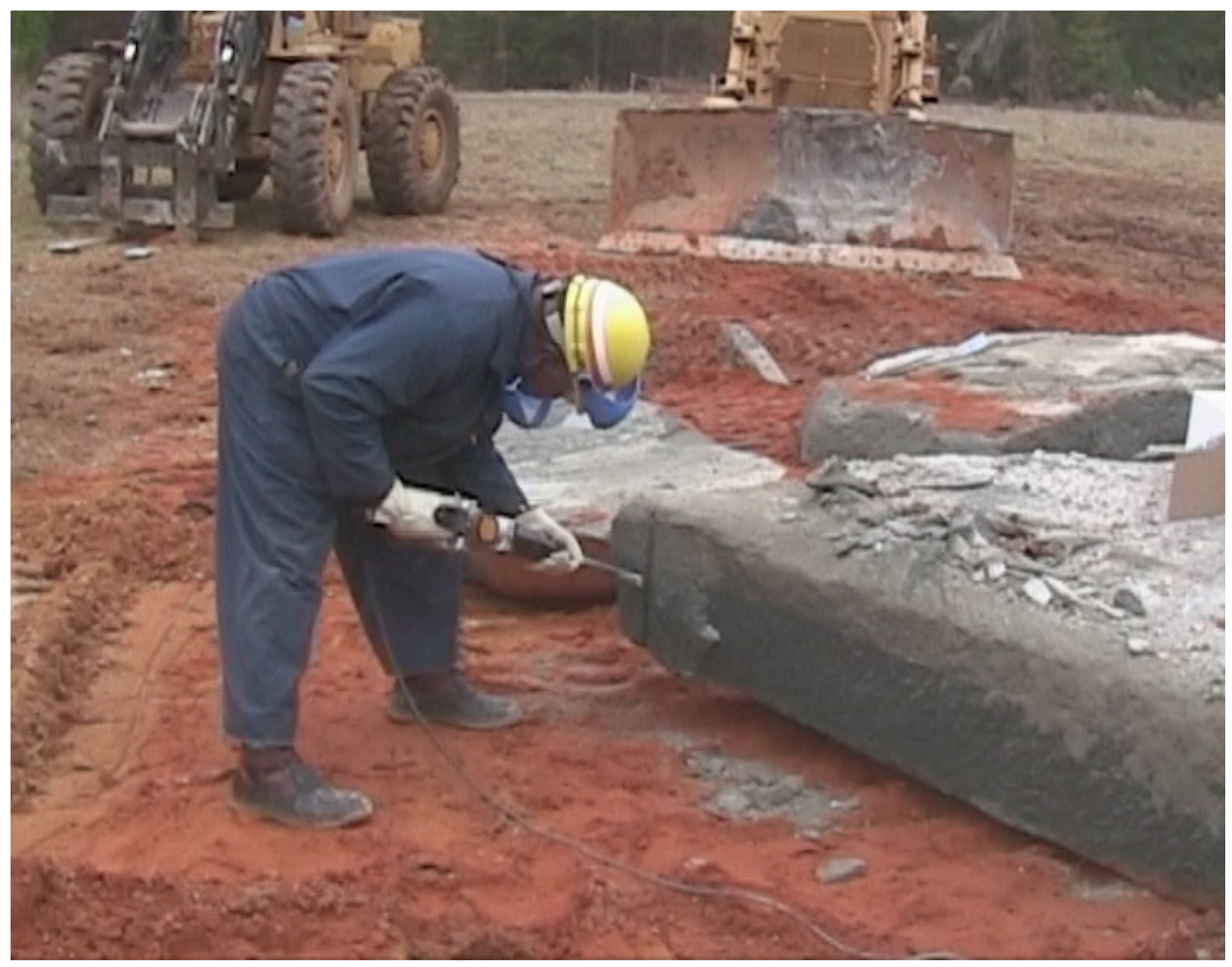

Figure 3-34. Sampling Pool 2 with electric chisel. 


\subsection{RESULTS}

\subsection{Grout Properties}

Placement dates, times, mixes, and forms are summarized in Table 4-1. The batch ticket weights, flowability of each grout after adjustment with water and admixture, and time (less than 90 minutes after batching) were the parameters for accepting each truckload of grout. Results of the flow test, ASTM D-6103, and the general appearance (rolling flow versus separation) were used to make the water and admixture adjustments at the delivery site.

A portion of the mixing water and all of the admixtures were added at the test site. The final mix compositions including the initial mixing water added at the batch plant, additional water added at the test site, and the total mixing water in the mix are listed in Table 4-1. The other fresh properties and cured properties were measured at the onsite Civil Engineering Test Laboratory.

The relative yields (yield compared to the laboratory prepared design mixes) are tabulated in Table 4-2. The yields and relative yields were calculated per ASTM C-138. The material batched for the field tests showed good correlation with the expected volumes.

\subsection{Flow in Trenches 1 and 2}

The pour times and volumes and flow distances are listed in Table 4-3. Before the first pour in each trench, the elevation of the bottom was measured and elevation stakes were placed every 20 feet along the trench. After each pour was complete, the thickness of the fresh grout was measured and the surface elevations were recorded in Tables 4-4 and 4-5. A cross section through the long axis of Trench 1 is shown in Figure 4-1. A cross section through the long axis of Trench 2 is shown in Figure 4-2.

All three placements in Trench 1 were from the discharge shoot on the concrete truck directly into the trench. The drop height varied from about 3 feet to 2 feet for each pour. Grouts were placed in Trench 1 from a discharge point within 5 feet of the south end of the form. The placements were made in the same order as intended for filling an actual waste tank: Phase 1 Grout, the Stabilizing Grout, was placed first, Phase 2 Grout, the Structural Grout next, and Phase 3 Grout, the Capping Grout, was placed last. See Figures 4-3 to 4-6.

The Phase 1 Stabilizing Grout was placed in Trench 2 at one end of the trench using the truck discharge method to demonstrate that flow over 75 feet was feasible. The Phase 2 Structural Grout was placed from the north end of the Trench 2 through a 5-inch slick line 250 feet long to demonstrate pumpability and 75-foot flow. The Phase 3 Capping Grout was placed/pumped through the 5-inch slick line positioned approximately in the middle of the 80-foot long trench to demonstrate 40 -foot bi-directional flow to each end of the trench (equal volumes in each half of the trench). See Figures 4-7 to 4-10. 
WSRC-TR-2003-00556, Rev. 0

December 15, 2003

Page 26 of 55

Table 4-1. Property measurements for mixes prepared for the scale-up test.

\begin{tabular}{|c|c|c|c|c|c|c|c|c|c|c|c|c|c|c|c|c|c|c|c|c|}
\hline Date & & \begin{tabular}{|l|} 
Truck \\
\end{tabular} & & & \multirow{2}{*}{\multicolumn{3}{|c|}{ Placement }} & \begin{tabular}{|l} 
Lab \\
\end{tabular} & Water as & Water* & Total & Admix & & Air & Mix & Bleed & Set & \multirow{2}{*}{\multicolumn{3}{|c|}{$\begin{array}{l}\text { Compressive } \\
\text { Strength (psi) }\end{array}$}} \\
\hline Nov. & Batch & Arrival & Truck & Grout & & & & Sample & delivered & Addition & Water $^{\#}$ & Addition & Flow & temp & temp & Water & time & & & \\
\hline 2003 & Time & Time & No. & Mix & \multicolumn{2}{|c|}{ Location } & Method & No. & (gal/cyd) & (gal/cyd) & (gal/cyd) & $* *$ & (inches) & $(\mathrm{F})$ & (F) & @ 24 hr & (hr) & $14 d$ & $28 \mathrm{~d}$ & 90d \\
\hline 10 & $7: 31$ & 8:00 & 1 & SRG4 & Trench 1 & end & truck & 123 & 43 & 14 & 70 & 1.5 & 14.75 & NA & NA & 0 & $<24$ & 890 & 1,840 & 3,300 \\
\hline 10 & $10: 35$ & $11: 04$ & 2 & SRG2 & Trench 1 & end & truck & 124 & 35 & 11 & 60 & 1.5 & 13.75 & 64 & NA & 0 & $<24$ & 820 & 1,700 & 2,720 \\
\hline 10 & $13: 21$ & $13: 50$ & 3 & SRG9 & Trench 1 & end & truck & 125 & 43 & 14 & 70 & 1.5 & 14 & 67 & 69 & 0 & $<24$ & 1,040 & 2,100 & 3,620 \\
\hline 11 & $7: 29$ & $7: 56$ & 4 & SRG4 & Trench 2 & end & truck & 126 & 45 & 10 & 66 & 1 & 14 & 68 & 59 & 0.8 vol\% & $<24$ & 960 & 1,740 & 3,190 \\
\hline 11 & $9: 43$ & $10: 05$ & 5 & SRG2 & Trench 2 & end & slick line & 127 & 37 & 12 & 61 & 1.5 & 13.75 & 71 & 65 & 0 & $<24$ & 860 & 1,750 & 2,650 \\
\hline 11 & $11: 57$ & $12: 19$ & 6 & SRG9 & Trench 2 & center & \begin{tabular}{|l|} 
slick line \\
\end{tabular} & 128 & 45 & 12 & 68 & 1.5 & 14.25 & 77 & 73 & 0 & $<24$ & 820 & 1,500 & 2,650 \\
\hline 11 & $14: 23$ & $14: 48$ & 7 & SRG4 & S. Pool 1 & center & \begin{tabular}{|l|} 
slick line \\
\end{tabular} & 129 & 45 & 2 & 59 & 1 & 13.5 & 77 & 74 & 0 & $<24$ & 1,030 & 1,840 & 3,220 \\
\hline 12 & $11: 21$ & $11: 39$ & 8 & SRG4 & S. Pool 1 & center & slick line & 130 & 43 & 3 & 60 & 1 & 15 & 83 & 75 & 0.6 vol\% & $<24$ & 960 & 1,710 & 2,940 \\
\hline 12 & $13: 15$ & $13: 37$ & 9 & SRG4 & S. Pool 2 & center & \begin{tabular}{|l|} 
slick line \\
\end{tabular} & 131 & 43 & 3 & 60 & 1 & 13.5 & 85 & 77 & 0 & $<24$ & 1,080 & 1,970 & 3,590 \\
\hline 13 & $7: 15$ & $7: 30$ & 10 & SRG2 & S. Pool 1 & center & slick line & 132 & 38 & 3 & 51 & $7 / 6$ & 13 & 66 & 64 & 0 & $<24$ & 1,030 & 2,450 & 3,530 \\
\hline 13 & $9: 25$ & $10: 00$ & 11 & SRG2 & S. Pool 2 & center & \begin{tabular}{|l|} 
slick line \\
\end{tabular} & 133 & 38 & 6 & 55 & $7 / 6$ & 13 & 68 & 65 & 0 & $<24$ & 750 & 1,750 & 2,500 \\
\hline 13 & $12: 49$ & $13: 19$ & 12 & SRG9 & \begin{tabular}{|c|} 
Culvert \\
1
\end{tabular} & center & \begin{tabular}{|c|} 
pump \\
vert. pipe
\end{tabular} & 134 & 46 & 7 & 62 & 1 & 13.5 & 77 & 67 & $1.4 \mathrm{vol} \%$ & $<24$ & 1,240 & 2,500 & 4,030 \\
\hline 13 & & & & SRG9 & Trench 3 & \begin{tabular}{|c|} 
end \\
$2 \mathrm{ft}$ drop \\
\end{tabular} & Pump & & & & & & & & & & & & & \\
\hline 17 & $12: 31$ & $12: 55$ & 13 & SRG9 & S. Pool 1 & center & slick line & 135 & 47 & 2 & 58 & 1 & 12.5 & 88 & 75 & 0 & $<24$ & 1,100 & 2,280 & 3,820 \\
\hline 17 & & & & SRG9 & S. Pool 2 & center & \begin{tabular}{|l} 
slick line \\
\end{tabular} & & & & & & & & & & & & & \\
\hline 17 & $14: 36$ & $14: 50$ & 14 & SRG9 & Trench 3 & $\begin{array}{c}\text { end } \\
10 \mathrm{ft} \\
\text { drop }\end{array}$ & \begin{tabular}{|l|} 
slick line \\
\end{tabular} & 136 & 47 & 3 & 59 & 1 & 13 & 90 & 75 & 0.7 vol\% & $<24$ & 1,050 & 2,170 & 3,610 \\
\hline 18 & $9: 38$ & $10: 00$ & 15 & $\begin{array}{c}\text { SRG } \\
9\end{array}$ & \begin{tabular}{|c|} 
Culvert \\
2
\end{tabular} & center & \begin{tabular}{|c|} 
pump \\
vert. pipe
\end{tabular} & 137 & 45 & 0 & 56 & 1.5 & 11 & 78 & 74 & 0 & $<24$ & 1,560 & 2,760 & 4,140 \\
\hline
\end{tabular}

* Some of the water and the entire amount of the premixed admixture system specified for each mix were held back at the batch plant. Final adjustments to fluidify the grouts were required at the job site. ** The amount of admixture is designated as a factor times the design amount which was a blend of 90 fluid ounces of ADVA Flow and $275 \mathrm{~g}$ of Kelco-Crete per cubic yard.

\# Total water includes: water added as mixing water at the batch plant, water added to the truck batch at the delivery site, and free water in the sand. The amount sand is shown in Table 3-7. The free water in the sand in each truck is listed. Trucks $1-3=5.0$ wt $\%$, Trucks $4-7=4.1$ wt. $\%$, Trucks 8 and $9=$ wt. $\%$, Trucks $10-12=3.8$ wt. $\%$, Trucks 13 and $14=3.4$ wt. $\%$, and Truck $15=3.9$ wt. $\%$. 
WSRC-TR-2003-00556, Rev. 0 December 15, 2003

Page 27 of 55

Table 4-2. Water and admixture contents and unit weights/yields of the grouts prepared for the scale-up testing.

\begin{tabular}{|c|c|c|c|c|c|c|c|c|c|c|c|c|c|}
\hline \multirow{2}{*}{$\begin{array}{l}\text { Grout } \\
\text { Mix }\end{array}$} & \multirow{2}{*}{$\begin{array}{c}\text { Amount } \\
\text { Received } \\
\text { cyd } \\
\end{array}$} & \multicolumn{3}{|c|}{ Placement } & \multicolumn{2}{|c|}{$\begin{array}{c}\text { Total Water } \\
\text { Per cubic yard }\end{array}$} & \multirow{2}{*}{$\begin{array}{c}\text { Total } \\
\text { Admix }^{*} \\
\text { (factor) }\end{array}$} & \multirow{2}{*}{$\begin{array}{c}\begin{array}{c}\text { Empty } \\
\text { Container }\end{array} \\
\text { (lbs) }\end{array}$} & \multirow{2}{*}{$\begin{array}{c}\text { Container } \\
+ \text { Grout }\end{array}$} & \multirow{2}{*}{$\begin{array}{l}\text { Volume } \\
\text { Factor } \\
\text { (factor) }\end{array}$} & \multirow{2}{*}{$\begin{array}{c}\text { Field } \\
\text { Unit Wt. }^{\#} \\
\text { (lbs/cft) }\end{array}$} & \multirow{2}{*}{$\begin{array}{c}\text { Laboratory } \\
\text { Unit Wt. }^{*} \\
\text { (lbs/cft) }\end{array}$} & \multirow{2}{*}{$\begin{array}{c}\begin{array}{c}\text { Relative } \\
\text { Yield }^{\#}\end{array} \\
\mathrm{R}_{\mathrm{y}}=\mathrm{Y}_{\mathrm{F}} / \mathrm{Y}_{\mathrm{D}}\end{array}$} \\
\hline & & Location & & Method & (lbs) & (gallons) & & & & & & & \\
\hline SRG4 & 7 & Trench 1 & End & Truck & 583.1 & 70 & $1.5 \mathrm{X}$ & 7.89 & 39.3 & 4.03 & 126.6 & 124.5 & 1.02 \\
\hline SRG2 & 7 & Trench 1 & End & Truck & 501.6 & 60 & $1.5 \mathrm{X}$ & 7.89 & 38.26 & 4.03 & 122.4 & 122.2 & 1.00 \\
\hline SRG9 & 7 & Trench 1 & End & Truck & 580.2 & 70 & $1.5 \mathrm{X}$ & 7.89 & 39 & 4.03 & 125.4 & 126.1 & 0.99 \\
\hline SRG4 & 7 & Trench 2 & End & Truck & 551.6 & 66 & $1 \mathrm{X}$ & 7.94 & 39.35 & 4.03 & 126.6 & 124.5 & 1.02 \\
\hline SRG2 & 7 & Trench 2 & End & Slick Line & 506.4 & 61 & $1.5 \mathrm{X}$ & 7.94 & 38.2 & 4.03 & 121.9 & 122.2 & 1.00 \\
\hline SRG9 & 7 & Trench 2 & Center & Slick Line & 570.7 & 68 & $1.5 \mathrm{X}$ & 7.94 & 39.12 & 4.03 & 125.7 & 126.1 & 1.00 \\
\hline SRG4 & 7 & S. Pool 1 & Center & Slick Line & 488.5 & 59 & $1 \mathrm{X}$ & 7.94 & 39.22 & 4.03 & 126.1 & 124.5 & 1.01 \\
\hline SRG4 & 7 & S. Pool 1 & Center & Slick Line & 496.8 & 60 & $1 \mathrm{X}$ & 7.9 & 38.92 & 4.03 & 125.0 & 124.5 & 1.00 \\
\hline SRG4 & 7 & S. Pool 2 & Center & Slick Line & 496.8 & 60 & $1 \mathrm{X}$ & 7.9 & 39.37 & 4.03 & 126.8 & 124.5 & 1.02 \\
\hline SRG2 & 6 & S. Pool 1 & Center & Slick Line & 426.7 & 51 & $7 / 6 \mathrm{X}$ & 7.95 & 38.75 & 4.03 & 124.1 & 122.2 & 1.02 \\
\hline SRG2 & 6 & S. Pool 2 & Center & Slick Line & 454.5 & 55 & $7 / 6 \mathrm{X}$ & 7.95 & 38.93 & 4.03 & 124.8 & 122.2 & 1.02 \\
\hline SRG9 & 7 & Culvert 1 & Center & Pump & \multirow[t]{2}{*}{514.7} & \multirow[t]{2}{*}{62} & \multirow[t]{2}{*}{$1 \mathrm{X}$} & \multirow[t]{2}{*}{7.95} & \multirow[t]{2}{*}{39.83} & \multirow[t]{2}{*}{4.03} & \multirow[t]{2}{*}{128.5} & \multirow[t]{2}{*}{126.1} & \multirow[t]{2}{*}{1.02} \\
\hline SRG9 & 7 & Trench 3 & End & Pump & & & & & & & & & \\
\hline SRG9 & 7 & S. Pool 1 & Center & Slick Line & \multirow[t]{2}{*}{486.1} & \multirow[t]{2}{*}{58} & \multirow[t]{2}{*}{$1 \mathrm{X}$} & \multirow[t]{2}{*}{8.12} & \multirow[t]{2}{*}{40.1} & \multirow{2}{*}{$\begin{array}{l}4.03 \\
4.03\end{array}$} & \multirow[t]{2}{*}{128.9} & \multirow[t]{2}{*}{126.1} & \multirow[t]{2}{*}{1.02} \\
\hline SRG9 & 7 & S. Pool 2 & Center & Slick Line & & & & & & & & & \\
\hline SRG9 & 7 & Trench 3 & End & Slick Line & 493.3 & 59 & $1 \mathrm{X}$ & 8.12 & 40.79 & 4.03 & 131.7 & 126.1 & 1.04 \\
\hline SRG9 & 3 & Culvert 2 & Center & Slick Line & 469.8 & 56 & $1.5 \mathrm{X}$ & 8.12 & 39.21 & 4.03 & 125.3 & 126.1 & 0.99 \\
\hline
\end{tabular}

* The amount of admixture is designated as a factor times the design amount which was a blend of 90 fluid ounces of ADVA Flow and $275 \mathrm{~g}$ of Kelco-Crete per cubic yard.

\# Theoretical design unit weights are reported elsewhere [5] and were calculated based on the unit weights of all of the ingredients. These calculations were used to develop the trial mixes.

The Laboratory Unit Weights for SRG2 and 9 measured on mixes prepared in the lab are documented elsewhere [5]. The Lab Unit Weight for SRG 4 was measured on laboratory samples and recorded in WSRC-NB-2003-00192.

The Field Unit Weights were measured using mixes prepared in the field for the scale-up testing.

Yield is the measured unit weight compared to the theoretical unit weight. The relative yield, $\mathrm{R}_{\mathrm{y}}$, is calculated by dividing the Field Yield by the Laboratory Yield as follows:

(Field Unit Wt. / Theoretical Unit Wt $) \div($ Laboratory Unit Wt. / Theoretical Unit Wt.) $=$ (Field Unit Weight $\div$ Laboratory Unit Weight). 
WSRC-TR-2003-00556, Rev. 0

December 15, 2003

Page 28 of 55

Table 4-3. Placement results for the scale-up test.

\begin{tabular}{|c|c|c|c|c|c|c|c|}
\hline $\begin{array}{c}\text { Trench } \\
\text { (Discharge } \\
\text { Point) } \\
\end{array}$ & $\begin{array}{l}\text { Grout } \\
\text { Mix }\end{array}$ & $\begin{array}{c}\text { Flow } \\
\text { distance } \\
(\mathrm{ft})\end{array}$ & $\begin{array}{c}\text { Pour time } \\
\text { (minutes: sec) }\end{array}$ & $\begin{array}{l}\text { Amount } \\
\text { (cyd) }\end{array}$ & $\begin{array}{l}\text { Ave. Pour Rate } \\
\text { (cyd/min.) }\end{array}$ & $\begin{array}{l}\text { Segregation or } \\
\text { Bleed in Trench }\end{array}$ & Observations \\
\hline $\begin{array}{c}1 \\
\text { (end) }\end{array}$ & SRG 4 & 75 & $1: 15$ & 5.9 & 4.7 & None & Self leveling \\
\hline $\begin{array}{c}1 \\
\text { (end) }\end{array}$ & SRG 2 & 75 & $0: 50$ & 5.5 & 6.6 & None & Self leveling \\
\hline $\begin{array}{c}1 \\
\text { (end) }\end{array}$ & SRG 9 & 75 & $0: 55$ & 6.4 & 6.9 & None & $\begin{array}{l}\text { Long hold time after } \\
\text { final adjustment due } \\
\text { to equipment } \\
\text { malfunctions, about } \\
\text { 1cubic yard of grout } \\
\text { lost in attempted } \\
\text { slick line placement }\end{array}$ \\
\hline $\begin{array}{c}2 \\
\text { (end) }\end{array}$ & SRG 4 & 75 & $1: 10$ & 6.6 & 5.7 & Trace & Self leveling \\
\hline $\begin{array}{c}2 \\
\text { (end) }\end{array}$ & SRG 2 & 75 & $3: 45$ & 4.1 & 1.1 & None & $\begin{array}{l}\text { Long hold time after } \\
\text { final adjustment due } \\
\text { to equipment } \\
\text { malfunctions. Slow } \\
\text { pour rate resulted in } \\
\text { sloped surface. }\end{array}$ \\
\hline $\begin{array}{c}2 \\
\text { (near center) }\end{array}$ & SRG 9 & 40 & $3: 30$ & 3.9 & 1.1 & None & Self leveling \\
\hline
\end{tabular}


WSRC-TR-2003-00556, Rev. 0 December 15, 2003

Page 29 of 55

Table 4-4. Trench 1 pour thickness and surface elevation data.

\begin{tabular}{|c|c|c|c|c|c|c|c|c|c|c|c|c|c|c|}
\hline \multicolumn{5}{|c|}{ Empty Trench 1* } & \multicolumn{4}{|c|}{ Pour \#1** } & \multicolumn{4}{|c|}{ Pour \#2** } & \multicolumn{2}{|c|}{ Pour \#3** } \\
\hline $\begin{array}{c}\text { Stake } \\
\text { Location } \\
(\mathrm{ft}) \\
\end{array}$ & $\begin{array}{c}\text { Ground } \\
\text { Level } \\
(\mathrm{ft})\end{array}$ & $\begin{array}{l}\begin{array}{c}\text { Delta } \\
\text { from } \\
0 \text { Stake } \\
\text { (in) }\end{array} \\
\end{array}$ & $\begin{array}{c}\text { Trench } \\
\text { Bottom } \\
\text { Level } \\
(\mathrm{ft})\end{array}$ & $\begin{array}{c}\begin{array}{c}\text { Delta } \\
\text { from }\end{array} \\
0 \text { Stake } \\
\text { (in) }\end{array}$ & $\begin{array}{c}\text { Grout } \\
\text { Level } \\
(\mathrm{ft}) \\
\end{array}$ & $\begin{array}{c}\text { Delta } \\
\text { from } \\
0 \text { Stake } \\
\text { (in) }\end{array}$ & $\begin{array}{c}\text { Grout } \\
\text { Depth } \\
\text { (in) } \\
\end{array}$ & $\begin{array}{c}\text { Delta } \\
\text { from } 0 \\
\text { Stake } \\
\text { (in) } \\
\end{array}$ & $\begin{array}{c}\text { Grout } \\
\text { Level } \\
(\mathrm{ft}) \\
\end{array}$ & $\begin{array}{c}\begin{array}{c}\text { Delta } \\
\text { from }\end{array} \\
0 \text { Stake } \\
\text { (in) }\end{array}$ & $\begin{array}{l}\text { Grout } \\
\text { Depth } \\
\text { (in) } \\
\end{array}$ & $\begin{array}{c}\text { Delta } \\
\text { from } \\
0 \text { Stake } \\
\text { (in) }\end{array}$ & $\begin{array}{c}\text { Grout } \\
\text { Depth } \\
\text { (in) }\end{array}$ & $\begin{array}{c}\text { Delta } \\
\text { From } 0 \\
\text { Stake } \\
\text { (in) } \\
\end{array}$ \\
\hline 0 & 3.55 & 0 & 7.08 & 0 & 7.4 & 0 & 11 & 0 & 6.35 & 0 & 13.5 & 0 & & \\
\hline 10 & 3.5 & -0.6 & 7.05 & -0.36 & & & & & & & & & 19 & 0 \\
\hline 20 & 3.68 & 1.56 & 7.02 & -0.72 & 7.8 & -0.24 & 13 & 2 & 6.43 & 0.96 & 13 & -0.5 & 15 & -4 \\
\hline 30 & 3.66 & 1.32 & 6.98 & -1.2 & & & & & & & & & & \\
\hline 40 & 3.68 & 1.56 & 7.02 & -0.72 & 7.42 & 0.24 & 10.5 & -0.5 & 6.48 & 1.56 & 12 & -1.5 & 11 & -8 \\
\hline 50 & 3.65 & 1.2 & 7.03 & -0.6 & & & & & & & & & & \\
\hline 60 & 3.76 & 2.52 & 7.07 & -0.12 & 7.38 & -0.24 & 13 & 2 & 6.57 & 2.64 & 10.5 & -3 & 8 & -11 \\
\hline 70 & 3.8 & 3 & 7.1 & 0.24 & & & & & & & & & & \\
\hline 80 & 3.98 & 5.16 & 7.1 & 0.24 & 7.4 & 0 & 13 & 2 & 6.6 & 3 & 9.5 & 4 & 7 & -12 \\
\hline
\end{tabular}

Table 4-5. Trench 2 pour thickness and surface elevation data.

\begin{tabular}{|c|c|c|c|c|c|c|c|c|c|c|c|c|c|c|c|c|}
\hline \multicolumn{5}{|c|}{ Empty Trench 2* } & \multicolumn{4}{|c|}{ Pour \# 1** } & \multicolumn{4}{|c|}{ Pour \# 2** } & \multicolumn{4}{|c|}{ Pour \#3** } \\
\hline $\begin{array}{c}\text { Stake } \\
\text { (ft) }\end{array}$ & $\begin{array}{c}\text { Ground } \\
\text { Level } \\
\text { (ft) }\end{array}$ & $\begin{array}{c}\text { Delta } \\
\text { from 0 } \\
\text { Stake } \\
\text { (in) }\end{array}$ & $\begin{array}{c}\text { Trench } \\
\text { Bottom } \\
\text { Level } \\
(\mathrm{ft})\end{array}$ & $\begin{array}{l}\text { Delta } \\
\text { from } 0 \\
\text { Stake } \\
\text { (in) }\end{array}$ & $\begin{array}{c}\text { Grout } \\
\text { Level } \\
(\mathrm{ft})\end{array}$ & $\begin{array}{c}\text { Delta } \\
\text { From } 0 \\
\text { Stake } \\
\text { (in) }\end{array}$ & $\begin{array}{r}\text { Grout } \\
\text { Depth } \\
\text { (in) }\end{array}$ & $\begin{array}{l}\text { Delta } \\
\text { From } 0 \\
\text { Stake } \\
\text { (in) }\end{array}$ & $\begin{array}{c}\text { Grout } \\
\text { Level } \\
(\mathrm{ft})\end{array}$ & $\begin{array}{c}\text { Delta } \\
\text { From } 0 \\
\text { Stake } \\
\text { (in) }\end{array}$ & $\begin{array}{l}\text { Grout } \\
\text { Depth } \\
\text { (in) }\end{array}$ & $\begin{array}{l}\text { Delta } \\
\text { From } \\
0 \text { Stake } \\
\text { (in) }\end{array}$ & $\begin{array}{c}\text { Grout } \\
\text { Level } \\
(\mathrm{ft})\end{array}$ & $\begin{array}{l}\text { Delta } \\
\text { From } 0 \\
\text { Stake } \\
\text { (in) }\end{array}$ & $\begin{array}{c}\text { Grout } \\
\text { Depth } \\
\text { (in) }\end{array}$ & $\begin{array}{c}\text { Delta } \\
\text { From } \\
\text { 0 Stake }\end{array}$ \\
\hline 0 & 5.02 & 0 & 8.35 & 0 & 7.1 & 0 & 12.5 & 0 & 6.18 & 0 & 14 & 0 & 5.68 & 0 & 4.5 & 0 \\
\hline 20 & 5.05 & -1.8 & 8.25 & -1.2 & 7.2 & 1.2 & 12 & -0.5 & 6.3 & 1.44 & 12 & -2 & 5.6 & -0.96 & 8.5 & 4 \\
\hline 40 & 5 & -2.4 & 8.26 & -1.08 & 7.25 & 1.8 & 12.5 & 0 & 6.4 & 2.64 & 10 & -4 & 5.57 & -1.32 & $\begin{array}{c}10.2 \\
5\end{array}$ & 5.75 \\
\hline 60 & 4.78 & -5.04 & 8.28 & -0.84 & 7.34 & 2.88 & 14 & 1.5 & 6.55 & 4.44 & 7 & -7 & 5.71 & 0.36 & $\begin{array}{c}10.2 \\
5\end{array}$ & 5.75 \\
\hline 80 & 4.78 & -5.04 & 8.28 & -0.84 & 7.45 & 4.2 & 14 & 1.5 & 6.85 & 8.04 & 2.75 & -11.25 & 5.92 & 2.88 & 11.5 & 7 \\
\hline
\end{tabular}

* Level is determined with a hand level and grade stick. A point is selected adjacent to the center of the trench and the hand level is positioned on a pole. A grade stick is positioned at the different stake locations and the height of the stick parallel to the pivot point is recorded. The readings are in units of feet.

** Actual grout thickness is determined by placing a stick through the layer of grout and measuring the depth in inches with a tape measure. 
WSRC-TR-2003-00556, Rev. 0

December 15, 2003

Page 30 of 55

\section{Trench \# 1}

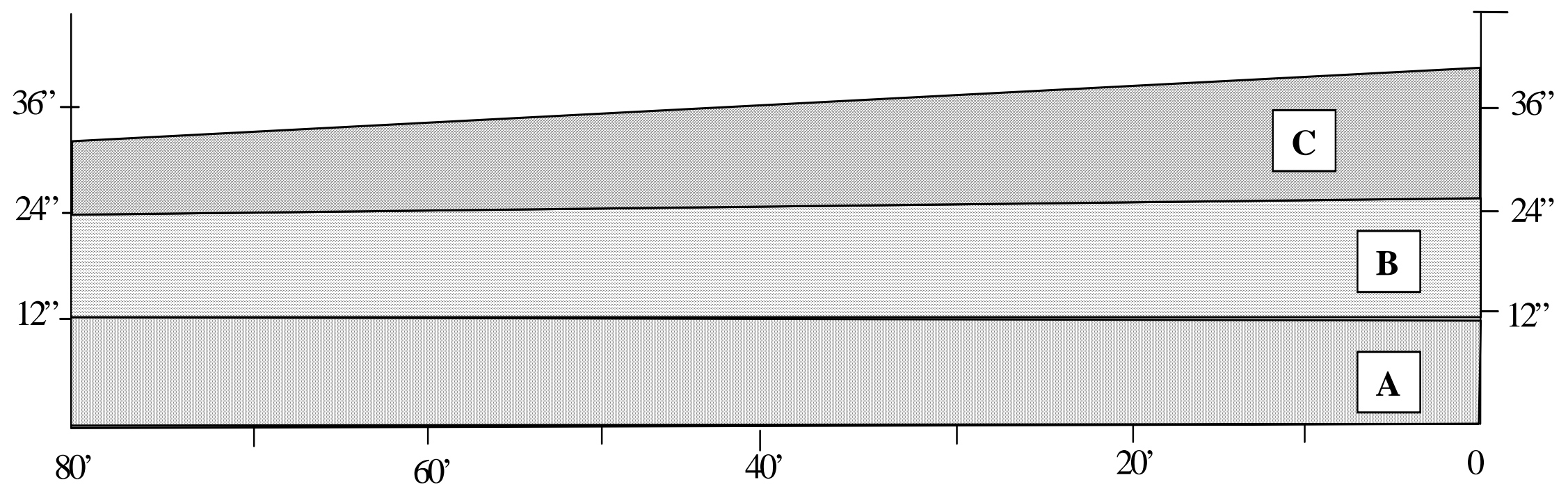

A = SRG4 Stabilizing grout discharge point

$\mathrm{B}=$ SRG 2 Structural grout discharge point

$\mathrm{C}=$ SRG9 Capping grout discharge point

Figure 4-1. Schematic of Trench 1 illustrating the thickness of each placement relative to the discharge point. 
WSRC-TR-2003-00556, Rev. 0

December 15, 2003

Page 31 of 55

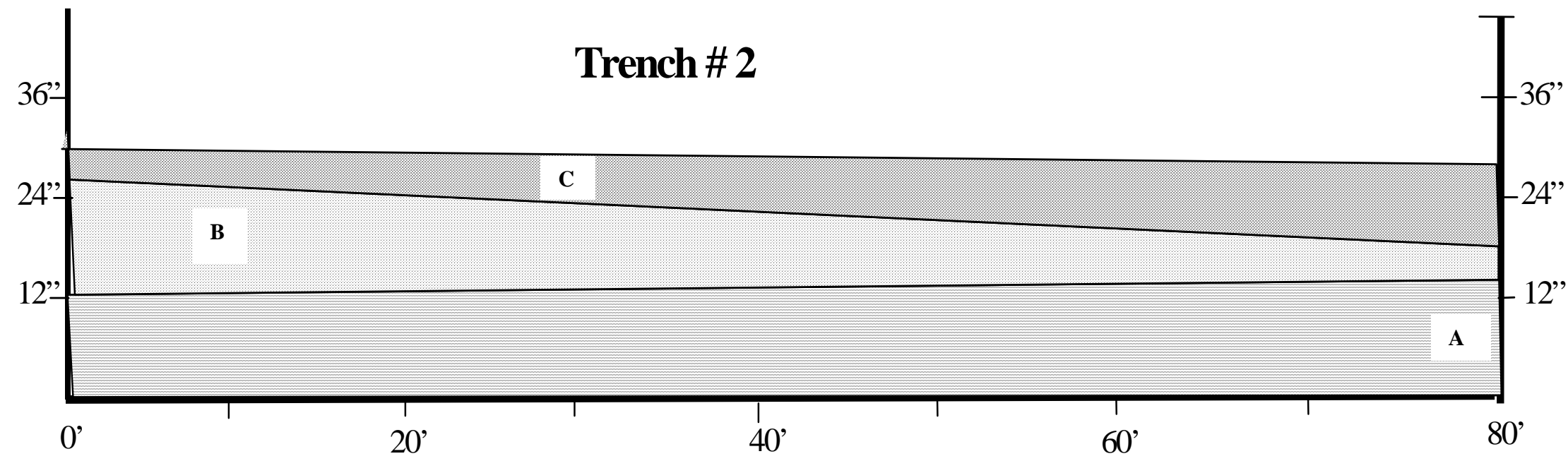

A $=$ SRG4 Stabilizing grout discharge point

$\mathrm{B}=$ SRG 2 Structural grout discharge point

$\mathrm{C}=$ SRG 9 Capping grout discharge point

Figure 4-2. Schematic of Trench 2 illustrating the thickness of each placement relative to the discharge point. 
WSRC-TR-2003-00556, Rev. 0

December 15, 2003

Page 32 of 55

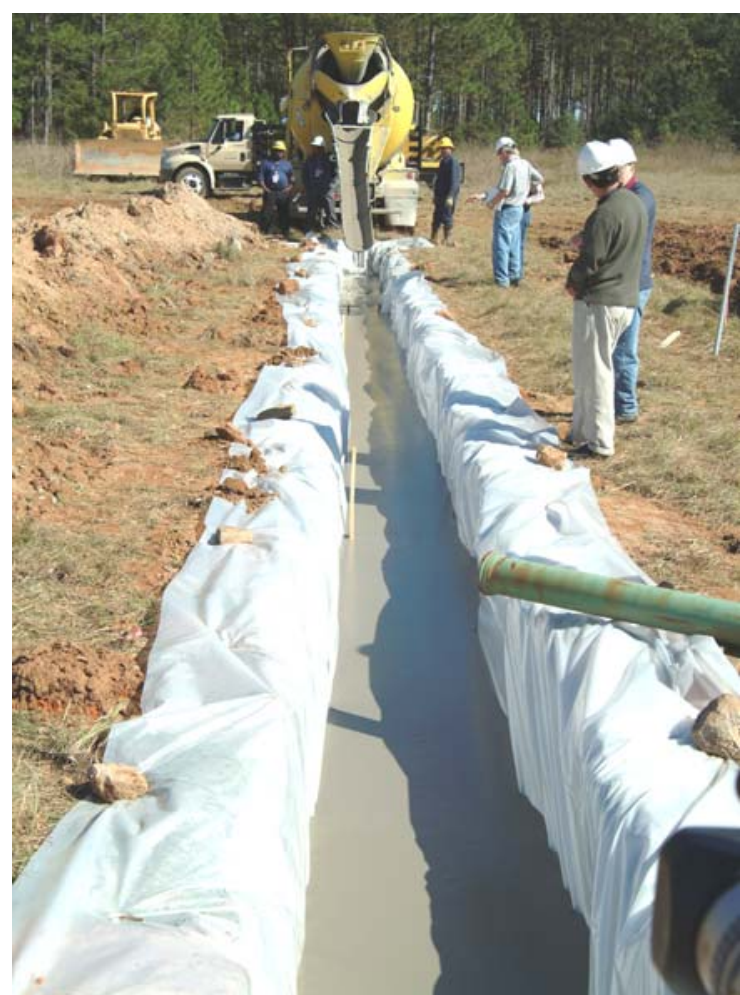

Figure 4-3. Stabilizing grout in Trench 1 immediately after placement.

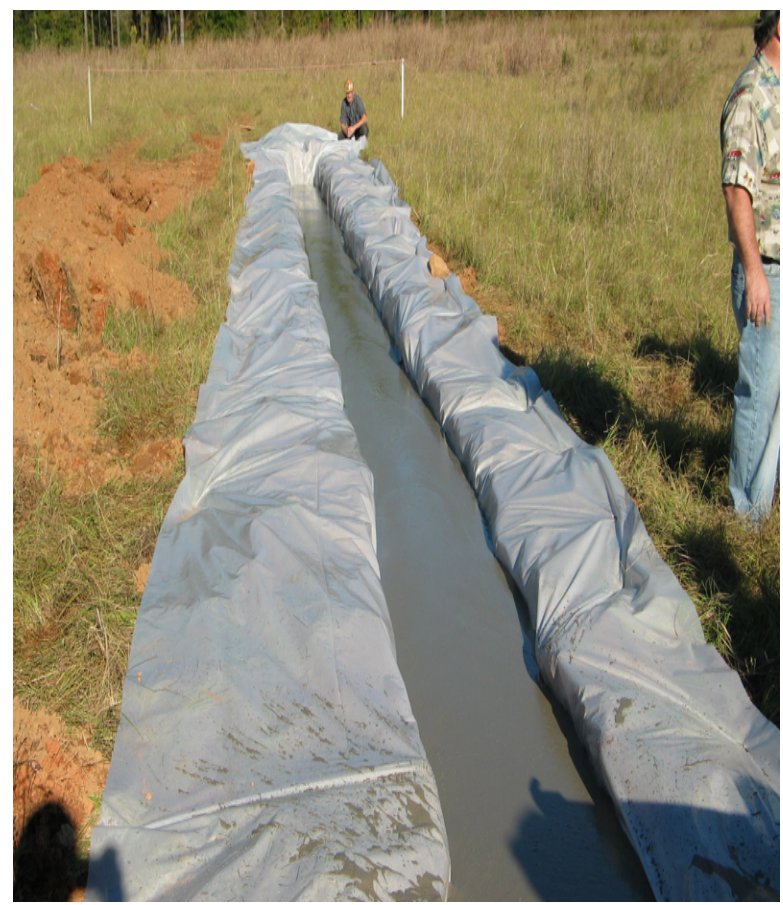

Figure 4-5. Capping grout in Trench 1 immediately after placement.

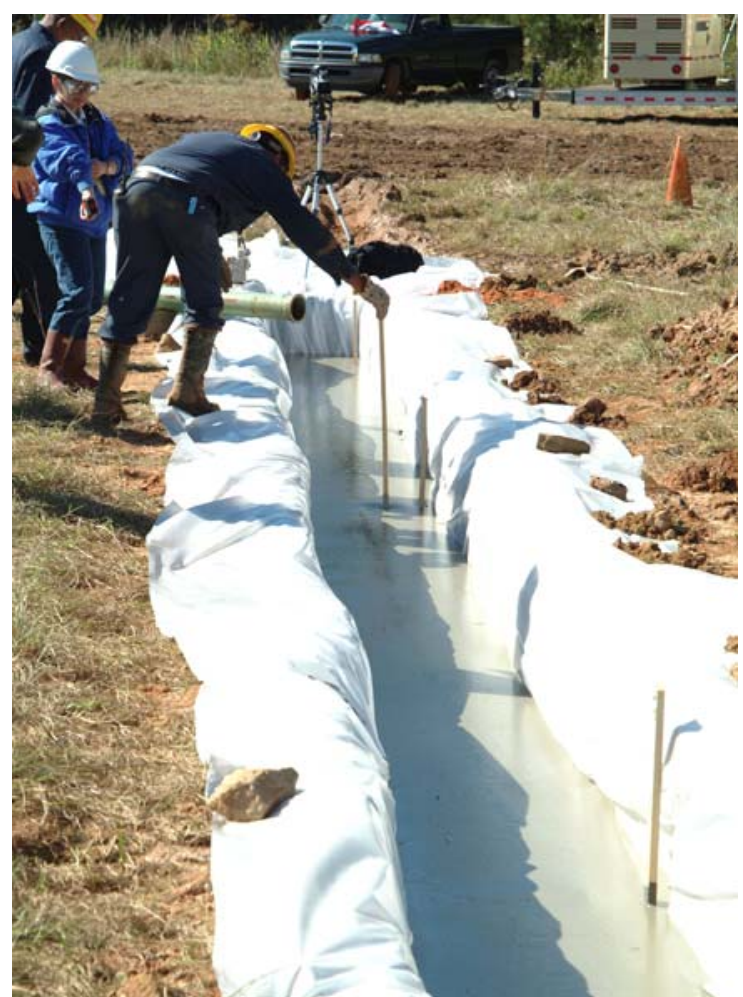

Figure 4-4. Structural grout in Trench 1 immediately after placement.

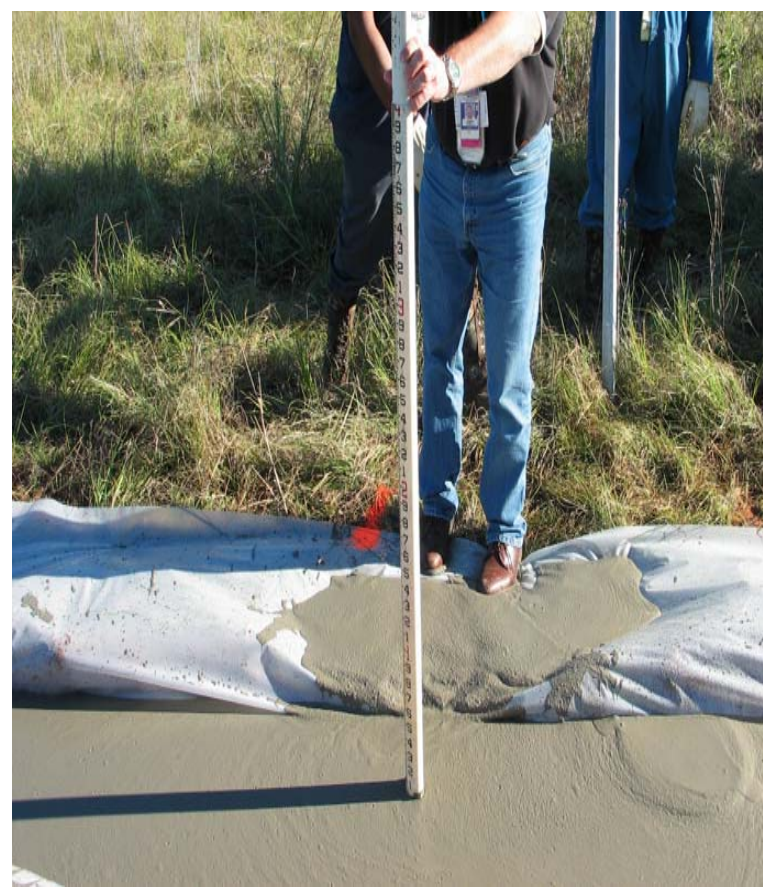

Figure 4-6. Capping grout in Trench 1 immediately after placement. 
WSRC-TR-2003-00556, Rev. 0

December 15, 2003

Page 33 of 55

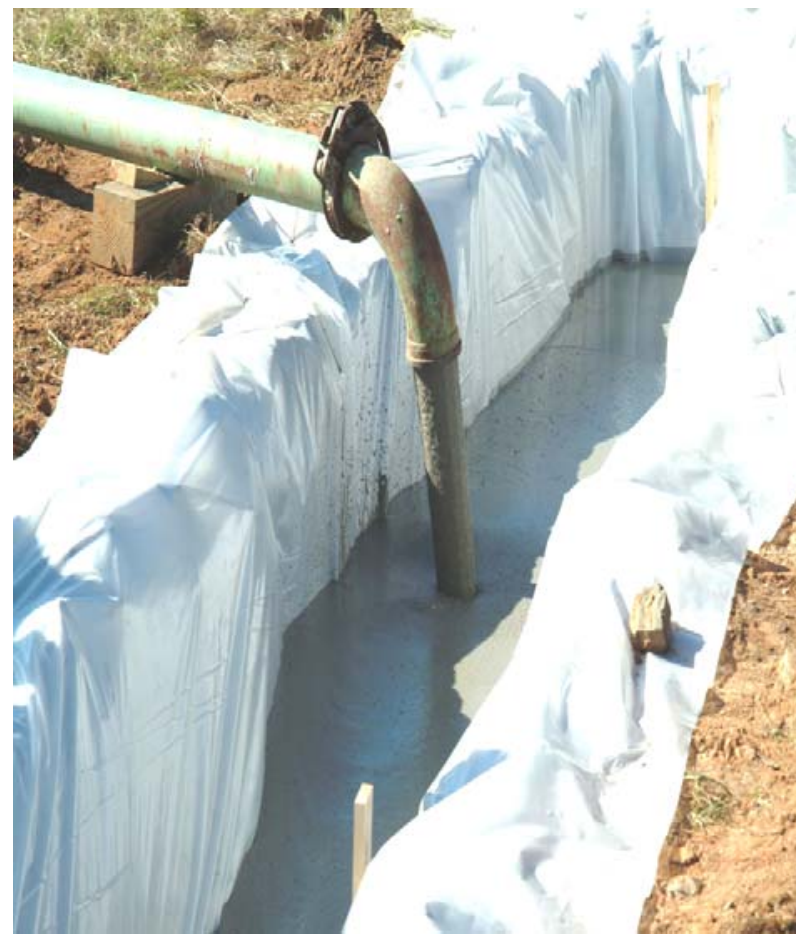

Figure 4-7. Stabilizing grout being placed in Trench 2 through a 5 inch slick line.

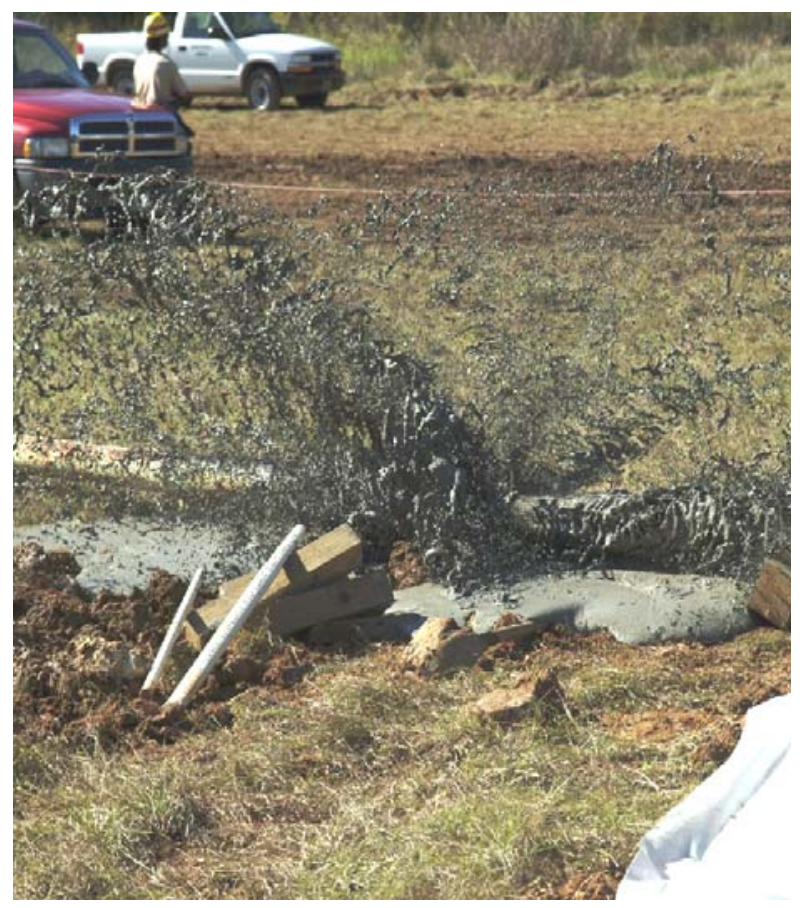

Figure 4-9. Slick line cleaning. Grout spray from pressurizing the line.

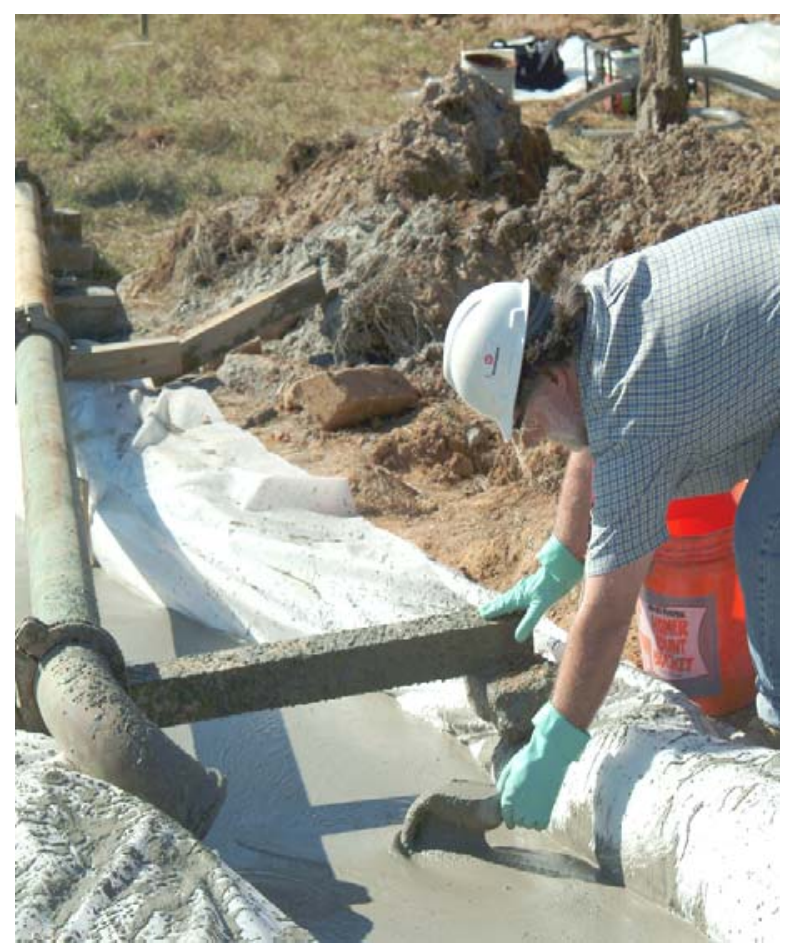

Figure 4-8. Capping grout in Trench 2 immediately after placement.

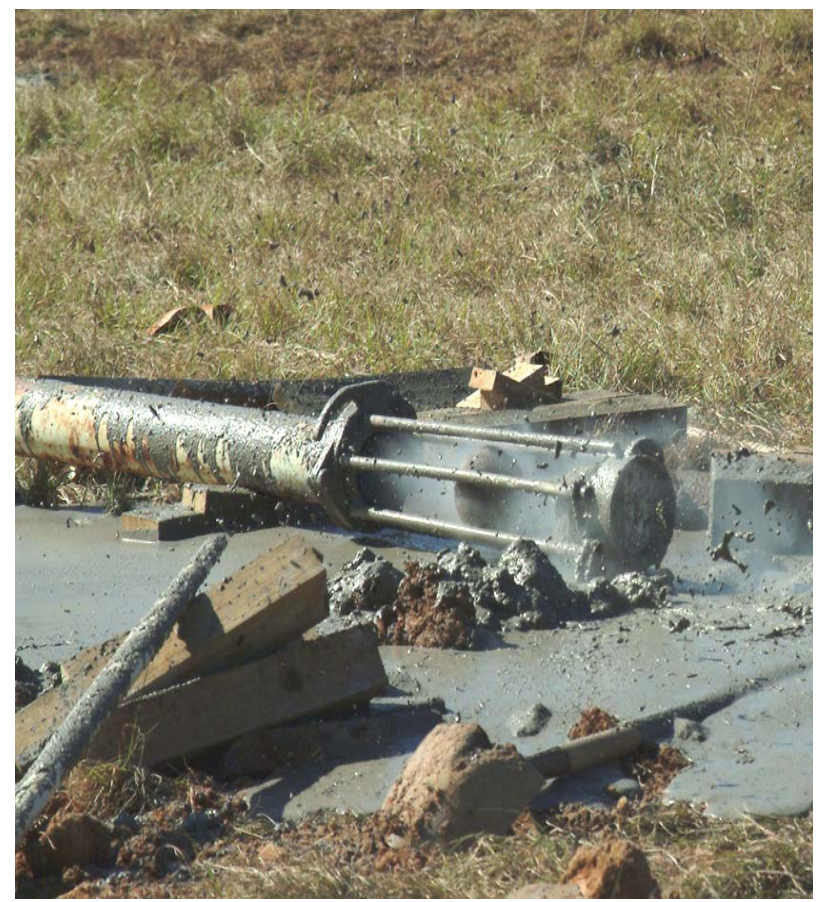

Figure 4-10. "Pig catcher" for catching the rubber ball used to clean the slick line. 


\subsection{Trench 3 Placements}

The effect of drop height on the grout properties was evaluated in Trench 3. The Capping grout, SRG9, was discharged from a height of 2 feet and also 10 feet. See Figures 4-11 and 4-12, respectively. The 2-foot drop was accomplished by attaching a tremie to the five-inch slick line. The tremie was used to prevent the flow stream from breaking up.

A minor amount of segregation, bleed water, was observed in both pours even though the grout flow measurements were within the target range for both pours. The amount of bleed water expressed in the pour dropped from two feet was very slight with standing water accumulating at the end of the trench. This indicates that the discharge end of the pour was higher than the far end. (Both pours were made from the end of an 80-foot long trench.) A flow of 13.5 inches per ASTM D6103 was measured for the HRG9 grout dropped through the tremie.

The amount of bleed water observed in Trench 3 after HRG9 was placed from a drop height of 10 feet was also minor and accumulated at the far end of the trench. A flow of 13.0 inches was measured for the grout dropped 10 feet. Bleed water was also measured on the samples of these HRG9 grouts collected for laboratory measurements as shown in Table 4-1.

A possible explanation for the minor amount of segregation in both mixes is that both batches of SRG9 contained the reference admixture dosage, 90 fluid ounces of ADVA Flow and 275 grams of Kelco-Crete per cubic yard. This proportioning was referred to as a 1:1 admixture dosage. Some of the other batches place during the field testing required additional admixture, which is a blend of a thickener (Kelco-Crete) and a dispersant (ADVA Flow). Many factors, including mixing time, hold time, mixing action, and admixture variability and timing of the additional water and admixtures probably contributed to the discrepancies.

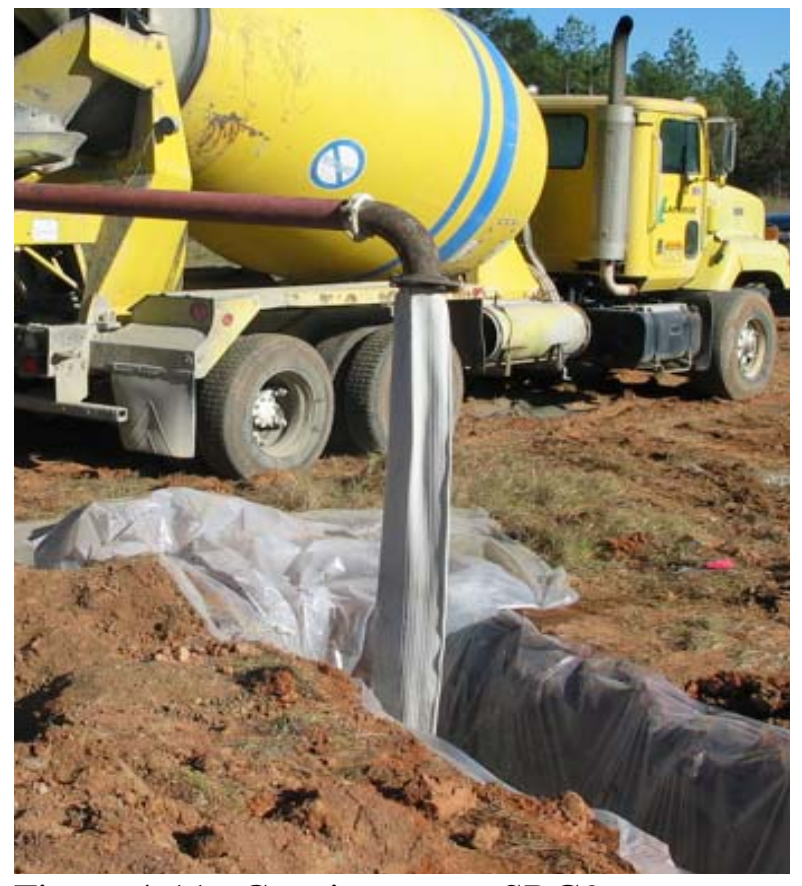

Figure 4-11. Capping grout, SRG9, discharged into Trench 3 from a two-foot drop through a tremie.

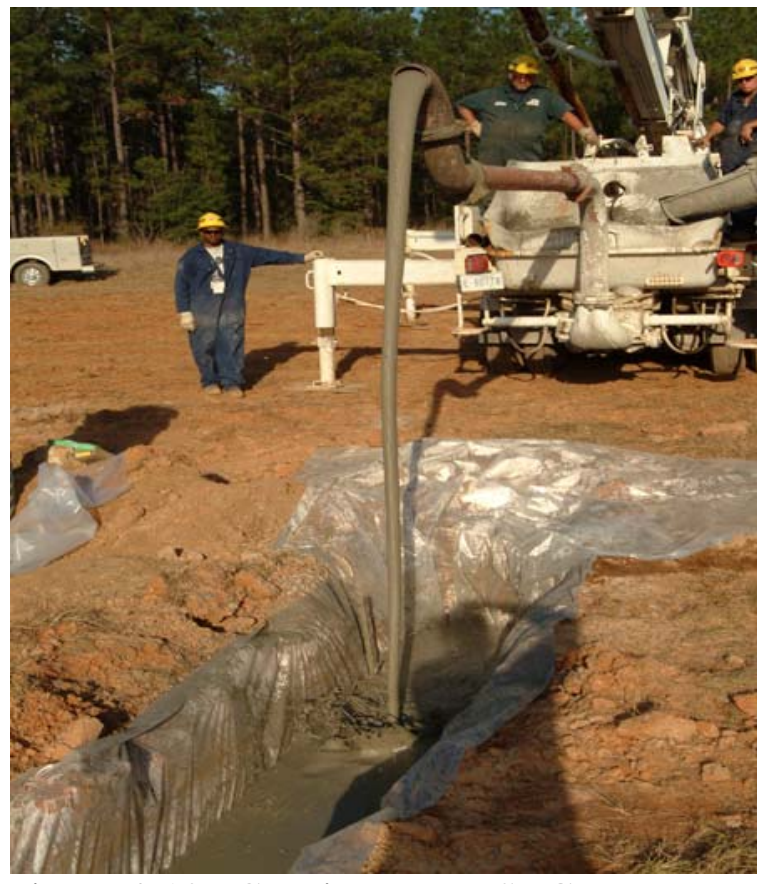

Figure 4-12. Capping grout, SRG9, discharged into Trench 3 from a ten-foot drop. 


\subsection{Culvert Placements}

Capping grout, HRG9 was placed in two ten-foot-long culverts set up in a vertical position to evaluate segregation as the result of a placement under head pressure. This test was intended to simulate the effect of filling the center dome of a high-level waste tank dome from a side riser 10 feet below the top of the dome. The grout was placed through a five-inch diameter line that was positioned about eight inches off the bottom of the culvert.

Culvert 1 was filled with HRG9 that had the reference (1X) admixture dosage (90 fluid ounces of ADVA Flow and 275 grams of Kelco-Crete per cubic yard). This mix had a slight amount of bleed water on the sample collected for property evaluation. This mix was also used in Trench 3 , where it was placed from a 2-foot drop height. In the trench, only a trace of bleed water was observed. However, in the culvert, about nine inches of standing water were observed. As illustrated in Figure 4-13, the top of the mix is very watery. The agitation caused by the mix and air entrapped by the pump action flowing through the already placed grout caused unacceptable segregation.

Culvert 2 was filled with the same grout formulation except that the admixture dosage was modified. The amounts of Kelco-Crete and ADVA Flow were both increased $50 \%$ to 412 grams and 136 fluid ounces per cubic yard, respectively. This mix was very cohesive and resulted in a flow test value of only 11 inches which is less than the design value of 13.5 inches. This mix filled the culvert and was suitable for placement under head pressure. Rather than allowing air introduced by the pump action to bubble out of the grout, this mix was cohesive enough to trap the air. See Figure 4-14. The surface of this grout placement was lifted as the culvert was filled. The difference in the two Culvert tests is clearly illustrated in Figures 4-13 and 4-14.

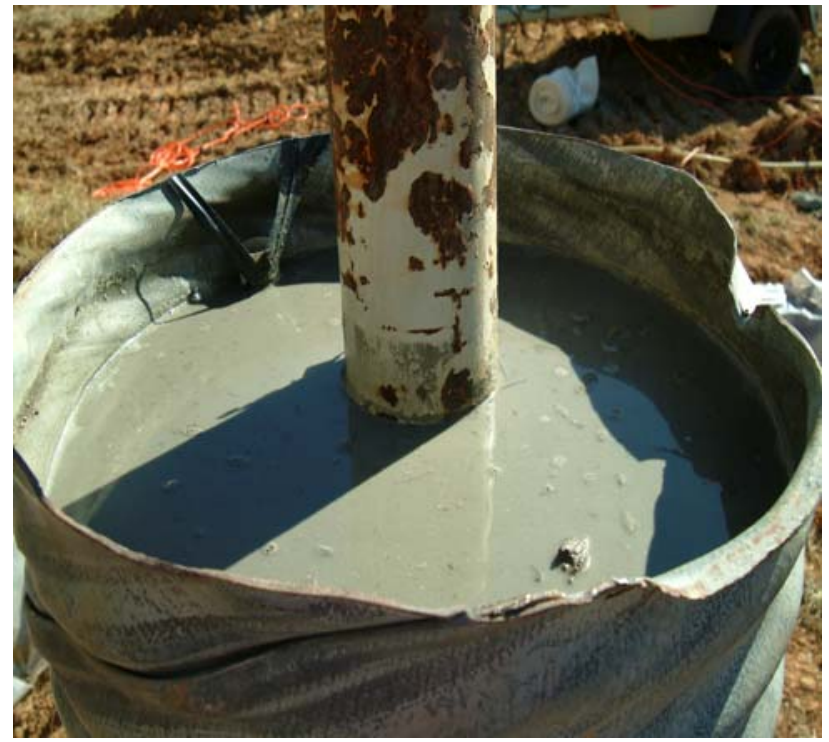

Figure 4-13. Capping grout placement in Culvert 1.

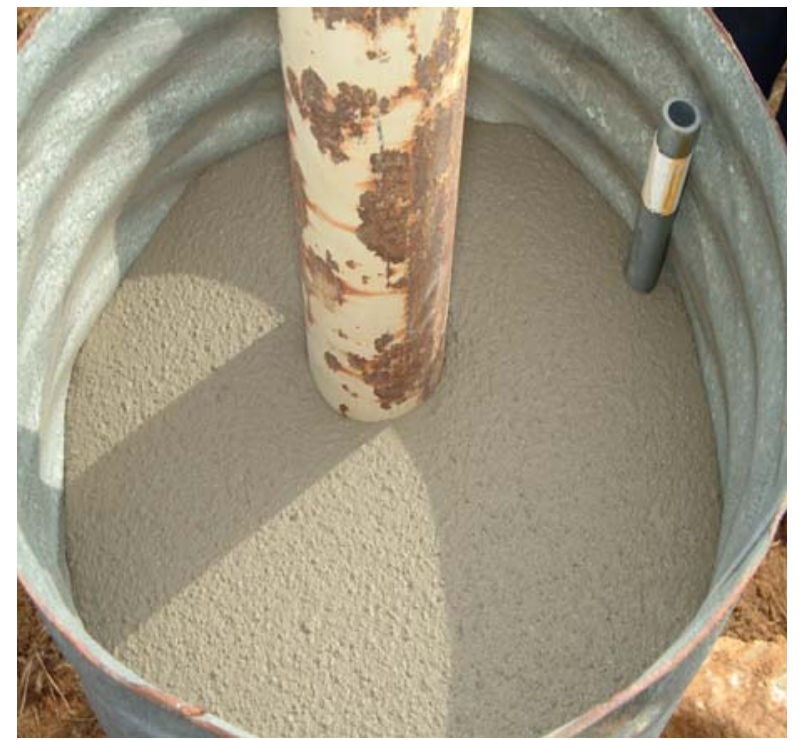

Figure 4-14. Capping grout placement in Culvert 2. 


\subsection{Swimming Pool 1}

Swimming pool 1 contained Tank C-106 simulant and miscellaneous simulated debris as illustrated in Figure 4-15. The first pour, the Stabilization grout, SRG4 was placed in direct contact with the simulants, Figure 4-16. Due to problems with the seals on the pump truck, only about one cubic yard was placed in the first layer. This was enough to cover the solid fraction of the simulated heel (clay, sand, and gravel) and some of the small metal debris.

Approximately 1500 pounds (thirty 50-pound bags) of top dressing were applied to the displaced supernate fraction of the heel. A pre-blended mixture of Type I/II portland cement, Grade 100 blast furnace slag, and Class F fly ash was used as the top dressing. The top dressing was pneumatically applied through a central opening in the top of the plastic hut. The hut contained most of the top dressing and the dust settled within 12 hours. The specific gravities of the cement, slag, and fly ash particles were 3.1, 2.9, and 2.4, respectively. The particles in the top dressing also coated the side-walls of the pool form as illustrated in Figures 4-18 and 4-19.

A second layer of Stabilizing grout (about 7 cubic yards) was placed over the first top dress layer. See Figure 4-17. The grout flowed evenly over the top dressing, most of which had been wetted by the supernate and fixed to the first stabilization layer. The second layer of Stabilizing grout covered all of the debris. Immediately after the second stabilization pour, an additional 1500 pounds (about 30 bags) of top dressing were applied to solidify the remaining supernate. Most of the supernate was fixed in place after the second top dress application. The small amount left around the edges of the form was incorporated into the subsequent Structural grout layer. The second top dressed layer is the dark gray layer near the bottom of the pour in Figure 4-20. The dark gray color indicates the presence of ferric iron phases that are responsible for the chemical reduction associated with the stabilizing chemistry. Unreacted top dressing is shown as the light gray material on the sides and top surface of the monolith. The sides were coated during the top dressing application. The top was coated as the result during dismantling the hut.

Seven cubic yards of the Structural grout was placed over the second top dressing. See Figure 4-18. Approximately 7 cubic yards of the Capping grout were placed on top of the Structural grout. See Figure 4-19. The form for the Swimming Pool 1 was stripped 5 days after the final Capping grout pour. The resulting monolith is shown in Figure 4-20.

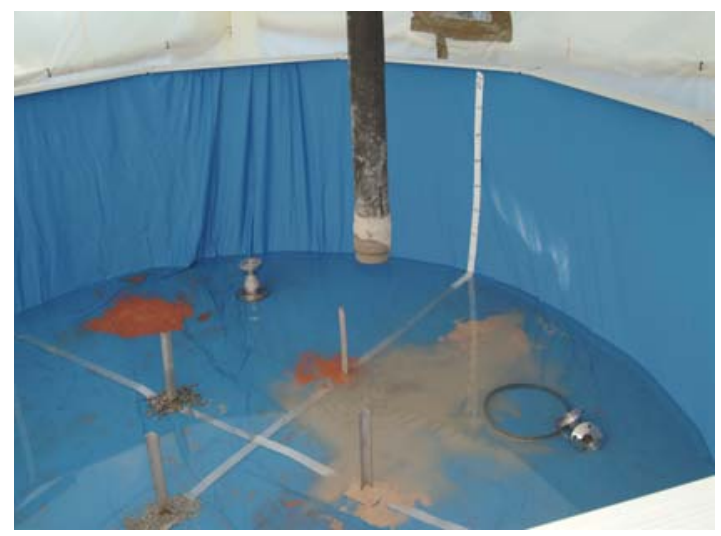

Figure 4-15. Stabilizing grout and C-106 simulated heel and debris, Pool 1.

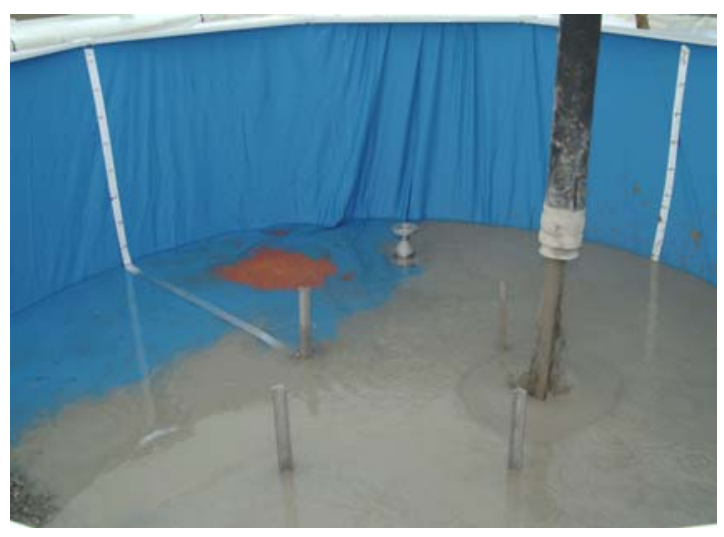

Figure 4-16. Stabilization grout as covering solid simulated heel and displacing supernate portion of the simulated heel. 
WSRC-TR-2003-00556, Rev. 0

December 15, 2003

Page 37 of 55

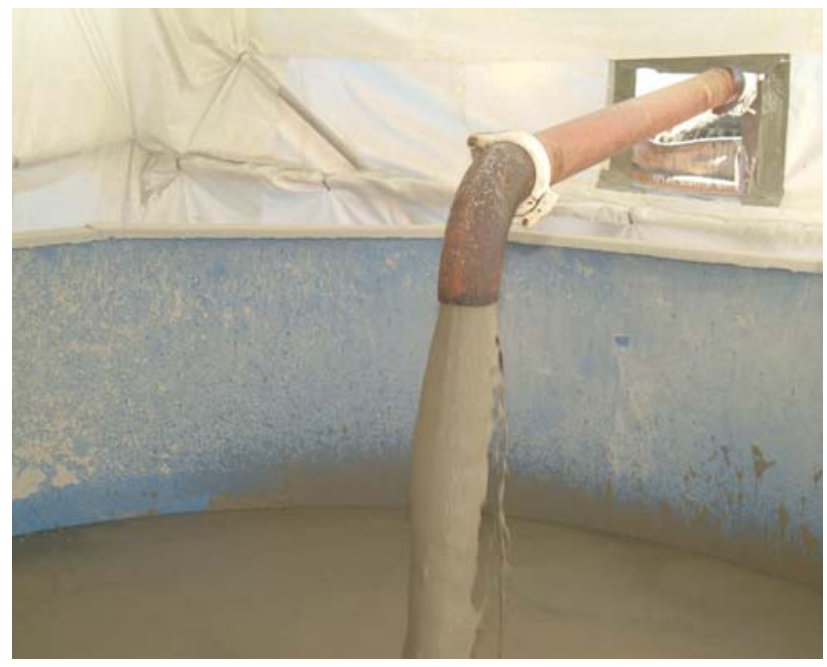

Figure 4-17. Stabilizing Grout (layer 2) placed on dry grout and C-106 simulanted heel.

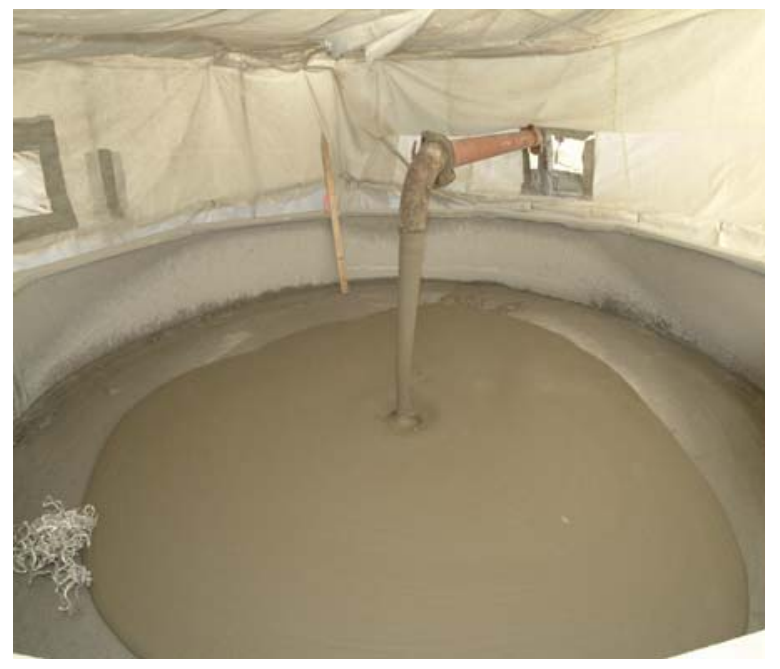

Figure 4-19. Capping grout in Pool 1.

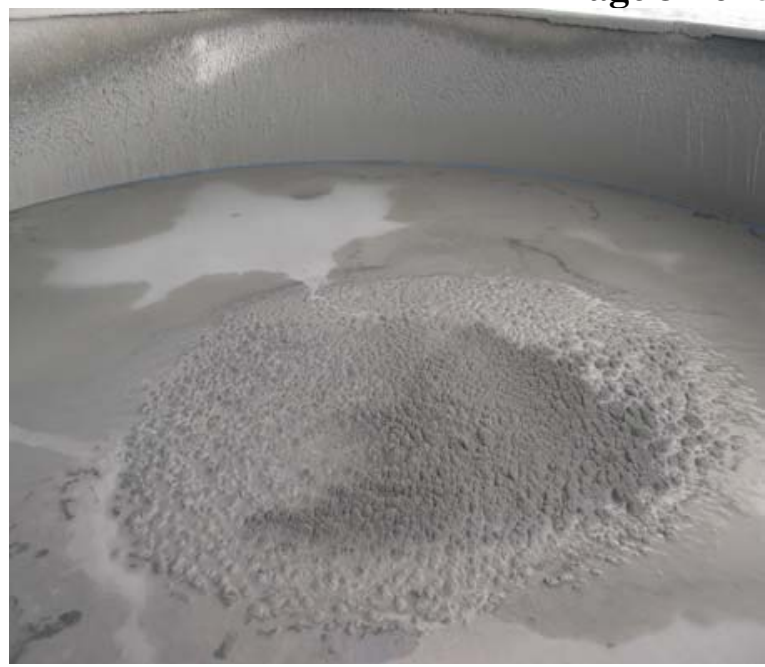

Figure 4-18. Top dressing over the second Stabilization Grout layer.

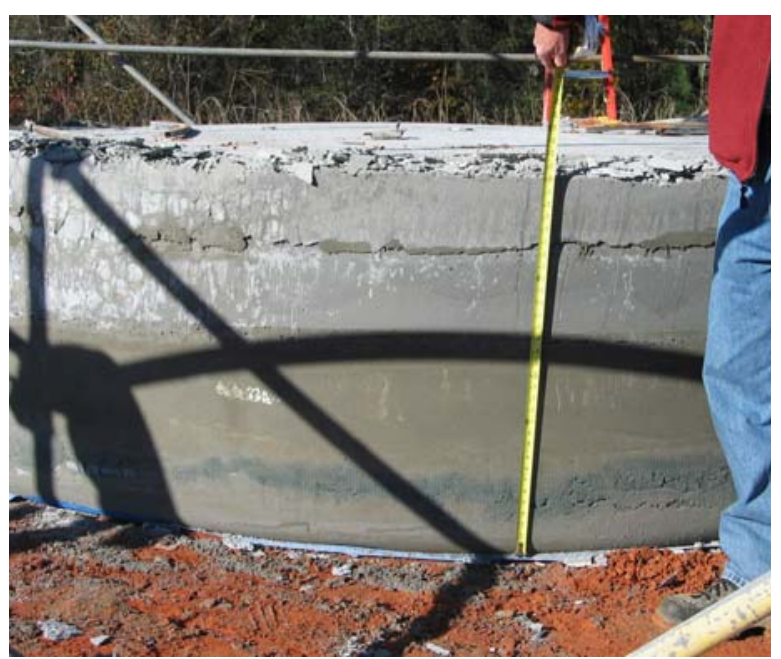

Figure 4-20. Pool 1 with form removed.

\subsection{Swimming Pool 2}

Swimming pool 2 contained Tank C-200 series average simulant and miscellaneous simulated debris as illustrated in Figure 3-12. Aluminum hydroxide (white precipitate) was used to simulate unconsolidated sludge particles. The liquid portion of the heel was a concentrated sodium nitrate, sodium hydroxide solution. The first pour, about 5 cubic yards of the Stabilization grout, SRG4, was placed in direct contact with the caustic simulant. The grout covered the simulated sludge and flowed in and around the soil, sand, gravel, and debris. The supernate was displaced by the grout and formed a ring around the edge of the pool. See Figures 4-21 and 4-22. The Stabilizing grout flow was essentially the same for Pools 1 and 2. No adverse reactions were observed in the Stabilization grout as the result of contact with the concentrated caustic salt supernate. 
Swimming Pool 2 was covered with a plastic sheet between pours to prevent evaporation of the simulated heel supernate that was displaced by the Structural grout. About seven cubic yards of the Structural grout were placed over the Stabilization grout. Some of the simulated supernate heel was incorporated in the Stabilization grout. The remainder was displaced by the Structural grout and accumulated around the edge of the pool as shown in Figure 4-22.

About 3.5 cubic yards of the Capping grout, SRG9, were placed on the Stabilization grout. See Figure 4-23. A small amount of supernate was also present at the beginning of the Capping grout pour. However, all of the simulated heel supernate was incorporated into the Capping grout by the end of the pour. No bleed water or segregation occurred as the Capping grout cured. The form for the Swimming Pool 2 was stripped 5 days after the final Capping grout pour. The resulting three pour monolith is shown in Figure 4-24.

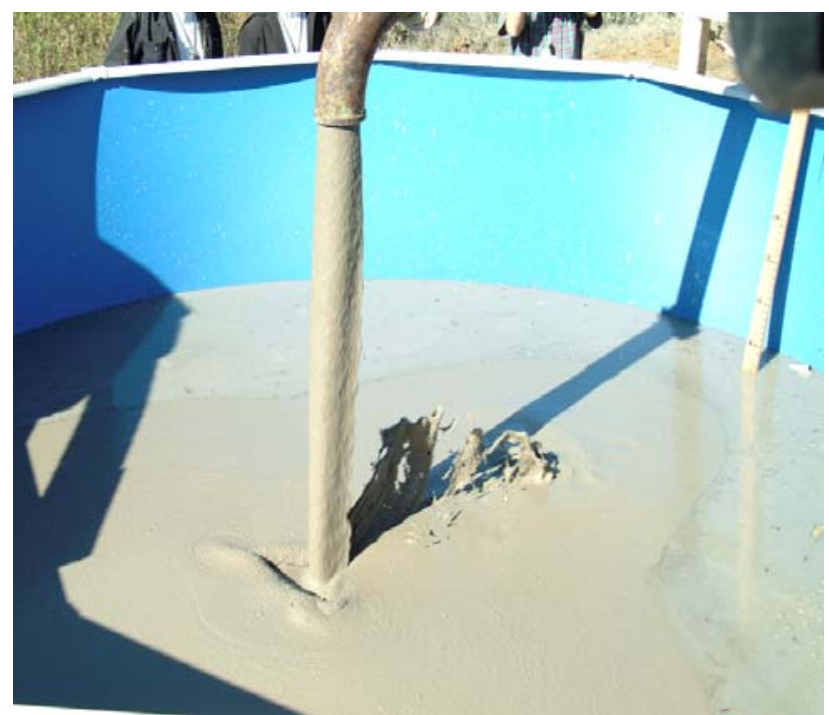

Figure 4-21. Stabilizing grout - Pool 2.

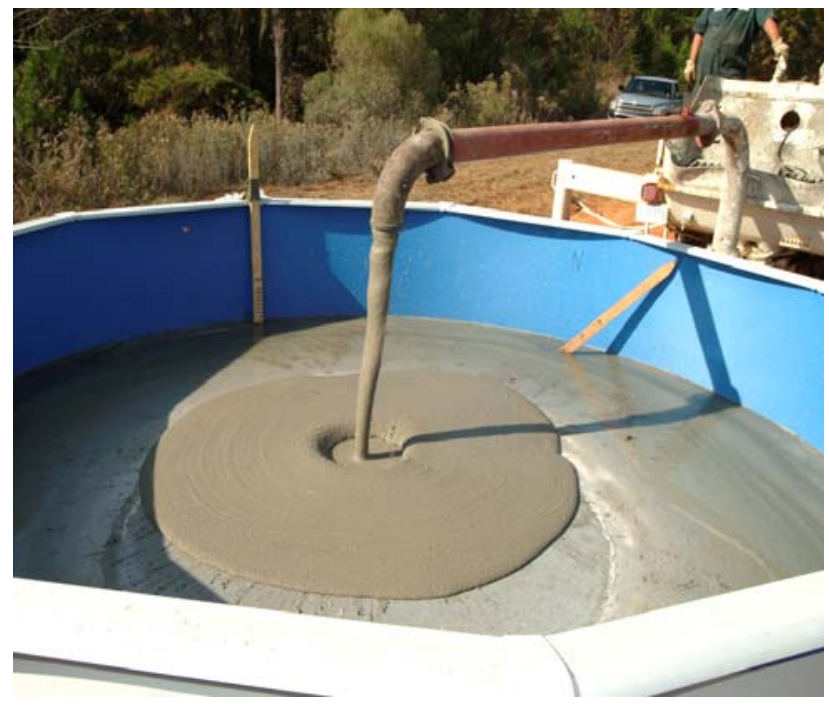

Figure 4-23. Capping grout - Pool 2.

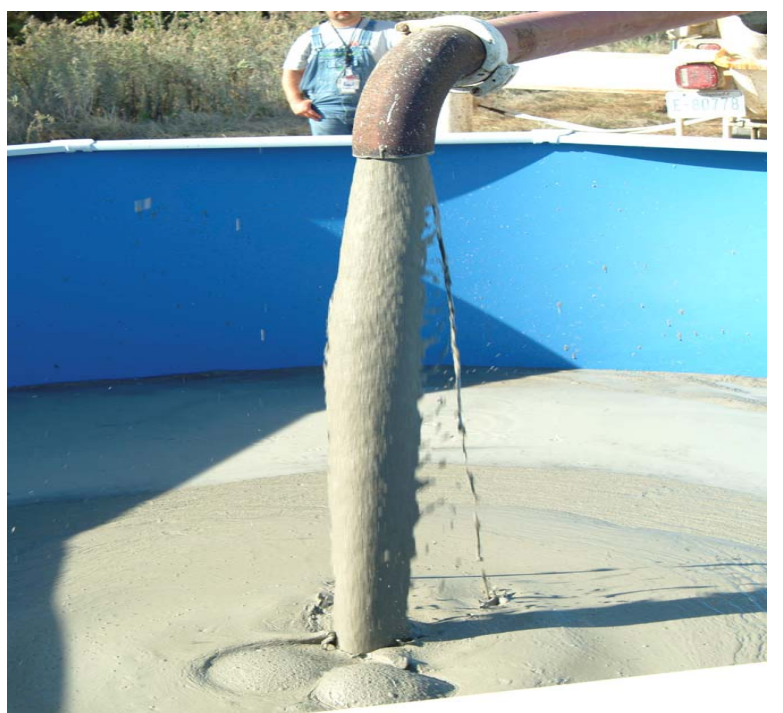

Figure 4-22. Structural grout - Pool 2.

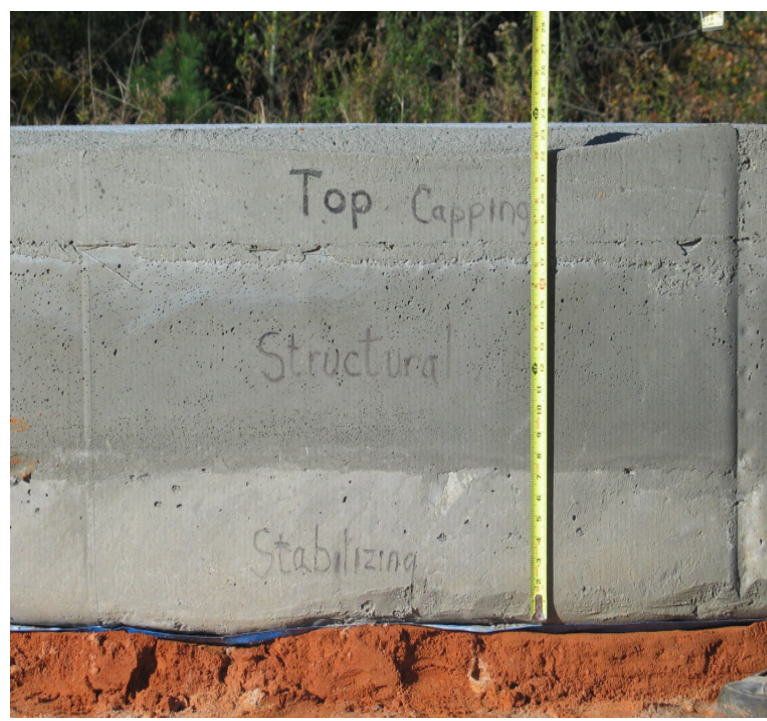

Figure 4-24. Pool 2 after the form was removed, 5 days after final pour. 


\subsection{Grout-Heel-Debris Interaction}

Page 39 of 55

The supernate portion of the simulated heels in Pools 1 and 2 was displaced upwards by the Stabilization grout. In Pool 1, dry grout top dressing was used to immobilize the C-106 simulated supernate liquid. The dry grout layer (second application) is shown in Figure 4-25 sandwiched between the second Stabilization grout layer and the Structural grout layer. The supernate portion of the C-200 series heel in Pool 2 was incorporated into the Stabilization and Structural grout layers by sorption and/or mixing.

The $\mathrm{C}-200$ series simulant included aluminum hydroxide to simulate the sludge portion of the heel. In the center of the pool form where the grout was discharged, the simulated solid sludge was mixed with the grout as illustrated in Figure 4-26 (rough surface) or was covered by and cemented to the Stabilization grout (top right corner of Figure 4-26).

All of the simulated debris was completely filled and covered by the Stabilization grout. See Figures 4-27 and 4-28.

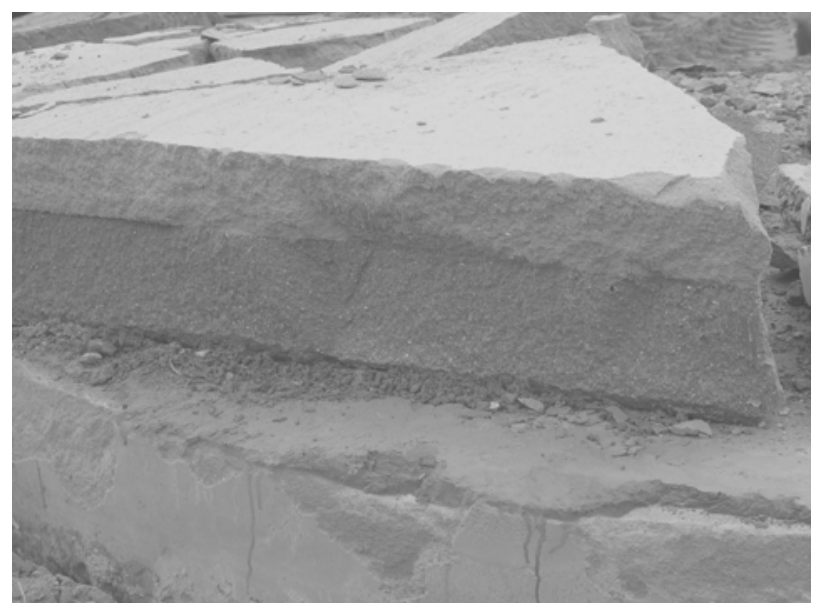

Figure 4-25. Pool 1, $2^{\text {nd }}$ top dressing, thin dark gray layer, between the top of the $2^{\text {nd }}$ Stabilization grout and Structural grout.

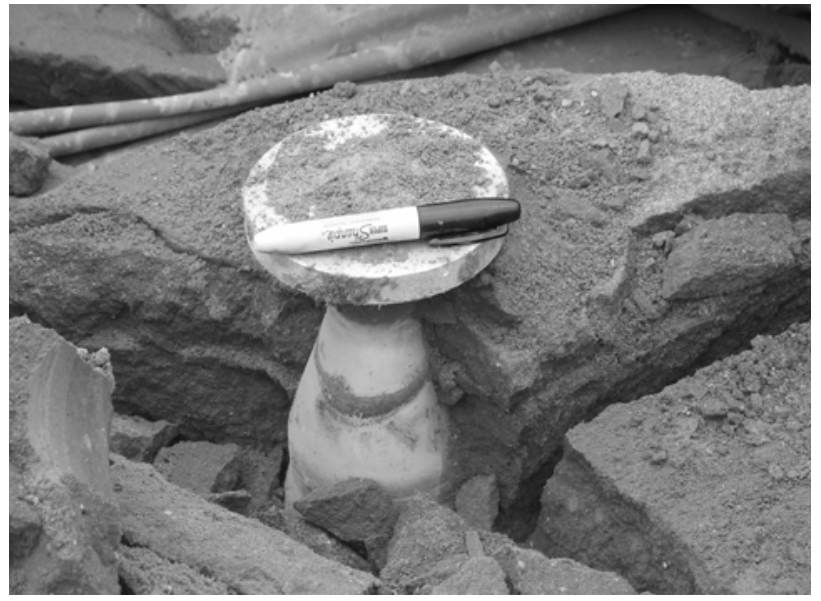

Figure 4-27. Simulated debris in Pool 1 filled and covered with Stabilization grout. (Marker for reference.)

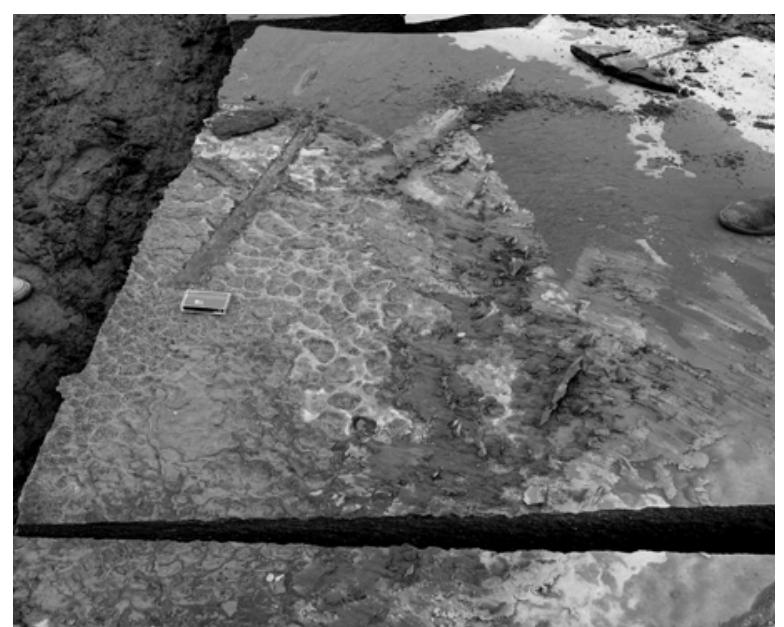

Figure 4-26. Debris in Pool 2 filled with Stabilization grout (bottom-side).

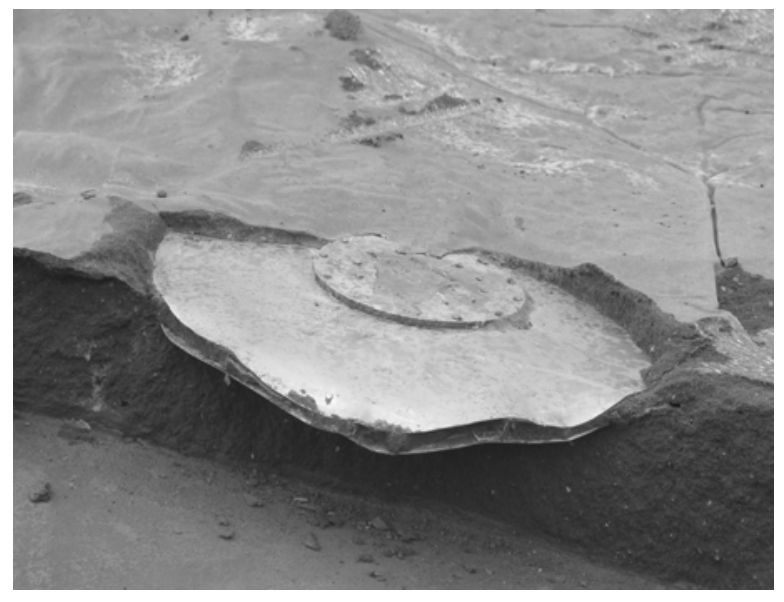

Figure 4-28. Simulated debris in Pool 2 filled and covered with Stabilization grout. 


\subsection{Equipment and Riser Grout}

Page 40 of 55

Four to four and one half gallons of each of the three cable grouts were prepared for the pipe filling tests. The amounts of water in the grouts (per manufactures instructions) and the resulting flows per ASTM C-939 are listed in Table 4-6. Cross-sections through the various one-inch pipes are shown in Figures 4-29 to 4-34. Samples of the grout were not collected for cured property measurements.

Table 4-6. Cable grout mix proportions and properties.

\begin{tabular}{|c|c|c|c|c|c|c|}
\hline $\begin{array}{l}\text { Test } \\
\text { No. }\end{array}$ & $\begin{array}{c}\text { Test } \\
\text { Description }\end{array}$ & Grout & $\begin{array}{c}\text { Grout } \\
\text { (amount) }\end{array}$ & $\begin{array}{l}\text { Water } \\
\text { (lbs) }\end{array}$ & $\begin{array}{l}\text { Flow ASTM } \\
\text { C-939 (sec.) }\end{array}$ & Observations \\
\hline 1 & $\begin{array}{l}\text { Vertical } 20 \mathrm{ft} \\
\text { length of 1-inch } \\
\text { PVC pipe, } \\
\text { Filled from top, } \\
\text { Gravity Pour }\end{array}$ & 816 & $1 \mathrm{bag}$ & 25 & 22 & $\begin{array}{l}\text { One-inch PVC pipe } \\
\text { filled easily using } \\
\text { the funnel from the } \\
\text { pump hopper to aid } \\
\text { delivery into pipe. } \\
\text { Fill time est. } 1 \text { min. }\end{array}$ \\
\hline 2 & $\begin{array}{l}\text { Vertical } 20 \mathrm{ft} \\
\text { length of 1-inch } \\
\text { PVC pipe, } \\
\text { Filled from top, } \\
\text { Pumped through } \\
3.8 \text { inch tubing } \\
\text { from bottom up }\end{array}$ & \multicolumn{4}{|c|}{ Same batch as above. } & Fill time $<1 \mathrm{~min}$. \\
\hline 3 & $\begin{array}{l}\text { Vertical } 20 \mathrm{ft} \\
\text { length of } 1 \text {-inch } \\
\text { PVC pipe w/ } \\
\text { three wires } \\
\text { Filled from top, } \\
\text { Pumped through } \\
3.8 \text { inch tubing } \\
\text { from bottom up }\end{array}$ & 1205 & 1 bag & 20 & 15.5 & Fill time $<1$ min. \\
\hline 4 & $\begin{array}{l}\text { Vertical } 20 \mathrm{ft} \\
\text { length of 1-inch } \\
\text { PVC pipe, } \\
\text { Filled from top, } \\
\text { Pumped through } \\
3.8 \text { inch tubing } \\
\text { from bottom up }\end{array}$ & 1341 & 1 bag & 27 & 21 & $\begin{array}{l}\text { Grout generated } \\
\text { heat during mixing. } \\
\text { Fill time }<1 \text { min. }\end{array}$ \\
\hline 5 & $\begin{array}{l}\text { W-shaped } \\
\text { configuration } 60 \\
\mathrm{ft} \text { long, } \\
\text { 1-inch PVC pipe, } \\
\text { Filled from top, } \\
\text { Pumped through } \\
3.8 \text { inch tubing } \\
\text { from bottom up }\end{array}$ & 1205 & 1 bag & 19 & 19 & $\begin{array}{l}\text { Air blocks } \\
\text { prevented complete } \\
\text { filling. Pipe was } \\
\text { punctured in } 2 \\
\text { locations to release } \\
\text { air. Filling was } \\
\text { completed in }<4 \\
\text { min. }\end{array}$ \\
\hline
\end{tabular}




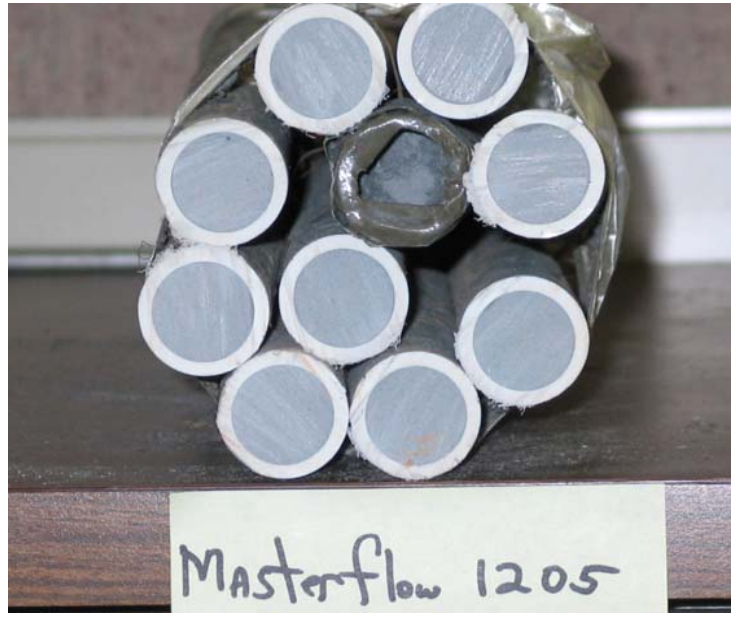

Figure 4-29. Sections of a one-inch PVC pipe $(20 \mathrm{ft}$ long) filled from the top with Masterflow 1205 grout.

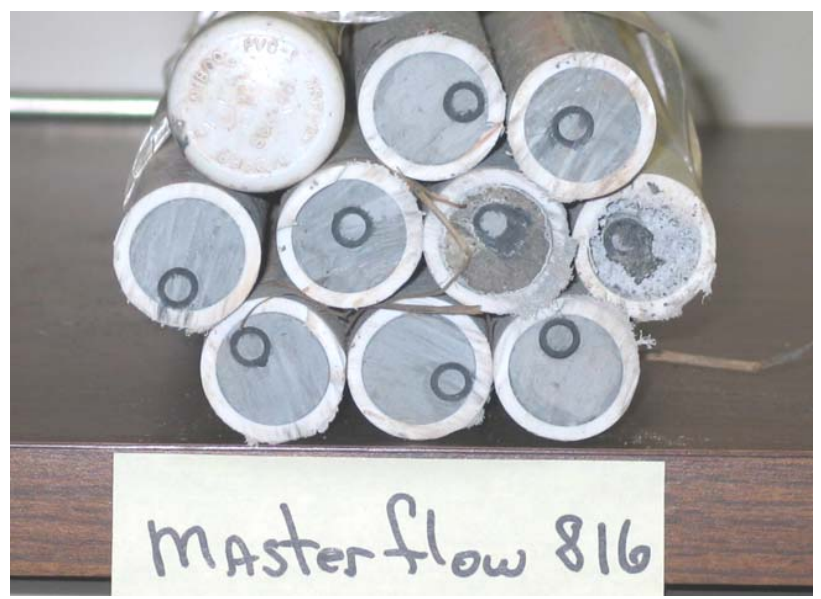

Figure 4-31. One-inch PVC pipe (20 foot section) filled with Masterflow 816 grout pumped through a $3 / 8$ inch tube.

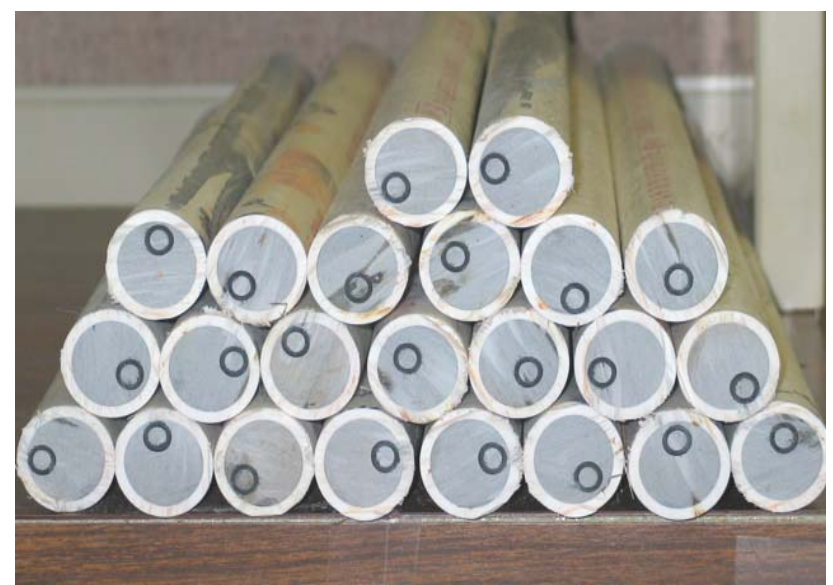

Figure 4-33. One-inch PVC pipe (60 feet long) filled with Masterflow 1205 grout.

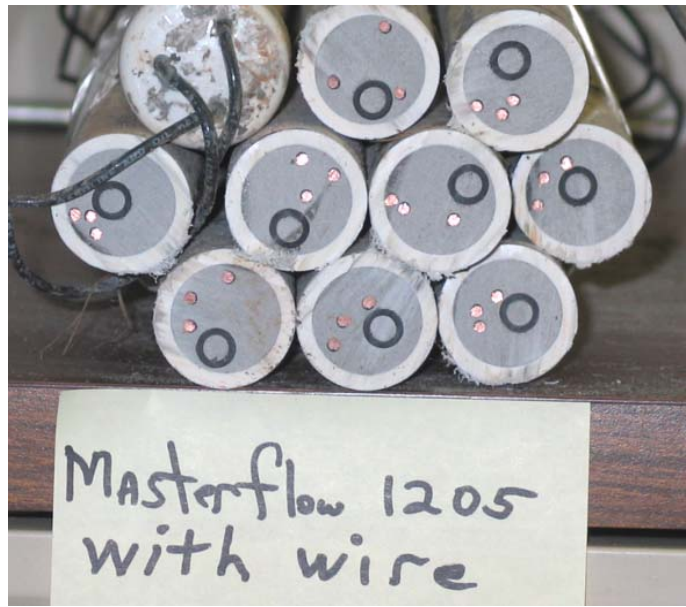

Figure 4-30. One-inch PVC pipe with copper wires filled with Masterflow 1205 grout pumped through $3 / 8$ inch tube.

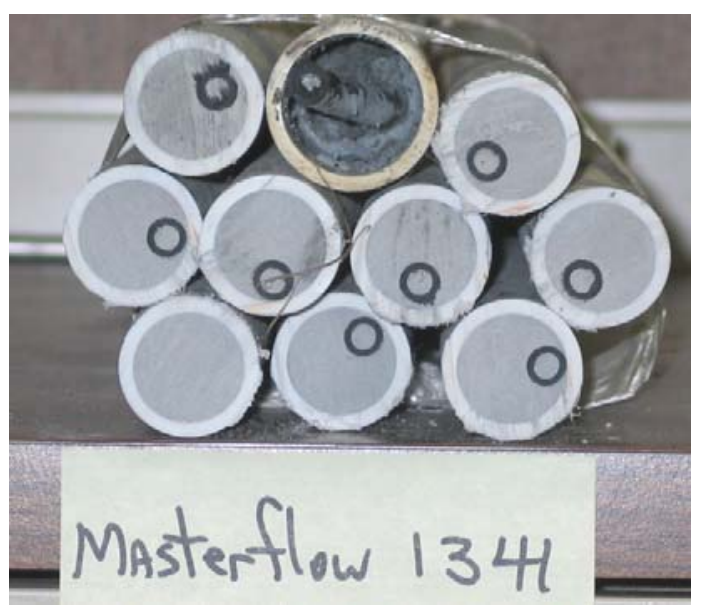

Figure 4-32. One-inch PVC pipe (20 foot section) filled with Masterflow1341 grout pumped through a $3 / 8$ inch tube.

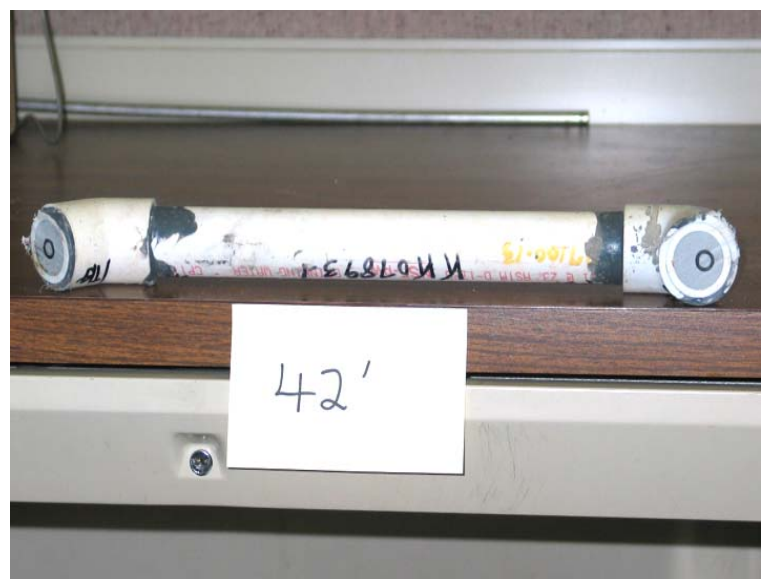

Figure 4-34. Section of 60-foot PVC pipe filled with masterflow 1205 gout. 


\subsection{DISCUSSION}

\subsection{Variability in Grout Composition}

Variability in the tank closure grout compositions was evaluated. The results were within batching tolerances per ACI 304R Manual of Concrete Practice. See Table 5-1.

The percent differences between actual and targeted values for these three components are within the acceptance criterion of $\pm 1 \%$ except for one mix with the lowest amount of portland cement (SRG2). For the Structural grout, SRG2, the difference between the targeted value of $75 \mathrm{lbs} / \mathrm{cyd}$ and the actual value of $76 \mathrm{lbs} / \mathrm{cyd}$ is only one pound. Since the sensitivity of the measurement is \pm 1 pound, a variance of $1.1 \mathrm{wt}$. \% was calculated which is slightly greater than the $\pm 1 \mathrm{wt} . \%$ acceptance criterion. Per ACI, a variance of $\pm 2 \mathrm{wt} . \%$ is allowed for binder ingredients that are added in amounts of less than $100 \mathrm{lbs} / \mathrm{cyd}$.

The variability in the amount of sand (the major component of the grout with about 10 times more mass than any other component) was also evaluated. The percent differences between the actual and targeted values for the sand in each of the 15 mixes were less than or equal to the acceptance criterion of \pm 2 wt. $\%$.

Table 5-1. Variation in actual versus design weights for ingredients in 15 grout batches.

\begin{tabular}{|l|c|c|c|}
\hline \multirow{2}{*}{ Component } & \multicolumn{3}{|c|}{ Range of Variability (\%) } \\
\cline { 2 - 4 } & Minus & Plus & ACI 304R \\
\hline Portland Cement* & -0.9 & 1.1 & \pm 1.0 \\
\hline Blast Furnace Slag & -0.8 & 0.7 & \pm 1.0 \\
\hline Fly Ash & -1.0 & 0.6 & \pm 1.0 \\
\hline Sand & -2.0 & 0.9 & \pm 2.0 \\
\hline
\end{tabular}

$* \pm 2.0 \%$ is acceptable for ingredients added in amounts of less than $100 \mathrm{lbs} / \mathrm{cyd}$ as was the case for SRG2.

The amounts of free water in the sand is another compositional variable that affects the weight of the sand and amount of mixing water. The free water in the sand is measured at the batch plant at the beginning of each day. For the 15 mixes produced during the scale-up testing, the water content of the sand varied between 3.4 and $5.0 \mathrm{wt} \%$. The free moisture in the sand invariably changed throughout the day and introduced a source of undocumented error to the total water contents of the mixes produced in the scale-up testing.

The amount of water and admixture added to each mix upon delivery at the Burma Road Site were recorded and added to the amount included at the batch plant. These water and admixture additions were based on achieving the desired flow and cohesiveness. All of the mixes that had the design amount of admixture required less water than specified in the design. The average percent variability in water content versus the targeted design value was $-9.1 \%$. One explanation for this difference is that some wash water was retained in the truck and/or central mixer and was incorporated in the test mixes. Another explanation is that, under the conditions of the field testing, less water is required to obtain the desired flow property. 
For mixes that contained 1.5 times the amount of admixture (except for the batch in Truck 15 which was purposely formulated with a low flow of 11 inches), the amount of water required was always greater than the targeted amount. On average these high admixture batches required $4.75 \%$ more water than the design value. The reason for this is most likely that the extra KelcoCrete (thickener component of the admixture) requires extra water in the grout to obtain equivalent flow with the mix.

These results demonstrate the importance of providing the capability to adjust the water and admixture dosages in the tank fill grouts based on observations from of the actual flow during full-scale placement. It is also important to correlate these observations and mix adjustments with the ASTM D-6103 flow measurements.

Remote batching at a plant that makes several different mixes for different customers each day can introduce additional compositional variability. For example, in one of the mixes used during the scale-up testing, a small amount of coarse granite aggregate was present in the grout because the plant batched a concrete mix for another customer.

\subsection{Comparison of Bench-Scale and Field Grout Properties}

The mix designs developed in the bench-scale studies met the fresh and cured properties requirements provided by CH2M HILL $[5,9]$. A comparison of the Structural Grout properties for mixes prepared in the laboratory using Hanford materials (HRG2 Bench) and Savannah River materials (SRG2 Bench) and mixes batched for the scale-up testing (SRG2 Truck prepared from Savannah River materials) is provided in Table 5-2. All three HRG mixes should be batched using materials available at the Hanford site at a field scale (8 to 10 cubic yards) to identify the maximum water and admixture levels that can be used and still meet the placement requirements.

Table 5-2. Physical Properties of the Structural Grouts (HRG2 and SRG2) Prepared in the Bench-Scale [9] and Scale-Up Tests.

\begin{tabular}{|l||c||c||c|c|c|c|}
\hline Property & $\begin{array}{l}\text { HRG2 } \\
\text { Bench }\end{array}$ & $\begin{array}{l}\text { SRG2 } \\
\text { Bench }\end{array}$ & $\begin{array}{l}\text { SRG2 } \\
\text { Truck 2 }\end{array}$ & $\begin{array}{l}\text { SRG2 } \\
\text { Truck 5 }\end{array}$ & $\begin{array}{l}\text { SRG2 } \\
\text { Truck 10 }\end{array}$ & $\begin{array}{l}\text { SRG2 } \\
\text { Truck 11 }\end{array}$ \\
\hline Admixture Dosage* & $1 \mathrm{X}$ & $1 \mathrm{X}$ & $1.5 \mathrm{X}$ & $1.5 \mathrm{X}$ & $1.2 \mathrm{X}$ & $1.2 \mathrm{X}$ \\
\hline Flow (inches) & 15 & 13.5 & 13.75 & 13.75 & 13.00 & 13.00 \\
\hline \multicolumn{1}{|l||}{ Bleed Water (mL after 24 hr) } & none & none & none & none & none & none \\
\hline Compressive Strength (psi) & & & & & & \\
\hline \multicolumn{1}{|c||}{14 days } & 535 & 765 & 815 & 865 & 1030 & 750 \\
\hline 28 days & 825 & 1400 & 1700 & 1750 & 1500 & 1750 \\
\hline 90 days & 1275 & 1935 & 2720 & 2650 & 2650 & 2500 \\
\hline Young's Modulus (psi) & $2.3 \mathrm{E}+05$ & -- & $3.2 \mathrm{E}+05$ & $3.2 \mathrm{E}+05$ & $3.8 \mathrm{E}+05$ & $3.0 \mathrm{E}+05$ \\
\hline Poisson's Ratio & & & 0.33 & 0.17 & 0.14 & 0.17 \\
\hline $\begin{array}{l}\text { Saturated Hydraulic } \\
\text { Conductivity (cm/sec) }\end{array}$ & $2.5 \mathrm{E}-07$ & & & $7.1 \mathrm{E}-08$ & & \\
\hline
\end{tabular}

* The amount of the admixture blend relative to the reference blend is indicated as a factor relative to the reference amount. The reference blend contained 90 fluid ounces of ADVA Flow and 275 grams of Kelco-Crete. 
A comparison of the Stabilizing Grout properties for mixes prepared in the laboratory using Hanford materials (HRG4 Bench) and Savannah River materials (SRG4 Bench) and mixes batched for the scale-up testing (SRG4 Truck prepared from Savannah River materials) is provided in Table 5-3. A comparison of the Capping Grout properties for mixes prepared in the laboratory using Hanford materials (HRG9 Bench) and Savannah River materials (SRG9 Bench) and mixes batched for the scale-up testing (SRG9 Truck, prepared from Savannah River materials) is provided in Table 5-4.

Table 5-3. Physical Properties of the Stabilization Grouts (HRG4 and SRG4) Prepared in the Bench-Scale [9] and Scale-Up Tests.

\begin{tabular}{|l||c||c||c|c|c|c|c|}
\hline Property & $\begin{array}{c}\text { HRG4 } \\
\text { Bench }\end{array}$ & $\begin{array}{c}\text { SRG4 } \\
\text { Bench }\end{array}$ & $\begin{array}{c}\text { SRG4 } \\
\text { Truck 1 }\end{array}$ & $\begin{array}{c}\text { SRG4 } \\
\text { Truck 4 }\end{array}$ & $\begin{array}{c}\text { SRG4 } \\
\text { Truck 7 }\end{array}$ & $\begin{array}{c}\text { SRG4 } \\
\text { Truck 8 }\end{array}$ & $\begin{array}{c}\text { SRG4 } \\
\text { Truck 9 }\end{array}$ \\
\hline Admixture Dosage* & $1 \mathrm{X}$ & $1 \mathrm{X}$ & $1.5 \mathrm{X}$ & $1.0 \mathrm{X}$ & $1.0 \mathrm{X}$ & $1.0 \mathrm{X}$ & $1.0 \mathrm{X}$ \\
\hline Flow (inches) & 15 & 13.75 & 14.75 & 14.0 & 13.5 & 15.0 & 13.5 \\
\hline Bleed Water (mL after 24 hr) & none & none & none & $33 \mathrm{~mL}$ & none & $30 \mathrm{~mL}$ & none \\
\hline Compressive Strength (psi) & & & & & & & \\
\hline 14 days & 630 & & 890 & 955 & 1030 & 960 & 1080 \\
\hline 28 days & 1620 & 1813 & 1840 & 1740 & 1840 & 1710 & 1970 \\
\hline 90 days & 3465 & & 3300 & 3190 & 3220 & 2940 & 3590 \\
\hline Young's Modulus (psi) & $3.3 \mathrm{E}+05$ & -- & $3.0 \mathrm{E}+05$ & $3.2 \mathrm{E}+05$ & $3.2 \mathrm{E}+05$ & $2.9 \mathrm{E}+05$ & $3.3 \mathrm{E}+05$ \\
\hline Poisson's Ratio & & & 0.13 & 0.14 & 0.14 & 0.14 & 0.13 \\
\hline $\begin{array}{l}\text { Saturated Hydraulic } \\
\text { Conductivity (cm/sec) }\end{array}$ & $5.9 \mathrm{E}-08$ & & & & $4.3 \mathrm{E}-08$ & & \\
\hline
\end{tabular}

* The amount of the admixture blend relative to the reference blend is indicated. The reference blend contained 90 fluid ounces of ADVA Flow and 275 grams of Kelco-Crete.

Table 5-4. Physical Properties of the Capping Grouts (HRG9 and SRG9) Prepared in the BenchScale [9] and Scale-Up Tests.

\begin{tabular}{|c|c|c|c|c|c|c|c|c|}
\hline Property & $\begin{array}{l}\text { HRG9 } \\
\text { Bench }\end{array}$ & $\begin{array}{l}\text { SRG9 } \\
\text { Bench }\end{array}$ & $\begin{array}{c}\text { SRG9 } \\
\text { Truck } 3 \\
\end{array}$ & $\begin{array}{c}\text { SRG9 } \\
\text { Truck } 6 \\
\end{array}$ & \begin{tabular}{|c|} 
SRG9 \\
Truck 12 \\
\end{tabular} & $\begin{array}{c}\text { SRG9 } \\
\text { Truck } 13 \\
\end{array}$ & $\begin{array}{c}\text { SRG9 } \\
\text { Truck } 14 \\
\end{array}$ & $\begin{array}{c}\text { SRG9 } \\
\text { Truck } 15 \\
\end{array}$ \\
\hline Admixture Dosage* & $1 \mathrm{X}$ & $1 \mathrm{X}$ & $1.5 \mathrm{X}$ & $1.5 \mathrm{X}$ & $1 \mathrm{X}$ & $1 \mathrm{X}$ & $1 \mathrm{X}$ & 1.5 \\
\hline Flow (inches) & 15 & 13.5 & 14.25 & 14.25 & 12.5 & 13.5 & 13.0 & 11.0 \\
\hline Bleed Water (mL after $24 \mathrm{hr})$ & none & none & none & none & $70 \mathrm{~mL}$ & none & $34 \mathrm{~mL}$ & none \\
\hline \multicolumn{9}{|l|}{ Compressive Strength (psi) } \\
\hline 14 days (ave of 2 ) & 740 & 1250 & 1040 & 1030 & 1240 & 1100 & 1050 & 1560 \\
\hline 28 days (ave of 2 ) & 1940 & 2125 & 2105 & 2450 & 2500 & 2280 & 2170 & 2760 \\
\hline 90 days (ave of 2) & 3885 & 3665 & 3620 & 3530 & 4030 & 3820 & 3610 & 4140 \\
\hline Young's Modulus (psi) & $3.6 \mathrm{E}+05$ & $3.7 \mathrm{E}+05$ & $3.4 \mathrm{E}+05$ & $3.0 \mathrm{E}+05$ & $3.7 \mathrm{E}+05$ & -- & -- & -- \\
\hline Poisson's Ratio & & & 0.25 & 0.17 & 0.13 & -- & -- & -- \\
\hline $\begin{array}{l}\text { Saturated Hydraulic } \\
\text { Conductivity }(\mathrm{cm} / \mathrm{sec})\end{array}$ & 3.8 E-08 & & $3.0 \mathrm{E}-08$ & & & & & \\
\hline
\end{tabular}

* The amount of the admixture blend relative to the reference blend is indicated. The reference blend contained 90 fluid ounces of ADVA Flow and 275 grams of Kelco-Crete. 


\subsection{Flow and Placement Rate}

One objective of the scale-up testing was to evaluate the flowability of the Stabilizing, Structural, and Capping grouts designed in the bench-scale testing. Grout flow was tested using the 80-foot long trenches. Four pours were made into the end of the trenches directly from the concrete truck. These tests successfully demonstrated flow of all three grouts over 75 feet to produce a relatively level surface. Placement rates for these pours were high (about 340 to $500 \mathrm{cyd} / \mathrm{hr}$ ).

Two additional pours were pumped about 250 feet through a 5-inch slick line at lower placement rates (about $70 \mathrm{cyd} / \mathrm{hr}$ ). The pump on the boom truck was used. A flow of 75 feet was achieved for the first placement, but the grout was not self-leveling. The difference in elevation at the opposite ends of the trench was about 11 inches. The pour thickness was 14 inches at one end and 3 inches at the opposite end. This is a significant difference since a self-leveling placement of 5 cyd should yield a grout layer of 8-inch thickness.

The second pumped placement was made near the center of the trench onto the sloped layer of grout resulting from the first pour. The placement rate was about $70 \mathrm{cyd} / \mathrm{hr}$. The placement was made onto this sloping surface (11-inch depth difference between ends). The sloped surface enhanced flow along the down-slope and the difference in height at the two ends of the trench had been reduced to about 3 inches

Testing was not performed for an end placement at a low pour rate onto a sloped grout layer. Additionally testing was not performed to mimic a continuous pour from the end of a trench to determine whether the significant sloping observed with the first placement would diminish with continued grout placement.

The scale-up test results for the trench placements indicate that high placement rates of (about 400 or more cyd/hr) are required to achieve flow 70 feet which is required if a near-edge riser is used to fill a large HLW tank. Since the maximum placement rate achieved at Savannah River during Closure of Tanks 17 and 20 (80 feet in diameter) was $80 \mathrm{cyd} / \mathrm{hr}$, filling large tanks from a single near-edge riser with the current grout formulations is not recommended. High production and placement rates require risers sized to accommodate the throughput.

The scale-up testing indicated that at placement made at about $70 \mathrm{cyd} / \mathrm{hr}$ flowed and self-leveled over 40 feet. Consequently, a central riser or multiple near-edge risers (at least two at opposite sides of the tank) can be used to fill the large Hanford HLW tanks. This is consistent with the observations made during SRS Tanks 17-F and 20-F closure.

\subsection{Grout Placement through a Tremie}

Grout placement through a tremie was successfully demonstrated using an SRG9 capping grout mix. A flexible tremie hose can be cut to an appropriate length and attached to the end of a slick line. The tremie can be introduced into a riser such that the drop height of the grout is controlled to minimize segregation of the pour stream. The flexible tremie can be cut after each production run and dropped into the tank to reduce handling and the potential for spreading contamination 
outside of the tank. Grout drop heights of two to ten feet are recommended based on SRS experience. The results obtained in these experiments are consistent with observations made while closing SRS Tanks 17-F and 20-F and can be applied to each of the three grouts used in the Hanford closure concept.

\subsection{Submerged Grout Placement}

Placements to evaluate the effect of pumping against an eight-foot grout head were made in two vertical culverts 8 feet tall and 2 feet in diameter. This test is relevant to dome filling. Capping Grout was pumped into the bottom of each culvert through a slick line until they were filled. The purpose of these tests was to demonstrate that grout can be placed from a near edge riser at a submerged location below the top of the tank dome and still fill the dome.

The first placement filled the culvert with grout, at which time the pump was turned off. Approximately 9-10 inches (10 to $11 \%$ of the volume placed in the form) of bleed water formed on top of the placement indicating excessive segregation. The Capping Grout used for this test was from the same batch used for the concrete vibration testing. This batch of SRG9, as previously explained, was a mix that displayed a slight amount of bleed water. Although this high water content of the mix contributed to the segregation observed in the culvert, agitation caused by escaping air introduced by the pumping action was the main cause of the problem. The mix appeared to "boil" as it rose up in the culvert.

A second placement was made using a new batch of the Capping Grout, SRG9, which was modified to be more cohesive (1.5 times the admixture and less water). This mix had a low ASTM D-6103 flow of 11 inches. Segregation and bleed water were completely eliminated in this placement which also was made under about 8 feet of grout head pressure.

These results indicate that at higher admixture and lower water amounts, the Capping Grout, SRG9, can be pumped into the dome region of a tank through a side riser. Multiple near-edge risers are recommended for filling the dome of an 80 foot HLW tank in this manner.

A tradeoff exists between flow and segregation. If a highly flowable grout is required (as e.g., through a near edge riser), then segregation may occur. On the other hand, if the capping grout is placed through a center riser or through several near edge risers, then a grout with a lower flow may be used. Further experimentation will be required to determine the optimal amounts of water and admixture for each scenario.

\subsection{Grout Segregation}

One objective of the scale-up testing was to evaluate the potential for segregation in the three grouts designed in the bench-scale testing. The Capping grout was selected. A test was performed in which SRG9 was dropped from a height of ten feet into Trench 3 to determine whether segregation (separation of the water as bleed water) would occur. Bleed water was observed in the trench; however, samples taken from the truck and transported to N-area also had bleed water. The segregation was most likely due to the properties of the mix itself rather than to pour stream separation as the result of the 10 feet drop. 
A test was also performed to determine whether a concrete vibrator would enhance flow without leading to segregation. The grout was placed in the end of Trench 3 through a slick line at ground level. The Capping Grout, SRG9, which had bleed water in the test cylinders, was used. Bleed water appeared immediately after the vibrator was turned on and increased as a direct effect of vibration. In addition, the vibrator was not effective in significantly enhancing the flow and self-leveling properties of the tank fill grout. Consequently vibration of grouts with 13.5 to 15 inch flows is not recommended. It is not known whether vibration will enhance flow without segregation when applied to "thicker" grouts, i.e., less flow per ASTM D-6103.

\subsection{Heel Interaction with Grout}

Pieces of scrap metal to simulate equipment, various sized solids simulating agglomerated sludge, aluminum hydroxide precipitate simulating sludge particles, and liquid simulant were placed in the swimming pools prior to placement of the grout. The purpose of these tests was to determine the interactions that occur between the grout and tank heel and debris components.

The upward displacement of the liquid simulant has been discussed in Section 5.3. The liquid phase, unless bound by a top dress layer, will migrate to the top of the newly poured grout layer. This was demonstrated for both the C-106 heel simulant (Swimming Pool 1) and the C-200 heel simulant (Swimming Pool 2).

Simulated equipment and debris on the bottom of the pools were covered or encapsulated by the structural grout placement. The grout filled the small crevices and openings in of the equipment and debris. This demonstrates that grouts designed for tank closure will not only flow around and encapsulate equipment left in the tank but can also flow into the small voids in the debris.

A variety of solids with different particle sizes were placed around the bottom of the swimming pool forms. For Swimming Pool 2, solids were also introduced with the C-200 simulant (white, very fine precipitated aluminum hydroxides). These white aluminum hydroxide particles from the C-200 simulant moved outward toward the edges of the tank as the stabilizing layer was introduced. Observation of the bottom of the stabilizing grout after one week of curing demonstrated that the particles were isolated and covered by the grout. (The bottom surface of the cured grout was white in the places where the aluminum hydroxide solids were covered over.) Aluminum hydroxide particles directly under the pour stream were not observed and were presumed to be mixed with the Stabilization grout as the result of the force from the initial impact of the dropped grout.

The sand size particles near the edges of the pools were also covered, but not encapsulated (surrounded). As with the fine white aluminum hydroxide particles, the grout was unable to penetrate the interstitial regions of the fine particulates and simply flowed over the top of these piles. This resulted in isolating the simulated sludge by sandwiching it between the bottom of the swimming pool and the first grout layer.

The grout was able to penetrate the interstitial regions of the coarser particles (3/4 inch granite gravel) and encapsulate them. Only those particles touching the bottom of the pool may not have been completely surrounded/encapsulated. 
These results are important for determining a strategy for filling the tanks. This includes determining the order for wet and dry grout placements. One option is to fix the liquid and solid portions of the heel at the bottom of the tanks by applying and initial top dressing followed by a stabilization grout placement. The second option is to place the stabilization grout over the solid portion of the tank heel and solidify/fix the liquid portion of the heel between the two layers of the Stabilization Grout or between the Stabilization Grout and the Structural Grout.

The placement of a grout layer first would essentially isolate all the sludge particulates, encapsulate and fill void spaces within equipment at the bottom, and encapsulate sludge particles with a size greater than about $1 / 2$ inch in size. A grout placement first would also displace the supernate to a higher location in the tank thus providing the opportunity of top dressing the supernate at a location of choice. This would sandwich the top dressed supernate between two layers of stabilization grout rather than at the bottom tank surface.

Applying top dressing would solidify some or all (depending upon the amount of top dressing introduced) of the liquid supernate at the bottom of the tank. It would also coat equipment and sludge particles not in contact with the supernate. A subsequent placement of grout would then result in a layered structure consisting of tank bottom-sludge particle-powdered top dressingStabilization Grout.

\subsection{Top Dressing and Liquid Simulant Migration}

Swimming Pool 1 form contained approximately 150 gallons of liquid Tank C-106 simulant. This amount of liquid has a mass of 1,250 pounds and formed a layer about 1.6 inches deep in the bottom of the pool. The liquid depth in Tank C-106 is reported to be less than that simulated in the test pool. However, the pool test provided clear evidence as to the interaction of the supernate during the grout pours and top dressing applications.

During pouring, the grout flowed under the liquid simulant and displaced it to the top of the newly formed grout surface. Therefore, without top dressing the liquid simulant, the supernate will migrate to the top surface of the each grout layer. Since some of the radionuclides of concern are present in the supernate, this process will move the radionuclides closer to the tank roof.

During the scale-up testing, dry grout was applied in two separate top dressings. The first was conducted after the initial layer of stabilizing grout was placed. An insufficient amount of top dressing was applied and a significant amount of liquid simulant remained after this first placement. Addition of a second stabilizing layer resulted in the migration of the liquid simulant to the top surface. A second and final top dressing was then applied which removed most, but not all of the liquid supernate. Subsequent placements of structural and capping grouts were made and the liquid simulant continued to be displaced to the top surface.

During filling of Tank C-106, or any other HLW tank containing supernate, a strategy will be required to determine when and how much dry grout should be applied. One strategy is to first place a stabilization grout layer in the tank, followed by top dressing to completely sorb all the liquid, then followed by another layer of stabilization grout. Such a strategy will lead to 
confinement of the supernate radionuclides between two separate layers of stabilization grout. An alternative strategy is to perform several partial top dressings, alternating with layers of stabilization grout. The grout/top-dress, grout/top-dress strategy was demonstrated in the scaleup testing.

Visual observation of the pool 12 hours after the top dressing was completed indicated that the sprayed powder effectively and uniformly coated the surface of the grout as well as the walls of the pool and hut. Since the chemistry of the top dress powder is the same as the Stabilization Grout binder, any soluble Tc-99 on the tank wall will immobilized by the same reactions as in the grout itself [8].

The amount of top dressing required to sufficiently bind/react with all of the liquid simulant was roughly estimated during the field-testing. Addition of top dressing having a mass of about 1.5 times the mass of the liquid portion of the simulant resulted in the complete uptake of the liquid. Adjustments in the amount of top dressing required during actual tank filling will have to be made to account for deposition on the tank wall and equipment, for uneven placement, and for uncertainties in the amount of liquid present in the tank.

\subsection{Grout Interfacial Regions}

The scale-up testing provided the opportunity to evaluate the interfacial regions between grout placements and between grout and top dressing placements. The layering was visually observed in the monoliths poured in the trench forms. The layering was expressed as very slight color differences between the three pours. Fracturing along the grout layer interfaces was not characteristic for the trench pours. During excavation (5-10 days after the final pours) the trench monoliths were broken into large blocks perpendicular to the long axis of the trench. The trenches did not contain any simulated heel supernate, the amount of segregation for these pours nil, and the time between pours was a few hours to one day. Consequently, bonding between the layers was not compromised.

Three grout placements were made in Swimming Pool 2 which contained simulated C-200 simulated heel (high caustic sodium salt supernate and aluminum hydroxide precipitate). The time intervals between placements of the three grout layers are shown in Table 5-5. The swimming pool form was dismantled and the layered grout monolith was demolished eight days (192 hours) after placing the first grout layer, Stabilization Grout.

Table 5-5. Times Between Pours in Swimming Pool 2 (no dry grout addition).

\begin{tabular}{|l|c|c|}
\hline Layer & Time From First Pour (hr) & Time Between Pours (hr) \\
\hline Stabilization & 0 & 0 \\
\hline Structural & 21 & 21 \\
\hline Capping & 120 & 99 \\
\hline
\end{tabular}

A Caterpillar dozer was used to break up the monolith. In the process, the dozer and a heavy duty forklift unsuccessfully attempted to break the monolith by lifting and dropping it 6 feet. The dozer also tried to flip the monolith over. The monolith withstood the assault by the dozer and forklift/front end loader and remained intact. Finally the dozer rammed its blade near the 
Stabilization and Structural Grout interface on the side of the monolith, and the monolith broke along the interfacial plane. During this process the bottom layer also cracked vertically through the layer. The force and effort necessary to break the monolith demonstrates the structural strength of layers themselves, as well as the bonding between layers.

Four grout placements and two dry grout placements were made in Swimming Pool 1 which contained 150 gallons of simulated Tank C-106 heel (sodium oxalate and sodium nitrate solution). The times between placements are summarized in Table 5-6.

Table 5-6. Times Between Placements in Swimming Pool 1.

\begin{tabular}{|l|c|c|}
\hline Layer & Time From First Pour (hr) & Time Between Pours (hr) \\
\hline First Stabilization & 0 & 0 \\
\hline First Top Dressing & 2 & - \\
\hline Second Stabilization & 21 & 19 from $1^{\text {st }}$ top dressing \\
\hline Second Top Dressing & 24 & - \\
\hline Structural & 44 & 20 from $2^{\text {nd }}$ top dressing \\
\hline Capping & 143 & 99 \\
\hline
\end{tabular}

From the experience gained in breaking apart Swimming Pool 2, the dozer was able to separate the pool 1 monolith by ramming it at the second dry grout top-dressed layer between the second stabilization layer and the structural layer. The clean break produced two essentially flat surfaces (top of the second stabilization layer and the bottom of the structural layer) although the top portion of the monolith cracked vertically during this operation. The total time between the first grout placement and the final destruction of the monolith was 9 days (216 hours). As was observed with Swimming Pool 2, the monolith from Swimming Pool 1 was remarkably resilient and structurally coherent even at short curing times. The strength of the grouts in the layers and the layer-to-layer bond strength will continue to increase significantly with time.

\subsection{Equipment and Riser Filling}

Filling the 1-inch diameter PVC pipes with cable grouts demonstrated that commercially available grouts can be used for stabilizing equipment left in the tanks by filling the internal void spaces, provided that access from the tank top is available. The selection of a particular cable grout will depend on the field conditions for the equipment that requires filling.

The testing demonstrated that a vertical 1-inch pipe 20 feet long can be easily filled either by gravity pouring from the top or from the bottom up by pumping the grout through a tube inserted to within a few inches of the bottom of the pipe. Dissection of pipes indicated that filling was complete and that even small obstructions (electrical wires) were completely encapsulated in grout.

These experiments were designed to demonstrate the feasibility of filling equipment left in place in the Hanford HLW tanks. Additional design and testing using more realistic equipment and riser configurations is recommended to implement the concept. 


\subsection{CONCLUSIONS}

The scale-up testing was performed over two weeks and included grout placements in three trenches ( $80 \mathrm{ft}$ long), two swimming pools (14 ft in diameter), and two culverts ( $2 \mathrm{ft}$ in diameter and $10 \mathrm{ft}$ tall). Placements of the three grout mixes (stabilization, structural, and capping) were accomplished either directly from the cement truck or through transfer of the load to a pump and slick line with and without a tremie. Two placements of top dressing were also performed within a closed hut over one of the swimming pools. Finally, testing of three cable grouts to fill $20-\mathrm{ft}$ sections of 1-in diameter rigid tubing was performed to simulate the filling of equipment left in the tank. A video documenting the scale-up testing is provided elsewhere [10].

The following conclusions were made as a result of this testing:

- At placement rates between 340 and $500 \mathrm{cyd} / \mathrm{hr}$, the tanks fills/grouts flowed 75 feet and were self-leveling in the 80-foot trenches.

- At placement rates between 60 and $80 \mathrm{cyd} / \mathrm{hr}$, the grouts still flowed 75 feet but were not self-leveling.

- Placing grout onto a sloped surface enhanced flow in the down slope direction.

- Grout production at a remote location and delivery in a concrete truck required final formulation adjustment (adding water and/or admixture) at the field site to ensure the proper grout flow.

- The compositional variabilities for all of the solid ingredients in each of the fifteen grout batches prepared for the scale-up testing by Lafarge Ready Mix were acceptable according to ACI 304R Manual of Concrete Practice.

- Nine percent less water on average was required for mixes prepared in the scale-up test compared to equivalent (same admixture dosage) mixes prepared in the bench scale study.

- The use of 1.5 times the design amount of admixture in selected mixes to provide better control of bleed water.

- Mixes with extra admixture (1.5 times the design amount of admixture), required extra water ( $4 \%$ more water on average) compared to the amount determined from the bench-scale study.

- Top dressing with a mixture of dry grout binder ingredients was effective in solidifying the supernate.

- The top dressing materials coated all inner surfaces during the application. Application of top dressing in Hanford HLW tanks will result in coating the inner walls and equipment with the binder powder (cement, slag, and fly ash).

- The dust generated during the placement of the top dressing settled within 12 hours in the scale-up test.

- Finer particles of sludge near the edges of the swimming pool test form were covered, but not encapsulated by the placed grout. The fine sludge particles directly under the discharge were mixed into the grout. Consequently, the fine sludge particles within an actual HLW tank will either be sandwiched between the tank bottom and the first layer of grout or be mixed into the Stabilization grout.

- Coarser particles of sludge were covered and/or encapsulated by the placed grout as the Stabilization layer grout flowed between the interstitial regions of coarse material fixing it in place on the bottom of the form.

- The liquid simulant was displaced upward as the denser tank fill grouts flowed under the supernate. The grouts rolled up along the side of the form creating a ring of supernate 
several inches in form the side-walls of the pools. The supernate continued to be displaced towards the top of the form with the placement of each successive grout layer.

- Dry grout top dressing was successfully used to immobilize the supernate (and therefore, soluble Tc-99) near the bottom of the form. Dry grout can be added at any location above the bottom of the tank by controlling the time of application of top dressing(s).

- Introducing grout into the tank from 10 plus feet above tank or grout level may lead to segregation. Additional admixture and/or less water are recommended to control segregation provided acceptable flow is maintained.

- Vibration to enhance flow caused segregation (bleed water) in the tank fill grouts. These grouts are not concrete and do not respond to vibration in the same manner as low slump concrete.

- Tremie placement was demonstrated and is recommended to achieve acceptable drop heights inside the high level waste tanks.

- Pumping Capping Grout against a head of up to 8 feet was demonstrated. However, extra admixture (up to $1.5 \mathrm{X}$ ) and less water may be necessary to eliminate segregation under the same conditions.

- The placements made in each of the forms resulted in layered monolithic structures that were difficult to separate along the interfacial pour layers and to crack in other directions even at very early stages of curing (5-10 days). A dozer and heavy duty forklift were required to break up the monoliths.

- The layered monoliths will get stronger as the result of longer cure times as indicated by the significant strength gain in the scale-up samples collected in the field and analyzed in the laboratory at various curing times up to 90 days.

- The first fractures that developed in the swimming pool monoliths were through the dry grout layer (pool 1) and between the Stabilization and Structural layer (pool 2) where the displaced supernate was concentrated.

- Commercially available cable grouts were successfully demonstrated for filling risers and equipment left in the tank. Placement of the cable grouts by gravity filling a 1-inch vertical PVC pipe and by pumping through a $3 / 8$ inch tube was demonstrated. Both techniques have applicability for filling tank equipment and risers. 


\subsection{RECOMMENDATIONS}

The following recommendations are based on the scale-up test results:

- Grout placement from a center riser is recommended for filling large HLW tanks (80 feet in diameter). Multiple near-edge risers (at least two) may provide acceptable access for grout placement if the risers are large enough to achieve high flow rates and are at opposite sides of a tank. (The high flow rates tested in the scale-up effort were about greater than $300 \mathrm{cyds} / \mathrm{hr}$.)

- Flow and bleed water determinations should be performed frequently under full-scale batching and placement conditions and kept within specifications by adjusting the water and admixture dosage.

- The grout drop height in the HLW tanks should be limited to about 10 feet to prevent segregation of the flow stream. Placement via a tremie attached to a slick line was demonstrated in the scale-up testing.

- The option of placing dry grout top dressing to solidify the liquid portion of the heel or inadvertent bleed water should be included in the closure design. Dry grout top dressing provides a means of preventing the supernate liquid from rising in the tank.

- Commercially available cable grouts or similar formulations can be used to fill risers and small voids in equipment left in the tanks. Placement via gravity filling or pumping through a rigid tube $3 / 8$ inch in diameter was demonstrated.

- The three Hanford tank closure grouts should be batched with Hanford ingredients at the 8-10 cubic yard scale to confirm the water and admixture dosage requirements. This testing is necessary to ensure that mixes can be produced with the proper flow and physical properties within the limits of water and admixture identified in the specifications.

- The use of vibration to enhance flow is not recommended since it causes segregation (bleed water) in the tank fill grouts. These grouts are not concrete and do not respond to vibration in the same manner as low slump concrete.

\subsection{QUALITY ASSURANCE}

Calibrated equipment and test instruments were used to perform the work described in this report. The program was performed in accordance with the SRTC Conduct of Research and Development Manual and results were recorded in SRS Laboratory Notebook WSRC-NB-200300191 and WSRC-NB-2003-00192. 


\subsection{REFERENCES}

1. RPP-14590, Rev. 0. Engineering Report for Interim Closure of Tank 241-C-106 and the 241-C Farm 200-Series Tanks, CH2M HILL, Hanford Group, Inc., Richland, WA, February $11,2003$.

2. RPP-16795, Rev. 0. Engineering Evaluation of Interim Isolation of Hanford Single Shell Tanks, CH2M HILL, Hanford Group, Inc., Richland, WA, July 11, 2003.

3. Interoffice Work Order (IWO) No. MOSRLE81 from Richland Operations Office, February 24, 2003.

4. WSRC-RP-2003-00515, Rev. 0. ATCD Project Grout Design and Testing Scale-Up Task Technical and QA Plan, C. A. Langton, Savannah River Technology Center, Westinghouse Savannah River Company, Aiken, SC, August 20, 2003.

5. SRT-ITB-2003-00060, Rev. 1. Selection of Grout Mix Designs and Materials for Hanford Tank Closure Scale-Up Testing, T. H. Lorier, J. R. Harbour, C. A. Langton, Savannah River Technology Center, Westinghouse Savannah River Company, Aiken, SC, February 12, 2004.

6. J. E. Laurenz and R. B. Calmus, Personal Communication, July 2003.

7. J. E. Laurenz, Personal Communication, July 2003.

8. WSRC-TR-2004-00021, Rev. 0. Stabilizing Grout Compatibility Study, J. R. Harbour, T. B. Edwards, T. H. Lorier, and C. A. Langton, Westinghouse Savannah River Company, Savannah River Technology Center, Aiken, SC 29808 and R. C. Moore, J. L. Krumhansl, K. C. Holt, F. Salas, and C. A. Sanchez, Sandia National Laboratory, Albuquerque, NM , January 12, 2004.

9. WSRC-TR-2003-00447, Rev. 0. Grout Formulations for Closing Hanford High-Level Waste Tanks - Bench-Scale Study, T. H. Lorier, D. H. Miller, J. R. Harbour, C. A. Langton, Westinghouse Savannah River Company, Savannah River Technology Center, and W. L. Mhyre, Washington Group International, Quality Programs and Environmental Sciences, Aiken SC, 29808, September 30, 2003.

10. WSRC-MM-2004-00027. J. L. Siler, C. A. Langton, J. R. Harbour, D. H. Miller, Hanford Tank Closure Grout Scale-Up Test, Savannah River National Laboratory, Westinghouse Savannah River Company, Aiken, SC, July 6, 2004.

11. WSRC-RP-2003-01128. C. A. Langton and J. R. Harbour, Hanford Grout Specifications for High-Level Waste Tank Closure. 


\section{ASTM REFERENCES}

ASTM C 33-03. "Standard Specification for Concrete Aggregates," American Society for Testing and Materials, Philadelphia PA.

ASTM C 128-01. "Standard Test Method for Density, Relative Density (Specific Gravity), and Absorption of Fine Aggregate," American Society for Testing and Materials, Philadelphia PA.

ASTM C 136-01. "Standard Test Method for Sieve Analysis of Fine and Coarse Aggregates," American Society for Testing and Materials, Philadelphia PA.

ASTM C 138-01. "Standard Test Method for Density (Unit Weight), Yield, and Air Content (Gravimetric) of Concrete," American Society for Testing and Materials, Philadelphia PA.

ASTM C 150-89, "Standard Specification for Portland cement," Annual Book of ASTM Standards Section 4 Construction, Vol. 04.02, Concrete and Aggregates, American Society for Testing and Materials, Philadelphia PA.

ASTM C 215-02. "Standard Test Method for Fundamental Transverse, Longitudinal, and Torsional Resonant Frequencies of Concrete Specimens," American Society for Testing and Materials, Philadelphia PA.

ASTM C 231-97. "Standard Test Method for Air Content of Freshly Mixed Concrete by the Pressure Method," American Society for Testing and Materials, Philadelphia PA.

ASTM C 232-9. "Standard Test Methods for Bleeding of Concrete," American Society for Testing and Materials, Philadelphia PA.

ASTM C 403-99. "Test Method for Time of Setting of Concrete Mixtures by Penetration Resistance," American Society for Testing and Materials, Philadelphia PA.

ASTM C 469-02. "Standard Test Method for Static Modulus of Elasticity and Poisson's Ratio of Concrete in Compression," American Society for Testing and Materials, Philadelphia PA.

ASTM C 494-99. "Standard Specification for Chemical Admixtures for Concrete," American Society for Testing and Materials, Philadelphia PA.

ASTM C 618-92. "Standard Specification for Fly Ash and Raw or Calcined Natural Pozzolans for Use as a Mineral Admixture in Portland Cement Concrete," Annual Book of ASTM Standards Section 4 Construction, Vol. 04.02, Concrete and Aggregates, American Society for Testing and Materials, Philadelphia, PA.

ASTM C939-87. "Standard Test Method for Flow of Grout for Preplaced-Aggregate Concrete (Flow Cone Method)," Book of ASTM Standards Section 4 Construction, Vol. 04.02, Concrete and Aggregates, American Society for Testing and Materials, Philadelphia PA.

ASTM C 989-89. "Specification for Ground Granulated Blast-Furnace Slag for Use in Concrete and Mortars," Annual Book of ASTM Standards Section 4 Construction, Vol. 04.02, Concrete and Aggregates, American Society for Testing and Materials, Philadelphia PA.

ASTM D 6103-97. "Standard Test Method for Flow Consistency of Controlled Low Strength Material (CLSM)," American Society for Testing and Materials, Philadelphia , PA. 